\title{
Madalyonun 'Öteki' Yüzü: Görünür Göçmenlerin/Yabancıların Toplumsal ve Kurumsal Adalet Algıları (Yalova İli Örneği)
}

\section{The Other Side of the Coin: Perception of Social and Institutional Justice of Visible Immigrants / Foreigners (Yalova City Example)}

\author{
Muhammed Ferit Duman ${ }^{\mathrm{a}, *}$ \\ a Dr. Öğr. Üyesi, Bandırma Onyedi Eylül Üniversitesi, Sağlık Hizmetleri MYO, Sosyal Hizmet ve Danıșmanlık Bölümü, 12100, Balıkesir/Türkiye. \\ ORCID: 0000-0002-7590-5600
}

\section{MAKALE BİLGISİ}

Makale Geçmişi:

Başvuru tarihi: 17 Kasım 2019

Düzeltme tarihi: 03 Şubat 2020

Kabul tarihi: 17 Subat 2020

\section{Anahtar Kelimeler:}

Adalet,

Göç,

Göç Yönetimi,

Göçmen,

Suç,

Uluslararası Göç

\section{A R T ICLE INFO}

Article history:

Received 17 November 2019

Received in revised form 03 February 2020

Accepted 17 February 2020

Keywords:
Crime
International Migration
Justice
Migrant
Migration
Migration Management

ÖZ

Dünyada alışılageldik göç tüm bağlamları ile nitelik değiştirmekte ve uluslararası boyutta giderek artan bir hacimde görünürlük kazanmaktadır. Bu durum göçe en aşina ve hazır ülkelerin bile dayanıklılığını zorlarken Türkiye gibi göç güzergâhında olan bir ülkeyi sinir uçlarından etkilemektedir. Türkiye devleti ve toplumu, Osmanlı bakiyesi topraklardan gelmeleri teşvik edilen, intikalleri sonrasında resmi bir organizasyon ile iskân edilen ve topluma zaten büyük oranda entegre oldukları için 'görünmeyen' göçmen kitleleri tarafından demografik olarak beslendiği için uluslararası göç olgusuna oldukça aşinadır. Gelinen noktada yabancılar toplumsal gündelik hayatın ve kurumsal sistemin aktif bir bileșeni haline gelmiștir. Bu anlamda kurumları/devleti ve toplumu düzende tutan adalet, göç yönetiminin de en önemli unsuru olarak öne çıkmaktadır. Dolayısı ile kitleselleşen yabancı/görünür göçmenlerin profilleri, toplumsal ve kurumsal adalet algıları en az ev sahibi toplumunkiler kadar önem arz eder durumdadır. Makale çalışmasında Yalova ilinde bulunan 450 yabancı uyruklu şahıs ile yabancıların yoğun olduğu yerlerde, kat1 yapılandırılmış görüşme biçiminde (yaklaşık 40 günde) gerçekleştirilen, anket ve gözlem verileri üzerinden yabancıların profillerine, toplumsal ve kurumsal adalet algılarına, alacakları tutumlara ilişkin veriler değerlendirilmiștir.

\section{A B S T R A C T}

The usual migration in the world is changing its quality in all its contexts and gaining an increasing volume of international visibility. This situation forces even the most prepared countries to resist immigration. It affects nerve endings of Turkey, which is in the intersection of migration routes. Because of the Turkish Society has been fed with the majorly integrated 'invisible' migrant people who were encouraged to migrate to Anatolia from ottoman legacy lands and settled down by governmental organizations, Turkish state and Society got used to the international migration phenomena. At this point, foreigners have become an active component of everyday life and institutional system. In this sense, justice, which keeps the institutions / state and society in order, stands out as the most important element of migration management. Therefore, the profiles of mass foreign / visible migrants, and their perceptions of social and institutional justice are just as important as those of the host society. In this article, 450 foreign nationals in Yalova province and the foreigners profiles, perceptions of social and institutional justice, their attitudes towards social and institutional justice were evaluated through strictly structured interviews (conducted in approximately 40 days)in the areas of foreigners.

\section{Giriş}

Göç insanların tarih boyunca en alışageldikleri kavramlardan biri olsa bile insanlığın tarihi serüveni içinde yeniden ve yeniden anlam kazanmıştır. Günümüzde ise çevresel ve ekonomik bozulma ve cazibelerin, ittiği ve çektiği alışılageldik göç bağlamlarına, toplumsal bozulma ve düzenin, ittiği ve çektiği göç bağlamları da eklenmektedir. $\mathrm{Bu}$ durum uluslararası göçü her

\footnotetext{
* Sorumlu yazar/Corresponding author.

e-posta: mferitduman.fd@gmail.com
} 
zamankinden daha görünür ve hissedilir kılmakta ve göç yönetimini karmaşıklaştırmakta, zorlaştırmaktadır.

Göçün toplumsal bağlamının bu denli etkili olması göçmenleri menşe ülkeleri üzerinden tanımlamak yerine göçmenlerin ev sahibi toplum tarafından nasıl algılandıkları üzerinden tanımlanmalarını gerekli kılmaktadır. Artık ev sahibi toplumlar kendi kültür havzası içinde olduklarına inandıkları kişi ve grupları yabancı/göçmen olarak görmemektedir. Bu tip kişi ve gruplar hukuki statüsü ve menşe ülkesi bakımından göçmen olarak nitelendirilebilecek olsalar bile ev sahibi toplumca, sosyolojik olarak vatandaş gibi makbul kabul edilmektedir. Fakat ortak kültürü paylaşmayanlar ise hukuki statüleri bakımından vatandaş olsalar bile sosyolojik olarak yabancı görülmekte hatta kendilerinden, diğer göçmenlerden daha fazla uyum sağlamaları beklenmektedir.

$\mathrm{Bu}$ durum ise göçmenlere, menşe ülkeleri üzerinden değil ev sahibi toplum içindeki görünürlük ve görünmezlik halleri/algıları üzerinden statü ve rol kazandırmaktadır. Ayrıca göçün, yoğunluğu, hızı, göç edenlerin profilleri, göçmenlerin etnik cemaat veya azınlık olmayı başarabilmeleri, göçmenlerin sosyal ve kültürel bozulmanın sebebi olması veya algılanması gibi faktörlerin/değişkenlerin, göç yönetimi tarafından idare edilememesi durumunda, toplum içinde y1kıcı göçmenler algısı/kategorisi oluşabilmektedir. Görünür göçmenin yıkıcı göçmen kategorisine/algısına dönüşmemesi (dönüşmesi halinde oluşacak toplumsal krizin yönetilebilmesi) ancak meşru düzenleyici sistem olan adaletin toplumsal ve kurumsal bağlamalarının göç yönetiminde etkin biçimde kullanılması ile mümkün olacaktır. Yıkıcı olabilecek göç dalgalarına karşı toplumsal ve kurumsal dayanıklılık ancak toplumsal ve kurumsal adaletle sağlanabilecektir.

Özellikle suç sosyolojisi bağlamından bakıldığında bireysel veya toplumsal bir çıkar çatışmasında, temelde, olayın en az iki tarafı bulunmaktadır ve çatışmaya konu olayın adil çözümünde biri diğerinden daha ayrıcalıklı değildir. Bu çalışmada ise madalyonun 'öteki' tarafina yani dış göçle Türkiye'ye gelen ve 'yabanc1' olarak 'görülen' insanlara odaklanılmış, onların toplumsal adalete, adli kurumlara ve adli sürece ilişkin algıları, yaşayabilecekleri çıkar çatışmalarındaki muhtemel davranış biçimleri anlaşılmaya çalışılmıştır.

Çalışma 20 farklı ülkeden 450 katılımcı ile yaklaşık 40 günde, yabanc1/görünür göçmenlerin yaşam alanlarında, temel olarak anket tali olarak gözlem ve görüşme yöntemi ile toplanilan verilerden ve çaprazlanan verilerin değerlendirmelerinden oluşmaktadır.

Böylelikle yabanc1/görünür göçmenlerin; i)profillerine ilişkin veriler 16 soru (ülkesi, cinsiyeti, yaşı, işi, eğilim durumu, aylık geliri, evlilik durumu, eşlilik durumu, çocuk sayıları, Türkçe okuma, yazma, duyulanı anlama, konuşma becerileri, Türkiye'de kalma süreleri, Türkiye'de değiştirdikleri il sayısı adli birimlerle-kolluk, savcılık, mahkeme-deneyim durumları), ii) kurumsal adalet algılarına ilişkin veriler 12 soru, iii) toplumsal adalet algılarına ilişkin veriler 4 soru üzerinden detaylı bir biçimde anlaşılmaya çalışılmıştır. Ayrıca anket verileri kendi aralarında anlamlı biçimde çaprazlanarak; i)örneklem verilerinin değerlendirilmesi, ii) kurumsal adalet algılarına ilişkin verilerinin değerlendirilmesi (adli birimlerde kendini ifade edebilme eğilimlerinin değerlendirilmesi, adli sürece güven eğilimlerinin değerlendirilmesi, yakalanma endişelerinin değerlendirilmesi) ve iii) toplumsal adalet algılarına ilişkin verilerin değerlendirilmesi yapılmıştır.

\section{Göç ve Uluslararası Göç}

Süresi, yapısı ve nedeni ne olursa olsun insanların yer değiştirdiği nüfus hareketleri (Perruchoud ve Redpath, 2013, s.55) olarak tanımlandığında göç, insanın en doğal davranış biçimlerinden birisidir. Öyle ki, beşeri bilimler, prensipte, insanların bir 'göçmen tür' olduğunu doğrulamıştır (Massey vd., 1998, s.1). Dolayısı ile en yalın anlamı ile göç tarihini, Afrika Rift Vadisi'ndeki insanlığın kökeni ile başlatmak (Koser, 2007,s.1)mümkündür. Göç, türümüzün ortaya çıkışından bu yana insan toplumlarının gelişimiyle bütünleşmiş ve zamanla çeşitli toplumların ekonomik, etnik ve politik dinamiklerini sürekli olarak yeniden şekillendirmiştir (Baker ve Tsuda, 2015,s.3).

Göçün çok uzak geçmişten günümüze kadar insan ve doğanın dinamizmi içinde yeniden ve yeniden şekillenmesi ve kendisinin de topluma ve doğaya biçim vermesi, göçün (dolayısı ile göçmenin) anlamını tüm yönleri ile tanımlayacak bir kavramda uzlaşılmasına müsaade etmemektedir. Uluslararası Göç Örgütü bile uluslararası düzeyde, 'göçmen' için evrensel olarak kabul edilmiş bir tanımın olmadığını ve mevcut tanımın', UGÖ (İOM) tarafından kendi amaçları için geliştirildiğini ve herhangi bir yeni yasal kategori ima etmek ya da yaratmak anlamına gelmediğini ifade etmektedir (İOM, 2019).

Kavramın sahip olduğu geniş anlam yelpazesinden dolayı modern göçmenlik çalışmaları literatürü, farklı türlerdeki çağdaş göçmenlerin çeşitli tipolojileri ile doludur (Tsuda vd.,2015,s.21). Robin Cohen gibi kimi göç tarihçileri yakın tarihteki göç dönemlerini; i)18. ve 19. yüzyıl baskın göç hareketleri olarak kölelerin zorla nakliyesi, ii)Amerika Birleşik devletlerinin sınai güç olarak yükselmesi, iii)İkinci Dünya Savaşı sonrası yaşanan nüfus hareketliliği olarak siralarken (Koser, 2007, s.2-4); Andres Solimano (2010, s.2) göçü globalizasyon merkezli ele almakta ve dünyada yaşanan ekonomik globalizasyon dalgalarını; i) 1870-1914 yenidünya ekonomilerine yönelik başlayan göç akınları ve ii) 1971/73- günümüze serbest sermaye hareketliliği ile yükselen göçler, olarak sıralamak sureti ile göç tarihi okuması yapmaktadır. Göç üzerine bu şekilde yapılan farklı tanım ve tarihsel ayırımları arttırmak mümkündür. Bu farklı tanımların hemen hepsi göçü, farklı bir bağlamı üzerinden doğru bir biçimde anlamlandırmaktadır.

Her ne kadar tüm nüfus hareketlilikleri göç kavramının şemsiyesi altında değerlendirilebilir olsa da görünürlükleri faklıdır. Dünyadaki insanların büyük çoğunluğu sınır ötesi değil kendi ülkeleri içinde çok daha büyük sayılar ile göç etmektedir. Mesela 2009 yılında yaklaşık 740 milyon iç göçmen olduğu tahmin edilirken 2010 yılındaki kayıtlara göre 221.714.243 uluslararası göçmen bulunmaktadır (İOM, 2018b, s. 2,15). Nicelikteki bu farka rağmen göç literatürü genellikle en görünür bağlam olan uluslararası nüfus hareketlerine odaklanmaktadır.

\footnotetext{
${ }^{1}$ IOM göçmeni 'genellikle yaşadığı yerden çeşitli nedenlerin etkisi ile geçici veya kalıcı olarak ulusal veya uluslararası olarak uzaklaşan kimse' olarak tanımlamaktadır.
} 
Elspeth Guild'in (2005, s.103) Batı Avrupa toplumlarındaki göçmenleri gruplaştırırken kullandığı görünür ve görünmez olan göçmenler kavramına benzer şekilde iç göç, benzer dil, kültür, fiziksel özellik vs. sahip insanların kendi içindeki nüfus hareketleri olduğu için, bir anlamda görünmezdir. Dolayısı ile göç ve göçmen güncel anlamını çoğunlukla uluslararası ölçekte bulmaktadır. $\mathrm{Bu}$ bağlamda, göç; kişilerin geçici veya daimi olarak başka bir ülkeye yerleşmek üzere menşe ülkelerinden veya mutat olarak ikamet ettikleri ülkeden ayrılmaları(Perruchoud ve Redpath, 2013, s.88) olarak tanımlanmaktadır. Göçmen kavramı için ise çoğu ülke BM'nin tanımını benimseyerek, bir yıl veya daha fazla bir süre boyunca kendi ülkesi dışında yaşayan kişi (Koser,2007,s.16) tanımını kullanmaktadır.

Literatürde genel olarak uluslararası göçmenlerin kategorize edilmesinin üç ana yolu bulunmaktadır. Birinci ayrım, gönüllü ve zorunlu göçmenler arasındadır. Sık sık yapılan ikinci ayrım, siyasi nedenlerden dolayı hareket edenlerle ekonomik nedenlerden dolayı hareket edenler arasındadır. Bu kategori ise genellikle düşük yetenekli ve çok yetenekli olarak sınıflandırmaktadırlar. Son ana ayrım ise yasal ve yasadışı göçmenler arasındadır (Koser, 2007,s.16,17).

Hangi kategoride olursa olsun uluslararası olarak göç etme kararları, dış güçler (ulusal veya uluslararası düzeyde) ve bireysel tercihler (kişisel veya aile düzeyinde) arasındaki karmaşık bir etkileşimi yansıtmaktadır (Andres, 2010, s.23). $\mathrm{Bu}$ karmaşı etkileşimi var eden bağlamların literatürde teorize edilmeye çalışıldığı görülmektedir. Uluslararası göçe; ekonomik bağlamı üzerinden yaklaşan araştırmacılar itme-çekme teorisi ile hedef ülkedeki çekici unsurlar ve menşe ülkedeki itici unsurlar üzerinden bir yaklaşım geliştirmektedirler. Sosyal ağ teorisi, göç eden insanlar arasında var olan toplumsal bağları önceleyerek, bu bağların kişileri uluslararası göçmen olmak için motive ettiğini vurgulamaktadır. Kurumsal teoriler göçün sadece bireylerle ilgili olmadığı göç sürecinin başlaması sonrasında sürece dâhil olan yasal ve yasal olmayan kurumsallaşmaları ön plana çıkartmaktadır. (Sert, 2016, s. 31,40,41). Göç sistemleri teorisi ise, göç hareketlerinin genellikle veren ve alan ülke arasında sömürgecilik, siyasal etkileşim, ticaret, yatırım veya kültürel bağlara dayanan ve önceden var olan bağlantılar üzerinden ortaya çıktığını ileri sürmektedir (Castles ve Miller, 2008, s.36).

$\mathrm{Bu}$ teoriler 1şında bakıldığında terazinin bir kefesinde hedef ülkeler diğer kefesinde de menşe ülkelerin bulunduğu görülmektedir. Kimi zaman hedef ülkelerin göçmen talep ettiği ve menşe ülkelerin buna karşılık verdiği durumlarla sıklıkla karşılaşılmaktadır. Hedef ülkelerdeki ekonomik olgunluk, yavaş veya durgun nüfus artış1, düşük doğurganlık oranları ve yaşlanan bir nüfusla bir arada bulunmaktadır. Bazı gelişmiş ekonomilerde nüfus daralmaktadır. Bu nedenle göç, teknoloji, sağlık, inşaat, tarımda büyüme ve istihdam işlerini destekleyecek yüksek yetenek gerektiren işlerde girişimci, profesyonel, arzını sağlamaktadır veya yerli vatandaşların giderek daha fazla yapmaktan imtina ettiği işlerde düşük yetenekli çalışanların arzını sağlamaktadır (Andres, 2010, s.2). Buna karşılık menşe ülkelerdeki "çevresel, ekonomik ve siyasi bozulma, geçim kaynaklarını artık koruyamadıklarından, habitatlarını bırakan çevre göçmenlerini, etnopolitik çatışma veya zulümden kaçan siyasi mültecileri ve başka yerlerde daha iyi ekonomik firsatlar ve geçim kaynakları arayan ortak veya işçi göçmenlerini" (Tsuda ve Baker, 2015, s.296) hedef ülkelere yönelmektedirler. Terazinin dengede olduğu durumlarda göç, jeopolitik, ticaret ve kültürel alışveriş ile iç içedir ve devletlerin, işletmelerin ve toplulukların çok fazla yararlanma imkânı sağlamaktadır (İOM, 2018b, s.1).

Fakat kimi zamanlar da menşe ülkedeki ekolojik, ekonomik veya sosyal bozulma o kadar hızlı ve yoğun olmaktadır ki terazinin diğer kefesinde bulunan hedef ülkelerde de ekonomik ve siyasi bozulmalara neden olabilmektedir. Hedef ülkeler ise göç nedeni ile yaşayabilecekleri sosyal veya ekonomik bozulmanın zararlarından korunabilmek için ise giderek daha sıkı göç rejimlerini tercih etmektedirler.

Dolayısı ile menşe ülkesinde ekonomik, siyasi ve çevresel bozulmadan kaçan göçmenler, hedef ülkelerin ihtiyaç ve sakınma durumlarına göre, yönetilmesi gereken sosyoekonomik gelişim veya gerilim üretmektedirler. Hedef ülkelerin kendileri için belirledikleri ihtiyaçlar ve sakıncalar uluslararası göçmenler karşısındaki hukuki tavırlarını da belirlemektedir. Mesela 19. yüzyıl sonlarından 20.yüzyıl ortalarına kadar uluslararası göç, Amerika Birleşik Devletleri, Kanada, Arjantin, Avustralya, Brezilya ve Yeni Zelanda gibi yeni hedef ülkelerdeki ekonomik büyüme için önemli bir motordu. Dünya Savaşı'na kadar uluslararası seyahat nadiren pasaport kullanımına maruz kalıyordu, sınırlar kolayca aşılabilmekteydi. Ayrıca, ülkeler göçmenleri cezp etmek için istekliydiler. Örneğin, 19. yüzyıl ortalarında, Arjantin'in hükümeti Avrupalı göçmenlere ücretsiz gemi taşımacılığı, otomatik Arjantin vatandaşlığı ve toprak mülkiyeti sundu, çünkü ülkenin çiftliklerde ve fabrikalarda çalışmak ve yeni yatırımlar yapmak için insanlara ihtiyacı vard. ABD aynı zamanda iç sınırını genişletmek ve insanların geniş toprak alanlarından istifade etmesi, altının keşfedilmesine yardımcı olmak ve 19. yüzyılda sanayileşmeyi desteklemek için kol ve beyin göçünü teşvik etti. 1820 ve 1880 arasında, siyasi ve ekonomik koşullar ABD'ye 2,8 milyondan fazla İrlandalı göçmen getirdi. Fakat zamanla 1875 'te Kongre, hükümlü ve fahişelerin kabul edilmesini yasaklayan göçmenlik için ilk kısıtlayıcı tüzüğü kabul etti. Etnik kısıtlamalar, Çin göçmenleri (Çin Dışlama Yasası 1943'te yürürlükten kaldırıld1) ve daha sonra 1907'de Japonlar gibi belirli milletlere düştü. 1920 'de Amerika Birleşik Devletleri'nde yaşayan 105 milyon insanın yaklaşık 14 milyonu yabancıydı. 21. yüzyılın başlarında, zengin sanayileşmiş ülkeler, vize yapılarında göçmen kategorileri için beceri düzeylerine, eğitimlerine ve özel uzmanlık ve bilgi birikimlerine göre farklılıklar yaratarak kısıtlayıcı politika ortamlarını artırmayı seçtiler(Andres, 2010, s.1,6,7).Benzer kısıtlayıcı süreçler diğer göç alan Kanada, Avustralya vb. gibi göç alan ülkeler içinde geçerlidir.

Göçmen ve azınlık grupları özellikle19.yüzyıl içinde ulusdevletin doğuşu ve yükselişi ile birlikte, ulusal kimliğin yaratılması, devlete olan aidiyet hissinin pekiştirilmesi için gerekli görülen biz ve onlar ikileminin geliştirilmesi ve devletlerin 'bizim' denilmesi planlanan bir modern ulus devlete dönüştürülmesinde kullanılmıştır (Bekerman ve Geisen, 2011, s.743). Böylelikle kozmopolit ve çok kültürlü imparatorluklar bile modern ulus devletlerin merkezinde yer aldığı, mümkün olduğunca, homojen toplumsal ve siyasal kümelere/devletlere bölünmüştür. $\mathrm{Bu}$ devletler kendi ulus tanımlarına benzer kişileri egemenliklerindeki topraklara gelmeleri yani uluslararası göç etmeleri için 
teşvik ederken, kendi topraklarına azınlık durumunda olan unsurların ise makbul sayıldıkları ulus devletlere gitmelerini yani uluslararası göç etmelerini kolaylaştırmıştır.

Günümüzde göçün hedefinde olan devletler kendi ihtiyaçlarını belirleyerek sınırlarında tam bir seçici geçirgenlik sürecini uygulamaktadırlar. Böylelikle çağdaş göç politikalarının temelini teşkil eden iki yön oluşmaktadır. Birincisi, göç etmek isteyen veya göç eden kişilere nasıl cevap verileceğidir. Bu, göç politikaları, göç yönetimi, sınır kontrolleri, kabul ve dışlanmanın etik sorunlarını içermektedir. Diğer soru, zaten ev sahibi bir ülkede bulunan ve belgelenmemiş kişilere nasıl cevap verileceğidir. $\mathrm{Bu}$ durum (gönüllü) geri dönüş, sınır dışı etme veya düzenlenme ile eşit derecede adaletle ilgili etik konuları içermektedir.Göç ikilemine önerilen ve uygulanan politika çözümleri açıktır. En büyük endişe, göçün nasıl kontrol edileceği, içerileceği veya yönetileceğidir (Düvel, 2006, s.226,231).

Her ne kadar modern ulus devletlerin göçün kontrolüne, göçmenlerin entegrasyonuna ve göç yönetimine imkan sağlayan yasal ve kurumsal düzenlemeleri net ve keskin olsa bile 7.5 milyarı geçen dünya nüfusu, çevresel felaketler, politik çalkantılar ve ekonomik eşitsizlik, ulaşımı ve iletişimi olağan üstü yaygınlaştıran teknolojik ilerlemeler göçün ve göçmenin geleneksel tanımlarının silikleşmesine dolayısı ile göçün kontrolünde, entegrasyonunda ve yönetimde zorluklara neden olmaktadir.

Göçün kontrol edilmesi bağlamındaki zorlukları sıralamak gerekirse; öncelikle ulus devletin sınırlarının (Border) her zaman tarihten beri gelen kültürel yaşam alanlarının sınırları (Boundaries) ile her zaman kesişmemesi aslında aynı coğrafyanın, dilin, kültürün insanlarının günümüzde uluslararası göçmen statüsüne sokmaktadır². Göçmenler için artık menşe ülkeleri, transitler ve varış yerleri arasındaki geleneksel ayrım giderek bulanıklaşmaktadır. Bugün dünyadaki hemen hemen her ülke hedef, transit, menşe rollerini de yerine getirmektedir. Son birkaç yüzyıl boyunca gerçekleşen büyük hareketlerin çoğu kalıcı iken, bugün geçici göç çok daha önemli hale gelmektedir. Fakat buna rağmen bir zamanların geleneksel göç şekli olarak eve (memlekete) dönüş aşamalı olarak bitiyor gibi görünmektedir. Ayrıca günümüzde göçmenlerin arasında kadınların oranı hızla artmaktadır (Koser, 2007, s.6-8). Bunun yanında göç hukukundan kaynaklanan sebeplerle kişilerin statülerinin çok kolaylıkla değişebildiği görülmektedir. Turizm, eğitim, çalışma vb. sebeplerle hedef ülkeye giriş yapan kişilerin sürelerini geçirmeleri halinde yasadışı uluslararası göçmen statüsüne geçebilmektedirler. $\mathrm{Bu}$ durumun tersi olarak da yasa dişı yollarla hedef ülkeye ulaşmayı başaran kişiler mülteci statüsünü kazanabilmektedirler.

Göçmenlerin entegrasyonu bağlamındaki zorluklar ise hedef ülkeler için görünür, görünmez ve yıkıcı göçmen

${ }^{2}$ Sınırlar (Boundaries) farklı çevresel, kültürel, dilbilimsel, ekonomik veya politik alan veya bölgeleri ayırır ve genel olarak bunlar arasında daha esnek bir harekete izin verir. Sınır, (Border) ulus devletler, politikalar ve imparatorluklar arasında bulunanlar gibi siyasi bölgeleri belirleyen belirli bir sinır türüdür (Tsuda vd.2015, s.20). kategorilerinin oluşmasıdır. Mesela tüm Batı Avrupa toplumlarında görünür olan ve görünür olmayan şeklinde tanımlanabilecek iki grup göçmen vardır. Görünürlüğün ev sahibi topluluğun algıları ile ilgisi bulunmaktadır. İngiltere'de çoğu ABD, Kanada ve Avustralya göçmeni görünmezdir. $\mathrm{Bu}$ kişilerin yasal statüleri ne olursa olsun sosyal terimlerle göçmen olarak tanımlanmazlar. Hatta göç kelimesi artık Avrupa Birliğine üye devletlerin vatandaşlarının birinden diğerine hareketi ile ilgili olarak kullanılmamaktadır. Ruslar ve Nijeryalılar ise görünür göçmendirler ve sosyal anlamda da göçmen olarak siniflandirılirlar. Hatta Kanadalilardan ve Avustralyalılardan beklenmeyen şekilde topluma uyum sağlamaları beklenmektedir (Guild, 2005, s.103,105). Diğer yandan bazı göçmen gruplarının ev sahibi toplum üzerinde diğerlerinden daha yıkıcı bir etkisi olduğu inkâr edilemez. Belirli bir göçmen grubun yol açtığı bozulma derecesi, çeşitli ekonomik, sosyal, politik ve etnik etkilerin incelenmesiyle değerlendirilebilirken, göçün yıkıcı sonuçları da bir toplumsal sosyal alg1 meselesidir. Mesela ABD için bazı göçmen grupları her zaman diğerlerinden daha olumlu olarak görülmüştür. 19. yüzyılda Amerika'da Alman göçmenler İrlandalılara tercih edilirdi veya şimdi Meksikalı göçmenler Asya'dan gelen göçmenlerden daha yıkıcı görülmektedir. Amerikan halkı, Meksikalı göçmenleri yıkıcı olarak görmektedir. Çünkü onlara göre Meksikalılar ekonomiyi olumsuz yönde etkileyen ağırlıklı olarak fakir, daha az eğitimli ve vasıfsız göçmen işçiler olarak algılanmaktadır. Buna karşılık, Asya'daki göçmenler bilgi ve becerilerini ekonomiye katkıda bulunan ve Amerika'nın teknolojik ve bilimsel rekabetçiliğini artıran yüksek vasıflı/profesyonel göçmenler olarak görülmektedir(Tsuda, 2015, s.243,253).

Göçün yönetimi bağlamı ise göçün kontrolünü ve entegrasyonu da içine alan ve daha başka birçok ekonomik ve toplumsal dinamiği de denkleme sokmaktadır. $\mathrm{Bu}$ dinamiklerin başlıcası göç ve güvenlik arasındaki ilişkidir. Özellikle 11 Eylül'den sonra uluslararası göç ile terörizm arasında yakın bir bağlantı olduğu algısı oluşmuştur. $\mathrm{Bu}$ algı Madrid ve Londra'da yapılan saldırılarla pekişmiştir. Hedef ülke statüsündeki ülkelerde, ev sahibi toplumlar, özellikle dünyanın aşırılık yanlısı ve şiddetle öne çıkan bazı yerlerinden gelen yabanc1 kültürleri olan göçmen toplulukların varlığından korkmaktadırlar (Koser, 2007, s.11). Bu korku, uluslararası terörizmin medyanın gündeminden hiç düşmemesi sayesinde sürekli diri kalmaktadır. Fakat en önemli nokta ev sahibi toplumların korktukları kişilerin artık televizyon ekranında değil mahallerinde, sokaklarında hiç de azımsanmayacak sayılarda olmalarıdır. Öyle ki dünyanın gelişmiş bölgelerinde, göçmenlerin net girişi, 1990'lı yıllardan bu yana nüfus artışının birincil kaynağı olarak doğal artışın (ölümler üzerindeki doğumların fazlalığı) üzerine çıkmıştır. Uluslararası göçün, 2020'den sonra gelişmiş bölgelerde nüfus artışının ana itici gücü olarak kalacağı tahmin edilmektedir. Buna karşın, göçün gelişmekte olan bölgelerdeki toplam nüfus değişikliği üzerindeki etkisinin önümüzdeki birkaç on yılda nispeten küçük kalması muhtemeldir (UN, 2018, s.22).

$\mathrm{Bu}$ durum göçü yönetmesi gereken politik sistemi ve toplumsal düzeni doğrudan etkilemektedir. Birçok göçmenin Avrupa'da karşılaştığı 1rkçılık ve Avrupa siyasetindeki aşırı sağın yükselişi, var olan birçok toplumun 
hissettiği bu daha derin güvensizlik ve marjinalleşmeye dayanmaktadir (Braloand ve Morrison, 2005, s.116). Üstelik bu birçok ülkenin sorunudur. Göçmenlerin yerel nüfus üzerindeki ekonomik, sosyal ve kültürel etkileri ile göçün kamu politika yapıcıları için yarattığı temel zorluklar açısından ülkeler arasında bazı benzerlikler açıkça görülmektedir (World Migration Report, 2018, s.92).

Göçün hedef ülkede yaratabileceği bozulmanın derecesi iki temel faktöre bağlıdır. Birinci faktör göç ve göçmenler bakımından; göç akışının hızı, boyutu, süresi, sıklı̆̆ı ve göçmen tipidir. İkinci faktör ise ev sahibi toplumun dayanıklılığıdır. (Baker ve Tsuda, 2015, s.304,307).

Güncel sayılara baktığımızda "2000 yılından bu yana, uluslararası göçmen sayısı küresel olarak yüzde 49 artarak 2017 yılında 258 milyona ulaşmıştır. Uluslararası göçmenlerin toplam nüfus içindeki payı da artmıştır. Uluslararası göçmenler, 2000 yılında \% 2,8'i oluştururken, şimdi, küresel nüfusun \% 3,4'ünü oluşturmaktadır (UN, 2018, s.22). \%3.4'lık değer sayılara vurulduğunda ise tablo daha çarpıcı bir biçimde görünmektedir. Siyasal sebepler nedeni yani zulüm, çatışma, genelleştirilmiş şiddet veya insan hakları ihlalleri nedeniyle 2017 yılının sonuna kadar dünya genelinde 68,5 milyon kişi zorla yerinden edilmiştir. Çevresel sebepler 135 ülkedeki 18,8 milyon kişi, 2017'de kendi ülkelerinde ani başlayan felaketler nedeniyle yeni yerlerinden edilmiştir. Bu sayılara bir de 150,3 milyon göçmen işçi (2015 y1lı verisi), 4,8 milyon uluslararası öğrenci (2016 yılı verisi), 25,4 milyon kayıtlı göçmen (2017 y1lı verisi), tahmini 50 milyon düzensiz göçmen (2009 y1lı verisi) vb. gibi eklendiğinde yaklaşı 258 milyon kişinin 2017 yılında küresel olarak doğdukları ülke dişındaki bir ülkede ikamet ettikleri görülmektedir (İOM, 2018a,s.18,28).

Günümüzde çatışma, genelleştirilmiş şiddet ve diğer faktörlerin neden olduğu küresel yer değiştirme rekor seviyededir (İOM, 2018b, s.41) . Gelişen uluslararası göçün bu denli yoğun, hızlı ve sürekli olması, ABD, Kanada ve Avustralya gibi ülkelerin bile dayanıklılığını zorlamaktadır. Ev sahibi toplumlar tarafinda görünür hatta yıkıcı olarak algılanan göçmen kitlesi, yaşanan politik ve ekonomik istikrarsızlıklar nedeni ile her geçen gün büyümektedir. Göçmen bir hareketin en yaygın sonucu, baştaki niteliği ne olursa olsun, göçmenlerin önemli bir kısmının yerleşmesi ve yeni ülkede etnik cemaat veya azınlıkların oluşumudur. Ev sahibi toplum içinde giderek artan bir hızla 'etnik azınlık' oluşturan bu kitlenin, cemaatlere benzer biçimde belli semtlerde toplanmak sureti ile kendi dillerini ve kültürlerini koruma eğiliminde oldukları görülmektedir. Buna ilaveten, zaten sosyo ekonomik olarak dezavantajlı olan bu insanlar vatandaşlığa kabul edilmeme, sosyal ve siyasal haklardan mahrumiyet, etnik veya ırkçı ayrımcılık, 1rkçı şiddet ve nefret gibi nedenlerden toplum genelinden kısmen dişlanmaktadırlar (Castles ve Miller,2008,s.64,346). Teknolojinin gelişmesiyle birlikte, göçmenler televizyon ve internet aracılığıyla geldikleri ülkelerde yaşanan günlük politik, ekonomik ve sosyo-kültürel gelişmelerden de günü gününe haberdar olmaktadır. Bu şekilde anavatanları ile bağları zamanla güçlenmekte ve coğrafi olarak ayrı ülkelerde yaşasalar bile zihinlerinde aynı anda iki ülkede yaşayabilmektedirler (Özkul, 2016,s.487). Bu duruma bir de ev sahibi toplumlarda göçmenler aleyhine gelişen korku, ön yarg1 hatta karşılıklı şiddet eklendiğinde göçün yönetiminin hayatiyeti anlaşılacaktır.
Göç edenlerin ev sahibi toplumlara dâhil edilmelerindeki başarısızlık ise kendini büyük eşitsizlik ve çatışmalarla gösteren bölünmüş toplumlara yol açabilmektedir (Castles ve Miller,2008,s.55). Bu bağlamda ev sahibi toplum ama özellikle göçmenler üzerinde toplumsal bölünmeye ilişkin 'toplumsal nabzın' anlaşılmasına imkân verecek akademik çalışmaların önemi büyüktür.

\section{Türkiye'de Göçmen ve Yabancı Olmak}

Osmanlı imparatorluğu göçlerle başlamış ve göçlerle dağılmıştır. 19. yüzyılın ikinci yarısında yine göçler sayesinde büyük değişimlere uğrayarak, 'Türk' karakteri çok olan bir toplumun ve devletin ortaya çıkarmıştır (Karpat, 2015, s.xxvi). Osmanlı devleti iskan politikalarını/kurumunu, idare ettiği 'mülk'ü, ekonomik, sosyal, kültürel (dini), güvenlik vb. gerekçelerle etkin bir biçimde yönetmek maksadı ile kullanmıştır (İçduygu vd., 2014, s.82-99).

Türkiye Cumhuriyeti de kuruluşundan itibaren göç alan bir konumundadır (Ciğerci,2016, s.108).İskân/göç politikaları bir kurum olarak sadece Osmanlı döneminde değil, Cumhuriyetin kuruluş ve sonrasındaki dönemlerinde de etkisini hissettirmiştir (İçduygu vd., 2014, s.169). Cumhuriyet'in ilk yıllarından itibaren Türkiye'ye yönelen uluslararası göç hareketleri, ulus devletin kuruluşunda son derece önemli rol oynamıştır.

Cumhuriyet'in kuruluş yıllarından başlayarak, ilk kırk yıl içinde Türkiye'ye yönelen bu göç dalgalarını, genelde Osmanlı İmparatorluğu'nun toprakları içinde kurulan çevre ülkelerden gelen etnik Türk ve Müslüman göçmenler oluşturmuştur (Balkır ve Kaiser, 2015, s.223). Tarihi süreç itibari ile iskân politikalarının kullanım nedenleri ve biçimleri değişiklik göstermekle birlikte Cumhuriyet kendi göç ve iskân kurumunun temel kriterlerini 2510 kanun numaralı 1934 tarihli İskân Kanununda açıkça ifade etmiştir. 1934 tarihli İskân Kanunun 3. maddesinde; "Türkiye'ye yerleşmek maksadı ile dışarıdan, münferiden veya müçtemian, gelmek isteyen Türk soyundan meskûn veya göçebe fertler ve aşiretler ve Türk kültürüne bağlı meskûn kimseler, iş bu kanunun hükümlerine göre Dâhiliye Vekilliğinin emrile kabul olunurlar. Bunlara (muhacir) denir." denilmektedir. Yine aynı kanunun 4. maddesinde; "Türk kültürüne bağlı olmıyanlar, anarşistler, casuslar, göçebe çingeneler, memleket dışına çıkarılmış olanlar, Türkiye'ye muhacir olarak alınmazlar" denilmektedir. Bu bağlamda 2006 yılında yeniden düzenlenen 5543 nolu İskân Kanunu da 1934 tarihli kanunun ruhuna sadık kalmıştır. 2006 tarihli İskân Kanunun 3. maddesinde; “Göçmen; Türk soyundan ve Türk kültürüne bağlı olup, yerleşmek amacıyla tek başına veya toplu halde Türkiye'ye gelip bu Kanun gereğince kabul olunandır" denilmektedir.

Dolayısı ile anlaşılmaktadır ki Türkiye'de kanuni anlamda göçmen 'Türk olmak veya Türk kültürüne bağlı olmak' bakımından 'bizden/görünmez' olarak tanımlanırken, diğerleri 'yabanc1/görünür' olarak dişarıda bırakılmaktadır. Elbette ki 'bizden' olmayan biri, hukuki olarak vatandaşlık alsa bile,sosyal anlamda, az veya çok, hala 'yabancı' olarak değerlendirilmektedir. Önceki başlıkta ifade edildiği gibi, $\mathrm{AB}$ ülkelerinin Avustralya ve Kanadalı göçmenlerden çok daha fazla Ruslardan, Nijeryalılardan topluma uyum sağlamaları beklentisine benzer şekilde Türkiye'de de 'göçmenlerden' çok daha fazla 'yabancılardan' topluma 
uyum sağlamaları beklenmektedir. Çünkü daha görünür olanın davranışları, daha fazla 'göze batmaktadır'.

Literatürde Türkiye'deki göç süreci genellikle kronolojik olarak değerlendirilmektedir. Fakat Türkiye'deki göçün, makalenin tartışmaya çalıştığı ve göçün geldiği nokta itibari ile genel kronolojiyi de kapsayacak bir anlatımla yani görünür (yabancılar/öteki), görünmez (bizden/kurucular) ve yıkıcı göçmenler üzerinden ele alınmasının daha uygun olacağı değerlendirilmektedir.

Görünmez göçmenler Türkiye'nin kuruluşu için ihtiyaç duyulan nüfusun Osmanlı İmparatorluğunun Türkiye dışında kalan topraklarından (Yunanistan, Bulgaristan, Romanya, Yugoslavya vb.) gelen Türk soylu veya Türk kültürüne bağlı kişi ve gruplardır. Görünmez göçmenler bir anlamda kurucu göçmenlerdir.

1923-1960 yılları arası dönemde göç ulus devleti oluşturmak amacı ile kullanılmıştır (Aktaş, 2015, s.33). Geleneksel olarak Türkiye Cumhuriyeti bu kişilerin ülkeye göçünü teşvik etmiştir (Kirişçi ve Karaca, 2015, s.299). Ayrıca, bu yerleşme sırasında, gelenlerin geldikleri yerlerdeki statülerinin devam etmesine ve oradaki toplumsal hiyerarşi içindeki konumlarının korunmasına özen gösterildiği anlaşılmaktadır (İçduygu vd., 2014, s.144). 1989'da Bulgaristan'dan Türkiye'ye sınır dıșı edilen Türk, Pomak ve Romanlar ile yine aynı yılsonunda Özbekistan'dan kaçan Ahıska Türkleri ayrıca Çerkezler 20. yüzyılın son iskânlı göçleri olmuştur (Özgür, 2016, s.209). Türkiye Cumhuriyetinin 1923-2010 arasında, çok büyük bir bölümü 'soydaş' olarak nitelenen göçmenleri ülkeye kabul etme sürecince toplamda 2 milyon civarında göçmen alındığı bilinmektedir (Kaya ve Erdoğan, 2015, s.12). Kurucu unsur olarak kabul edilen görünmez göçmenlerin ülkeye girişleri kolaylaştırılmakta, geldikleri iklime uygun alanlarda iskân edilmeleri sağlanmakta ve hizla ekonomik, sosyal, kültürel, siyasi vb. gibi hakları kendilerine verilmektedir. Görünmez göçmenler zaten benzer kültür havzasından olmaları bakımından göçtükleri bölgelerdeki toplumsal sosyalleşmenin kodlarını bilmektedirler.

Ülke dışından gelen bireysel ve kitlesel görünmez göçlerin yanında özellikle 1950'lerden sonra başlayan köyden kente yönelen 'iç göç'ü ve Türkiye'den gelişmiş ülkelere giden 'iş/emek göçü'nü yine görünmez göçmenler kategorisinde değerlendirmek mümkündür.

Görünür göçmenler: 1980 sonrasında Türkiye'nin göçün hedef ve transit ülkesi durumuna gelmesi ile hissedilmeye başlanılmıştır. Türkiye'nin görünür göçmenleri hukuki veya toplumsal anlamda yabancı olarak değerlendirilen göçmenleridir.

1980'ler de modern Türkiye tarihinde ilk kez kökenleri itibariyle Türk ve Müslüman olmayanların Türkiye'ye göçüne tanık olunmuştur. Kısacası ilk kez 'yabancıların' Türkiye'ye göçünden söz edilebilecek bir döneme girilmiştir. Türkiye'ye 'göçmen' değil ama daha çok 'yabanci' olarak nitelendirilen kişilerin kitle halindeki gelişleri, Türkiye'nin uluslararası göç rejimindeki konumunu değiştirmiş, önceleri sadece 'göç veren' bir ülke olarak bilinen tekli konumuna artık 'göç alan' ve 'geçiş' ülkesi olma durumlarını da katarak üçlü bir konum meydana getirmiştir (İçduygu vd., 2014, s.58,222). Bu nedenle, yakın zamana kadar Türkiye'de uluslararası göç sonucu oluşan 'yabanc1' bir nüfustan bahsetmek mümkün değildir (Balkır ve Kaiser, 2015, s.223).

$\mathrm{Bu}$ bağlamda Türkiye'deki görünür göçmenleri yasal ve yasa dışı (düzensiz göçmen) yolları kullanmak sureti ile eğitim ve iş için ikamet izni almak, başka ülkeye geçmek, sığınmak/iltica, uluslararası koruma, şartlı iltica, ikincil koruma, geçici koruma talep etmek gibi nedenler ile Türkiye'de bulunanlar oluşturmaktadır. $\mathrm{Bu}$ kategoriler başlangıçta çok keskin hukuki çizgiler gibi görünse bile zaman içinde birleşik kaplar (eğitim için gelen iş için kalabilmekte, sığınmacı olan başka bir ülkeye geçebilmekte vb.) gibi bir işleyişleri bulunmaktadır.

Türkiye'ye gelen göçmenlerin bir başka özelliği de göç edenlerin uyruklarındaki farklılıktır. 1994-2004 yılları arasında Türkiye'ye 163 farklı uyruktan göçmen gelmiştir (İçduygu, 2004, s.9,72).

Fakat Türkiye'nin karşı karşıya kaldığı dışarıdan kaynaklı en ciddi kitlesel göç hareketi ise 2011'de Suriye'den başlamıştır. Suriye'den 4 yılda gelenlerin sayısı 88 yılda Türkiye'ye gelenlerin sayısını aşmıştır (Kaya ve Erdoğan, 2015, s.11-12). Bunda, Türk Hükümetinin zulüm ve savaştan kaçan bu misafirler için sınırların açık olduğunu ve öyle kalacağını, gelenlerin Türkiye'deki temel ihtiyaçlarının karşılanacağını ve kimsenin zorla geri gönderilmeyeceği yönündeki politikası ve bunu destekleyen uluslararası koruma ilkeleriyle tam uyumlu olan 'açık kapı politikası' sürecin başından beri zaman zaman ciddi somut güvenlik kaygıları ile bazı aksaklıklar yaşansa da prensip olarak sürdürülmesinin (Erdoğan, 2016, s.70) katkıs1 büyüktür.

Türkiye'ye yönelik olan yabancı göçüne kabaca bakıldığında;

OECD (2018,s.282) verilerine göre; Türkiye'de yükseköğretim kurumlarındaki yabancı öğrenci sayıları giderek artmaktadır. 2016/17 y1lında 108.000 yükseköğretim öğrencisi bulunmaktaydı. $\mathrm{Bu}$ rakam bir önceki yıla göre \%23'lük bir artış1 işaret ederken 2013/14 eğitim öğretim yılındaki rakamın yaklaşık iki katıdır. Yükseköğretim için gelen yabancı öğrencilerin menşe ülkeleri ise Suriye, Azerbaycan, Türkmenistan, Afganistan, Irak gibi ülkelerdir.

Göç İdaresi Genel Müdürlüğünün açık kaynak olarak paylaştığı, ikamet izni, uluslararası koruma başvurusu, düzensiz göçmenler, geçici koruma altındaki Suriyelilere ilişkin istatistiklerine göre;

Türkiye'de ikamet izni ile bulunan yabanciların 2015 yılındaki sayıları 178.964 iken 03.10.2109 tarihi itibari ile 1.059.916 sayısına ulaşmış yaklaşık altı kat artmıştır. 2018 yılında İkamet izni alan kişilerin menşe ülkelerine baktığımızda; Irak (104.444), Suriye (99.643), Türkmenistan (67.522), Azerbaycan (65.027), İran (44.313), Afganistan (39.283), Rusya (36.507), Özbekistan (34.727), Misir (25.784), Kirgizistan (25.645) olarak sıralandıkları görülmektedir. 2018 yılında ikamet izni alanların 563.093'ü kısa dönem, 75.122'si aile ikamet izni, 79.225'i öğrenci ikamet izni, 85.840'1 çalışma izni ve 53.190'1 diğer nedenler ile ikamet iznine sahip olmuşlardır.

Uluslararası koruma başvurusu, 2010 y1lında 8.932 iken 2018 yılında 114.537 sayısına ulaşmış ve yaklaşık 13 kat artmıştır. 2018 yılı menşe ülke dağılımlarına bakıldığında 
ise; Irak (68.117), Afganistan (37.854), İran (5.036), Somali (1.723), Pakistan (227), Filistin (183), Türkmenistan (168), Yemen (138), Özbekistan (96) olarak siralandıkları görülmektedir.

Düzensiz göçmenlere ilişkin istatistiklere bakıldığında 2005 y1lında yakalanan düzensiz göçmenler 57.428 kişi iken bu rakam 02.10. 2019 tarihi itibari ile 316.824 sayısına ulaşmış yaklaşı1k 5.5 kat artmıştır. Düzensiz göç sadece yasadışı yollarla ülkeye girenleri değil yasal olarak giriş yaptıktan sonra eksik dokümandan dolayı yasadışı duruma düşenleri de kapsamaktadır. "Polisin Türkiye'ye gelen ve yasal göç boyutlarını zorlayan bu göçmenlerin ancak yarısını yakalayabildiği tahmin edilmektedir" (İçduygu, 2004, s.89). Dolayısı ile henüz Suriye'den Türkiye'ye kapı açılmadan önce belirtilen bu tahmin bağlamında günümüzde yakalanan düzensiz göçmenlerin var olanın en az yarısı kadar olduğunu varsaymak oldukça iyimser bir tahmin olmasına karşın düzensiz göçmenlerin sayısını bir milyona yaklaştırması bakımından çarpıcıdır.

Geçici Koruma Altındaki Suriyeliler 2011 yılın başında 0 iken 03.10.2019 tarihi itibari ile 3.671.553sayısına ulaşmıştır. 03.10. 2019 tarihi itibari Suriyelilerin 63.294'u Adana, Kilis, Kahramanmaraş, Hatay (Hatay'da 3 barınma merkezi bulunmaktadır) ve Osmaniye'de bulunan toplam 7 geçici barınma merkezlerinde kalırken, 3.608.349'u Türkiye'nin tüm vilayetlerine dağılmış durumdadır. Suriyelilerin yoğunlukla bulundukları ilk 10 il; İstanbul (549.219), Gaziantep (451.183), Hatay (439.869), Şanlıurfa (428.299), Adana (239.033), Mersin (204.255), Bursa (177.087), İzmir (146.891), Kilis (116.289), Konya (109.304) olarak sıralanmaktadır.Geçici koruma altında olan Suriyelilerin 2014-2019 yılları arasında sadece 15.692'si üçüncü ülkelere yeniden yerleştirmiştir.

Yıkıcı göçmenler: Bir önceki başlıkta ifade edildiği gibi i)oluşması göçün hız1, yoğunluğu, göç edenlerin profili, göç edenlerin etkin cemaat veya azınlık olma durumları, göç edenlerin ekonomik, sosyal ve kültürel bozulmanın sebebi olması veya algılanması, ev sahibi toplumun dayanıklılığı ve hedef ülkenin göçü yönetmekteki becerisi birçok farklı değişkenin birbiri ile etkileşimine bağlıdır.Ve ii) Yıkıcı göçmen kategorisi gerçeğe bakan yanından çok bir alg1 durumunu ifade etmektedir. Türkiye özelinde bu değişkenlere bakıldığında yıkıcı göçmen kategorisinin oluşup oluşmadığı bölümün sonunda netleşecektir.

Göçün hızı ve yoğunluğu: Türkiye 1980'lerden sonra Türk ve Müslüman olmayanların da Türkiye'ye göçüne tanık olsa da 2011 yılına kadar gelen yabancı göçü hem nüfusa oranla kabul edilebilir hem de kolluk marifeti ile mücadele edilebilir bir durumdaydı. Fakat 2011 yılından sonra 201819 yıllara gelindiğinde ve 2000'li yılların başındaki rakamlar ile kıyaslandığında eğitim için gelenlerin 2'ye, ikamet izni alanların 6'ya, uluslararası koruma başvurularının 13 'e, düzensiz göçün kayıt altına alınabilenin bile yaklaşık 6'ya katlandığı ve 2011 yılından beri geçici koruma altına alınan Suriyelilerin ise yaklaşık 4 milyona ulaştığı görülmektedir.

Son on yılda gelen yasal ve yasa dişı göçün, 86 yılda gelenden çok daha fazladır. Ülkenin doğusundan ve güneyinden çok yoğun ve hızlı bir yasa dışı göç girişimi devam etmektedir. Güneyde Suriye'den yeni göç dalgalarının gelme ihtimalinin yanı sıra Türkiye'nin doğusundaki ülkelerde bekleyen milyonlarca mültecinin Türkiye'ye akma ihtimali söz konusudur (Arınç,2018,s.1467).

Dolayısı ile son on yılda Türkiye'de çok hızlı ve yoğun bir göç yaşandığı anlaşılmaktadır. 2011 yılı öncesinde kolluk marifeti ile mücadele ile göçü yönetmek mümkünken sonrasında Afet ve Acil Durum Yönetim Başkanlığı, Göç İdaresi Genel Müdürlüğü, Kolluk Birimleri, Belediyeler, Valilikler, Sivil Toplum Kuruluşları vb. gibi devlet ve sivil toplum kuruluşlarının ortak çabası bile göçü yönetmekte zorlanmaktadır.

Göç edenlerin profiline bakıldığında; gelen görünür göçmenlerin, eğitim için yasal yollardan gelenler bir tarafa bırakıldığında, ikamet ve düzensiz göçmen istatistiklerinden anlaşılacağı üzere sosyo ekonomik düzeyi düşük ve sorunlu coğrafyalardan gelen düşük yetenekli kişilerden oluştuğu görülmektedir.

Öte yandan toplumda Suriyelilerin çok fazla suç işlediklerine yönelik büyük bir algı bulunmaktadır. Bu algı tam anlamı ile gerçeği yansıtmasa bile esas mesele bu insanların suç işlemeye yönelik taşıdıkları potansiyeldir. Çünkü Suriyeliler Türkiye'de topyekûn suç işleyen bir topluluk olmamakla birlikte, giderek daha fazla suça iştirak ettikleri de bir gerçektir (Karasu,2017,s.64).

"Suriyelilerin ülkemizdeki sayısal varlıkları, çocuk nüfus oranın fazlalığı, eğitim düzeyinin düşüklüğü ve düşük sosyo-ekonomik düzeye sahip olmaları, suç eğilimi açısından önemli risk unsurlarını oluşturmaktadır (Kızmaz, 2018, s.409)".

Etnik cemaat veya etnik azınlık olma durumları: Yukarıda da ifade edildiği üzere Türkiye coğrafi konumundan dolayı onlarca ülkeden yasal ve yasadışı göç almaktadır. Her nevi düzensiz göçmenlerin ve ikamet izinli yasal göçmenlerin sosyal ağlar üzerinden birbirleri ile etnik veya kültürel cemaat olarak iletişim kurmakta ve dayanışmaktadırlar. Ülkenin doğusundan gelen göçmenler genellikle ailesi olmayan, genç ve üstü yaşlardan müteşekkil bireysel göçmen gruplarıdır. Fakat Suriye'den kaynaklı göçlerde ise aileleri ile birlikte gelen ve çocuk, genç ağırlıklı göçmen gruplarıdır. Dolayısı ile Suriyeliler dışında var olan göçmenlerin etnik azınlık olabilecek bir yoğunluğu yoktur.

Göç İdaresi Genel Müdürlüğünün açık kaynak olarak paylaştığı Kayıtlı Suriyelilerin bulundukları illerin nüfuslarına oranlarına ilişkin istatistiklere bakıldığında Suriyelilerin; 44 ilde \%0-1 aralığında, 15 ilde \%1-2 aralığında, 3 ilde \%2-3 aralığında, 6 ilde \%3-4 aralığında, Adıyaman ve Konya'da \%4-5 aralığında, Bursa ve Kayseri'de \%5-6 aralığında, Kahramanmaraş'da \%8.11, Osmaniye'de \%9.57, Adana ve Mardin'de \%10-11 aralığında, Mersin'de \%11.26,Şanlıurfa'da \%21.04, Gaziantep'de \%22.24, Hatay'da \%27.32, Kilis'de ise \%81.58 olduğu görünmektedir. Bu rakamlar Suriyelilerin Türkiye'de etnik bir cemaat değil etnik bir azınlık, hatta Hatay ilinde olduğu gibi çoğunluk, durumuna geldiğini açıkça göstermektedir.

03.10.2019 tarihi itibari ile geçici koruma altında bulunan Suriyelilerin 1.717 .229 'u 18 ve atı yaş grubundadır. Yani Türkiye'de bulunan Suriyelilerin $\% 46,77$ 'si henüz çocuk statüsündedir.30 yaş altındaki geçici koruma altındakiler 
olarak hesaplandığında ise sayı 2.624.024 yani Türkiye'de bulunan Suriyelilerin \%71,46'sını gençler oluşturmaktadır. Ayrıca cinsiyet dağılımlarına bakıldığında ise 1.989 .887 erkek ve 1.681.666 kadın olarak dengeli bir dağılım bulunmaktadır.Dolayısı ile Türkiye'de etnik azınlık olabilecek sayıdaki Suriyelilerin genç, dinamik ve kendi etnik kültürlerini devam ettirmeleri oldukça olası bir profillerinin olduğu açıkça görülmektedir. Zaten "2016 itibari ile İstanbul'da Suriyelilerin kurdukları çeşitli amaçları taşıyan dernek sayısı 132'ye ulaşmıştır (Esen, 2016, s.34)".

Türkiye'deki Suriyeliler konusu her geçen gün daha belirgin bir biçimde kalıcılığa doğru evirilmektedir. Suriyelilerin hem Türkiye'de kalış süreleri artmakta ve hem bütün kitlesel göçerde yaşanıldığı gibi, kalış süresi arttıkça, kalıcılık da güçlenmekte, hem de Suriye'deki iç savaş, dönüş arzusunda olsa da Suriyelilerin dönme imkânlarını ortadan kaldırmaktadır. Kitlesel göçlerin fitratında kalıcılık olduğu bilinen bir gerçektir (Erdoğan, 2015, s.320).

Castles ve Miller'in (2008, s.20,21,44,344,417) ifade ettikleri gibi göç sürecinin ileriki aşamalarında göçmenler kalıcı olarak yerleşip farklı gruplar oluşturduklarında göçün toplum üzerindeki uzun dönemli etkileri ortaya çıkmaktadır. Bir uçta, yerleşime açmak, vatandaşlığg ve kültürel farklılığı aşamalı olarak kabul etmek, çok kültürlü toplumun bir parçası olarak görülen, etnik cemaatlerin oluşmasında imkân tanıyabilir. Diğer uçta ise, yerleşme realitesini yadsımak, yerleşmiş olanların hak ve vatandaşlık taleplerini geri çevirmek ve kültürel farklılığg reddetmek, varlıkları çoğunlukla bölücü ve sakıncalı olarak değerlendirilen, etkin azınlıkların oluşmasına yol açabilir. Sonuçlar, göç alan ülke ve toplumun tutumlarına bağlı olarak, çok farklı olabilir. Göç ve etnik farklılık bu tür bir ulus düşüncesini tehdit etmektedir. Çünkü etnik kökenleri ortak olmayan bir halk yaratmaktadır. Klasik göç ülkeleri, göçmenlerin entegrasyonunu kendi ulus inşa mitinin bir parçası haline getirerek bu durumla kolaylıkla baş edebilmektedirler. Ne var ki, ortak kültürü kendi ulus inşa süreçlerinin merkezine yerleştirenler için bu çelişkiyi çözmek çok daha zordur. Kültürel olarak farklı yerleşimci gruplar neredeyse daima dillerini ve anavatanların kültürlerinin bazı unsurlarını en az birkaç kuşak boyunca korurlar. Göç eden insanların kültürel farklılığı ulus devleti bir ikilemle karşı karşıya bırakır. Yeni gelenlerin vatandaş olarak birleşmesi kültürel homojenlik mitine zarar verebilir. Bazı örneklerde, göçmenler marjinalleşmiş etnik azınlığa dönme eğilimi taşırlar. Göç yarın bitecek olsa bile toplumları kuşaklar boyu etkileyecektir. Göç edenlerin hedef ülkeye eklemlenmelerindeki başarısızlık bölünmüş bir topluma yol açabilmektedir.

Göç edenlerin ekonomik, sosyal ve kültürel bozulmanın sebebi olması veya algılanması: Disiplinler arası göç ve göç politikaları sempozyumunda (2015, s.605) Türkiye'de işsizlik oranlarının yüzde 10 civarında olduğunu göz önünde bulundurulursa, uzun vadede işsizliğin doğuracağ sorunlara bir de Suriyeli işsizlerin katılması bu sorunu daha da karmaşık bir hale getirecektir denilmektedir. Şanlıurfa'da kamp dışında ikamet eden Suriyelilere ilişkin yapılan bir alan araştırması da (Concern World Wide, 2013) Suriyelilerin ortalama 11 kişilik hane halkına, genellikle konut olarak yeterince elverişli olmayan yapılarda ya da tamamlanmamış yarı inşa halindeki barınaklarda, kalabalık ve dar alanlarda yaşamalarına ve kayıt dışı çalışmalarına karşın ana sıkıntısının ekonomik geçimlerini sağlayamamaları olduğunu ifade etmektedir.

Mersin ilinde yapılan bir diğer çalışmada (Karaca ve Doğan, 2014,s.38-41) ise; Mersin'de yaklaşık 1500- 2000 arası Suriyeli girişimcinin işlettiği işletme olduğu tahmin edilmektedir. Bunların bir kısmı şirket, bir kısmı şahıs işletmesi biçimindedir. $\mathrm{Bu}$ işletmelerin vergi kaydı yapılmaktadır ve sonrası da belirsiz durumdadır. Meslek odalarına kayıt yaptırabilmek için ya Türkiye Cumhuriyeti vatandaşı olunmasını ya da çalışma bakanlığından çalışma izni alınmasını gerektirmektedir. Çalışma bakanlığından alınan izinlerin genellikle bir yıldan daha kısa bir süreli olması; Meslek odalarının kayıt yapamamasına yol açmaktadır. İşletme açılacağı zaman, Suriyeli işletmecilerden istenen belgeler ile yerli girişimcilerden istenen belgeler aynı değildir. Haksız rekabet yaratabilecek uygulamalardan kaçınılması gerekmektedir, denilmektedir ve işsizlik oranlarının yüksekliğinden kaynaklı etnik çatışmaya açık çalışma ortamından bahsedilmektedir.

ORSAM'in raporunda (2015) ise: ekonomik anlamda yerel halk iş firsatlarının ellerinden alındığına inanmaktadır. Ancak iş dünyası açısından bakıldığında bu iddianın karşılığının olmadığı görülmektedir. Normal şartlarda işini kaybedecek kişiler de Suriyeliler nedeni ile işsiz kaldığını düşünmektedir. Suriyeliler küçük işletmeler (fırın, ayakkabı üretimi, vb.) yoluyla üretim ve ticarete katkı sağlamaktadır. Ancak bu işletmelerin tamamına yakınının kaçak olması, vergi vb. yasal yükümlülükleri yerine getirmemeleri dolayısıyla haksız rekabete neden olmaktadırlar. Kaçak Suriyeli çalıştıran ve çalıştırmayan firmalar arasında haksız rekabet ortaya çıkmaktadır.

'Yabancıların' ekonomik yaşam içindeki bu durumuna ek olarak devletin sosyal yardım, sağlık, barınma vb. gibi ihtiyaçları için Suriyelilere harcadığı astronomik paralar beraberinde yüksek bir ekonomik maliyet/bozulma getirmektedir.

Dil, kültür ve yaşam tarzı farklıkları toplumsal uyumu güçleştirmektedir. Etnik ve mezhepsel kutuplaşmayı tetikleyebilecek zemin oluşmaktadır. Suriyelilerin yaşam koşullarının zorluğu ve eğitim imkânından faydalanmıyor olması uzun vadede suç oranlarındaki artış da dâhil bazı sosyal sorunlara uygun zemin hazırlamaktadır. Yerel halk arasında Suriyelilerin asayişi bozduğu yönünde bir söylem oluşmuş durumdadır. Ancak bunun karşılığının olmadığı görülmektedir. Suriyelilerin kenar mahallelerde bir arada yaşamlarını sürdürmesi uyum sürecini zorlaştırmaktadır ve uzun vadede güvenlik sorunlarının doğmasına neden olabilecek bir zemin hazırlamaktadır. En ciddi güvenlik riski yerel halk arasında var olan tepkinin bir provokasyon neticesinde şiddet içeren kitlesel tepkiye dönüşmesi ihtimali olduğu vurgulanmaktadır (ORSAM, 2015).

2012 yllından bu yana Türkiye'deki Suriyelilerin eğitimine yönelik pek çok çalışma yapılsa da 311.256 Suriyeli çocuk Geçici Eğitim Merkezleri (GEM) ve devlet okullarında eğitim görmekte iken, 523.583'ü ise halen okullaşamamıştır. Suriyeli çocukların eğitimi ve uyum süreçlerinde karşılaşılan en önemli sorun alanı dil öğrenimidir. Nitekim gerek devlet okulları gerek GEM'lerde Suriyeli çocuklara verilen Türkçe dersleri eğitici, materyal ve metodoloji eksikliğinden dolayı nitelikli düzeyde değildir. Öğrencilerin GEM'lere devam durumu 
devlet okullarına kıyasla daha iyi görünmektedir. Bunun nedenleri arasında devlet okullarında dil engeli olması, çocuğun kendi yaş grubu ve kademesinde okuyamaması, Türk vatandaşı akranları tarafından dışlanma, öğretmen ve idareciler ile iletişimsizlik gibi sorunlar gösterilmiştir (SETA, 2016).

Suriyeli sığınmacı sayısının \%8.11 gibi bir rakam olduğu Kahramanmaraş'ta yapılan bir alan çalışmasında katılımcıların; \%80'i resmi rakamları inandırıcı bulmadıklarını gerçekte daha fazla yabancının olduğunu; $\% 50$ 'si asla Suriyelilerle komşuluk yapmak istemediğini, \%28.4'ü kısa sureli komşuluk yapabileceğini; \%64.1'i ailesinin ve kendisinin Suriyelilerle ilişki kurmadığını; \%69.5'i Suriyelilerin iş yeri açmasını olumsuz olarak değerlendirdiklerini; \%42.7'si Suriyelilerden güvenlik riski hissettiklerini; \%80'i Suriye'deki iç karışıkların hitamında Suriyelilerin eve dönmesini istediklerini; ifade etmişlerdir (Aydın ve Durgun, 2018).

Suriyelilerin, kendi kültürel 'kültürel gettoları' içinde ve eğitim, öğretim sistemine etkin bir biçimde dâhil olamadan ekonomik ve sosyal alanda var olma imkânına sahip oldukları anlaşılmaktadır. $\mathrm{Bu}$ durum kültürel ve sosyal entegrasyonu zorlamaktadır. Suriyelilerin bir yanda geçici olarak değerlendirilmesi bir yandan da y1llardır 'misafirliğin' bitmemesi ve geleceğin belirsizliği zaten zor olan kültürel ve sosyal entegrasyonun iki taraf için de (ev sahibi ve misafir) bir tercih gibi algılanmasını engellemektedir.

Ev sahibi toplumun dayanıklılığı: Türk toplumu ülkenin zaten göç eden kişilerce kurulması ve pekiştirilmesi nedeni ile özellikle insani dramlar üzerinden gelişen kitlesel veya bireysel göçlere karş1 empati duyabilmektedir. Bir de gelen göçmenlerin ortak din ve tarih havzasından gelmiş olması, yüksek bir oyla seçilmiş güçlü bir hükümetin göçü yönetiyor olmasının verdiği güven vb. gibi yan etmenler Türk toplumunun göçmenlere karşı dayanıklılığını arttırmaktadir.

2013 yılında Suriye kaynaklı terör örgütlerinin düzenlediği saldırıda 52 vatandaşını kaybetmiş olan Reyhanlı ilçesinin kendi nüfusundan daha fazla sığınmacıyı misafir etmesi ve neredeyse hiçbir sosyal soruna meydan vermeden bu misafirliği yıllardır sürdürüyor olması son derece anlamlıdır (Duruel, 2017, s.61).

Ancak toplumsal kabul ucu açık, sonsuz ve bugünkü hali ile sürdürülebilir bir durum değildir ve son derece kırılgandır. Yani toplumsal kabulün yüksek olması toplumun Suriyelilere yönelik endişeleri olmadığı anlamına gelmemektedir. Hacettepe Üniversitesi Göç ve Siyaset Araştırmaları Merkezi-HUGO tarafından Ekim 2014 yılında yapılan kapsamlı çalışmada, Türk toplumunun Suriyeliler ile arasında çok ciddi bir kültürel mesafe koyduğunu, endişelerin son derece yaygın ve üst düzeyde olduğu, Suriyelilerin bir an önce geri dönmelerini arzu ettikleri ve onlara vatandaşlık verilmesi ihtimaline de çok net biçimde karşı çıktığı gözlenmektedir (Erdoğan, 2016, s.77-78).

Göçü yönetimindeki beceri: Göçle mücadele bağlamında kurumsal olarak AFAD, Göç İdaresi Genel Müdürlüğü gibi kurumsallaşmaların oluşturulması ve Yabancılar ve Uluslararası Koruma Kanunu başta olmak üzere, Geçici Koruma Yönetmeliği (2014), Uluslararası İşgücü Kanunu
(2016) birçok hukuki düzenlemenin hızlı bir biçimde hayata geçirilmesi Türkiye'deki göç yönetimi bakımından oldukça başarılı olduğu görülmektedir. Diğer yandan göç istatistikleri ve yönetimine ilişkin politikaların şeffaf olması yaşanabilecek spekülasyonları, manipülasyonları önlemektedir.

Gelişmiş ülkelerin Türkiye'ye beklediği desteği sağlayamaması göç yönetiminde zorluklara neden olmaktadır. Gelişmiş ülkelerin kriz boyunca ortaya koydukları tavır 2014 başına kadar adeta 'doğu sınırınızı sonuna kadar açın batı sınırını kapatın bize gelmesinler', 2014 yilından sonra ise 'para verelim bize gelmelerine engel olun' şeklinde özetlenebilir (Erdoğan, 2016, s.75).Avrupa Birliği, göç yolları üzerinde bulunan Türkiye'yi bir tampon bölge olarak kullanmak istemektedir. Avrupa Birliği'nin sınırlarını büyük ölçüde mültecilere kapatması nedeniyle, mültecilerin sayısı artmakta ve Türkiye'ye olan maliyetleri yükselmektedir. Dolayısıyla alınacak daha fazla göçmenin Türkiye'de toplumsal, ekonomik ve siyasal iç karışıklıklara neden olma ihtimali artmaktadır (Arınç, 2018, s.1467,1481).

Bir diğer zorluk dünyada küresel ekonomik iş göçü zamanlarının aksine göçün gelişmiş ülkelerce bile istenilmemesidir. Tarihsel olarak uluslararası göçle göçalan ülke olarak daha önce tanışmış ve ekonomik olarak gelişmiş ülkelerde yirminci yüzyıl boyunca asimilasyon, entegrasyon ve çok kültürcülük zinciri üzerinden gelişen devlet-göçmen ilişkilerinin son yıllarda yeniden asimilasyona dönüşü süreci yaşamaktadır (İçduygu vd., 2014, s.64). Yaşanan sıra dişı hareketlilikler Avrupa ülkelerinin yönetimlerinin daha güvenlikçi politikalara yönelmelerine sebep olmuştur. Gelen göç akınlarını dışlaştırma (externalization) yoluna giden Avrupa Birliği, bir taraftan Frontex uygulamaları ile Avrupa kalesinin surlarını yükseltirken, diğer taraftan Türkiye gibi transit ülkelerden geçiş yaşamları tekrar gelir göndermenin pazarlıklarını yapmaktadır (Sağıroğlu, 2016, s.44). Göçmenleri üçüncü ülkeye hukuken yollanamaması, menşe ülkeye vicdanen yollanamaması ve fakat Türkiye'de kalmalarının da artık yönetilemez bir hale gelmesine neden olmaktadir.

Bunun yanında göçmenlerin artık neredeyse tüm dünyada iç politika meselesi haline gelmesi yani göç yönetimini rasyonel alandan siyasal alana taşınması göç yönetiminde karar alma mekanizmaların doğru çalışmasını etkilemektedir.

Türkiye'deki İskân kurumunun, tarım topraklarına yerleştirmedeki ve içgöçteki denetim gücünü özellikle 1960'lı yıllar sonrasında kaybetmeye başladığını söylemek mümkündür. $\mathrm{Bu}$ dönemde, nüfus patlaması ve tarımsal yapıdaki değişikliklerin etkisiyle içgöç hızlanmış ve denetlenemez boyutlara ulaşmıştır (İçduygu vd., 2014, s.157). Dolayısı ile Türkiye'deki iskân kurumunun iç göçü düzenlemesi bakımından henüz 1960'larda etkisini kaybettiği dikkate alındığında geçici koruma altında olan Suriyelilerin, Cumhuriyetin başında yaşanan göçlerde uygulandığı biçimi ile geçici bile olsa iskân edilememekte ve ülkenin tüm illerinde adeta iç göç edercesine seyahat edip, yerleşip, çalışmakta oldukları görülmektedir. ${ }^{3}$

${ }^{3}$ Geçici koruma altında olan yabancılar bulundukları illerde kayıt
altına alınmaktadırlar. Kayıt kotası dolan illere yeni yabancı kaydı 
Tüm bu verilerin 1şı̆ğında Suriyelilerin ev sahibi toplum tarafından 'yıkıcı göçmen' olarak algılanmaya başladığını söylemek mümkündür. Her ne kadar göçlere karşı mukavemeti sağlam olsa bile, Türkiye'nin, Doğu Türkistan protestoları sırasında Çinli zannedilerek Koreli turistlere saldırılması gibi olayların da pek ender rastlanmadı̆̆ toplumsal arka planı bulunmaktadır. Dolayısı ile Suriyelilerin özelinde gelişen bu yıkıcı göçmen algısının Suriyeliler özelinde kalmaması ve tüm yabancıların hatta 'yabancılara benzetilen' vatandaşların bile yıkıcı göçmen olarak görülmesi muhtemeldir. Böylesi durumların oluşmaması veya oluşması durumunda sağlıklı yönetilebilmesi için ev sahibi toplumun olduğu kadar göçmen toplumun da özellikle ev sahibi toplum ve devlete ilişkin, adalet algı ve tutumlarının bilinmesi oldukça önemlidir.

\section{Araştırmanın Metodolojisi}

Araştırmanın konusu ve sorunu: Göç bağlamında akademik veya bireysel yaklaşım, genellikle ve doğal olarak, göç alan ülke insanına ilişkin değerlendirmeler içermektedir. Fakat özellikle suç sosyolojisi bağlamından bakıldığında bireysel veya toplumsal bir çıkar çatışmasında, temelde, olayın en az iki tarafı bulunmaktadır ve çatışmaya konu olayın çözümünde biri diğerinden daha ayrıcalıklı değildir. Bu çalışmada ise madalyonun 'öteki' tarafına yani dış göçle Türkiye'ye gelen ve 'yabancı' olarak görülen insanlara odaklanılmış, onların toplumsal adalet, adli kurumlar ve adli sürece ilişkin algıları, yaşayabilecekleri çıkar çatışmalarındaki muhtemel davranış biçimleri anlaşılmaya çalışılmıştır.

Araştırma evreni Yalova ildir. Yalova hem iç göç hem de dış göç bakımından dikkat çeken illerden birisidir. İç göç bakımından TUIKK verilerine göre 'net göç hızı' kriterinde, özellikle 2011 baz alındığında, Yalova ilinin; 2011 yılında $\% 1,4$ hiz ile 13., 2012 y1lında \%10.2 hiz ile 10., 2103 y1linda \%22,3 hiz ile 4., 2014 yilinda 16,1 hiz ile 5., 2015 y1lında \%10,1 hiz ile 5., 2016 yilında 9,7 hiz ile 10., 2017 yılında 20.2 hiz ile 2. sirada yer almaktadir.

Uluslararası göç bakımından ise Göç İdaresi Genel Müdürlüğü verilerine göre (16.10.2019 itibari ile) Yalova da 16.558 ikamet izinli yabanc1, (17.10.2019 itibari ile) 3.903 geçici koruma kapsamındaki Suriyeli bulunmaktadır. Yalova düzensiz göçmenler bakımında Göç İdaresi Genel Müdürlüğü'nün 5 aşamalı renklendirilmiş haritasında en fazla düzensiz göçmenin bulunduğu mavi renkle (100-1000 kişi) gösterilmektedir. Uluslararası koruma statüsüne sahip kişilere ilişkin istatistikler yayınlanmamaktadır. Ancak sözel olarak görüşülen yetkililer Yalova ilinde 7.000 kadar uluslararası korumaya sahip kişinin olduğunu ifade etmişlerdir. $\mathrm{Bu}$ durumda kayıtlı olan 21.161 kişi bulunmakta bu sayıya düzensiz göçmen statüsündeki yabancılar da eklendiğinde 23.000 kadar bir yabancı nüfusundan bahsetmek mümkün olacaktır. 23.000 yabancı

yapılmamakta diğer illere yönlendirilmektedir. Bulundukları illeri terk ettikleri belirlenen geçici koruma altındaki yabancıların kayıtlı oldukları illere gitmeleri yönünde idari işlemler uygulanmaktadır. Bunun yanında izinsiz il dışına çıkmalarına imkân veren ulaştırma firmalarına idari işlemler yapılmaktadır. Fakat tüm bu idari işlemlerin kayıtlı olduğu ili terk etmek isteyen bir yabancıyı kararından döndürebilecek etkililikte olmadığı görülmektedir. sayıs1 ise TÜİK'in 2018 verisine göre Yalova'nın 262.234 kişi olan nüfusunun \%8.7 sine karş1lık gelmektedir.

Araştırma örneklemi ve alanı: Araştırma evreninde yaklaşık 23.000 kişi bulunmaktadır. Araştırmada yaklaşık her 50 yabancıdan 1'i ile görüşülmesi hedeflenmiştir. Dolayısı ile anketin kapsamı 450 kişilik bir örneklem grubu olarak belirlenmiştir. $\mathrm{Bu}$ örneklem grubuna iki şekilde ulaşılmıştır. Birincisi tanışılan kişilerin, gerekli özellikleri taşıyan diğer tanıştırdıkları ile anket yapılarak kartopu örneklemi (Kümbetoğlu, 2008, s.99) kullanılmıştır. İkincisi Yalova'da yaşayan yabancılar bir küme olarak kabul edilerek ihtiyaç kadar kişi olasılık temelli olarak örnekleme dâhil edilmiştir (Yıldırım ve Şimşek, 2005, s.104-15).Tüm örneklem gönüllü olarak ankete katılmıştır.

Araştırma alanı ise yabancıların Yalova ilinde bulundukları ve anketlerin gerçekleştirildiği mahallelerdir. Yalova'da yabancıların Türkçe haricinde Arapça ve Farsça üzerinden iletişim kurdukları, yaşadıkları alanların seçiminde de (dolayısı ile araştırma alanının seçiminde) bu dillerin merkezi rol oynadığı görülmektedir. Bu bağlamda, Arapça konuşan yabancıların (gözlem verilerine göre $\% 50$ üzeri ${ }^{4}$ ) Bahçeli Evler Mahallesi Fatih Caddesi boyunca sağlı sollu binalarda ve Adnan Menderes, Kazım Karabekir Mahallesinde oturdukları görülmüştür. Bahçeli Evler ve Kazım Karabekir Mahallesinde genellikle BM'ye uluslararası sığınma başvurusu yapan Iraklıların bulunduğu, Adnan Menderes Mahallesinde ekonomik durumları iyi olan kendi aldıkları evde oturmakta olan ve Türkiye'den ikamet tezkeresi alan Iraklılar bulunduğu görülmüştür. Suriyelilerin ekonomik durumu iyi olanlarının genellikle Iraklıların yaşadıkları yerlerde yaşadıkları görülmüştür. Bununla birlikte ekonomik durumları orta ve alt düzeyde olan Suriyelilerin ise İsmet Paşa Mahallesi, Gazi Osman Paşa Mahallesi ve Mustafa Kemal Paşa Mahallesinde yaşamayı tercih ettikleri görülmüştür. Farsça konuşan yabancıların ise Arapça konuşanlar gibi belli bölgelerde toplanmadıkları görülmüştür. Bunun yerine kentin geneline dağılmış olmakla birlikte genellikle Şii ve Hıristiyan inanç temelli toplulukları biçiminde birbirlerine yakın gruplar oluşturdukları görülmüştür.

Araştırmanın veri toplama teknikleri: Çalıșmada veri toplama metodu olarak anket ve gözlem kullanılmıştır. Anket yapılan kişilerin niteliklerinden dolayı anket metodu klasik anlamda kullanılan anket biçimlerinden biraz farklılık arz etmektedir. Çalışmada yapılan anket neredeyse nitel yöntemler ile yerine getirilmiş olsa da ön anket çalışmaları sonrası çalışma bir nicel anket çalışması biçimini almıştır.

Anket çalışmasına başlanılmadan önce bir anket formu hazırlanmış ve deneme için Suriyeli, Afgan, Türkmen ve Iraklı yabancılar ile anket çalışması yapılmıştır. Yapılan anketler sonrası görüşmeler gerçekleştirilerek bu kişilerin ankete verdikleri tepkiler ve eleştiriler üzerine anket formu ve yapılış biçimi yenilenmiştir. Yabancılar tarafindan anketin ilk formuna getirilen eleştirileri aşağıdaki şekilde sıralamak mümkündür.

\footnotetext{
4 Emniyetin yabancılar şubesi Fatih Caddesi yakınlarında bulunduğu ve Yalova'nın da merkezi bir yeri olması ve öncesinde bu caddede Türk vatandaşı Arapların oturuyor olmaları; ilk gelen ekonomik durumu iyi olan görünür göçmenlerin ilk yerleşim yerlerinin burası olmasını mümkün kıldığı anlaşılmaktadır.
} 
1. Görüşmede kişisel soruların en sonda sorulması daha iyi olacaktır. Anketin başında kişisel bilgileri istenilen yabancılar kişisel veya aile güvenlik kaygılarını arttırmakta onları tedirgin etmekte ve bu tedirginlik anketin diğer sorularına verilen cevapları etkilemektedir.

2. Anketin üçüncü bölümü olarak tasarlanan ve mala, şahsa ve topluma karşı suçlarda adli birimlere başvurma veya kendi cezasını verme eğilimlerini gösterir 30 sorunun (ki her soru için müşteki, tanık, cezasını kendim veririm, bir şey yapmam olarak 4 başlik da bulunuyor toplam 120 diyalog gerekiyor) yorucu olduğu ve şahısları anketten soğuttuğu anlaşıldığı için bu bölüm çıkarılmıştır.

3. Üçüncü bölümün çıkarılması birinci bölümdeki bazı soruların detaylandırılması ile aşılmaya çalışılmıștır. Mesela "Sığınmacılar kendi aralarındaki sorunlar ile ilgili adli birimlere giderler mi?" gibi sorusuna önemli olaylarda gider gibi cevap seçenekleri konulması istenilmiştir.

4. Ön anket ve görüşmeler sırasında yabancıların gelir gruplarının farklılık arz ettiği, alt gelir grubu olanların 1500 , orta gelir grubu olanların 1500-3000 ve üst gelir grubunun ise 3000 üzeri aylık gelirleri olanlar olduğu görülmüştür. Anket soruları bu şekilde güncellenmiştir.

5. Yapılacak anketin mutlaka karşılıklı konuşarak ve mümkün olan en kısa şekilde, çalışmanın kritik noktalarına ilişkin verilerin alınmasına olanak tanıyacak şekilde olması gerektiği anlaşılmıştır. Yabancıların ellerine verilecek ve doldurulması beklenilecek anket formunu ya doldurmadıkları ya da boş bıraktıkları görülmüştür.

6. Kesinlikle kayıt cihazı, fotoğraf vb. araçların kullanılmaması tüm notların el ile alınması gerektiği görülmüştür.

7. Yapılan ön görüşmelerde her ne kadar anketin başında çalıșmanın amacı uzun uzun anlatılsa ve görüşme yapılması kabul edilse bile yabanciların sorulara samimi cevap vermediği anlaşılmıştır. Bunun temel nedeninin görüşme yapan kişinin Türk kimliği olduğu, ön görüşme yapılan yabancıların samimi beyanlarından anlaşılmıştır. Ön görüşme sırasında kişisel bir hukukumuzun geliştiği Afgan uyruklu ve Suriye uyruklu iki erkek şahıs yapılan kayıt dışı görüşmede yabancıların Türkler ile yaptıkları görüşmelerde kayıt altına alınma korkusu yaşadıkları hatta geldikleri ülkedeki düşmanlıklarından dolayı bile tedirgin olduklarını dolayısı ile yapılacak görüşmelerde Türklere gerçek duygularını ifade edemeyeceklerini beyan etmişlerdir.

8. Yapılan ön görüşmelerden de anlaşıldığı üzere yabancılar ile yapılacak olan anket çalışmasının katı yapılandırılmış mülakat şeklinde, mutlaka kendi dillerini bilen soydaşlarının da dâhil olması ile ve kendilerini rahat hissettikleri ortamlarda yapılması gerektiği anlaşılmıştır.

9. Yalova'daki yabancıların hemen hemen tamamına Arapça ve Farsça konuşan kişiler üzerinden ulaşılabileceği görülmüş̧ür.

10. Ön anket çalışmasında yabancıların kendi dilini konuşan kadılara karşı daha dürüst, güvenerek ve korkusuz cevap verecekleri ifade edilmiştir.

11.9.maddedeki veri dikkate alınarak Yalova'da bulunan uluslararası bir yardım derneği üzerinden Arapça konuşan Iraklı, Mısırlı ve Farsça konuşan Afgan üç kadın yabancı ile tanışılmıştır. Bu kişilere çalışmanın amacı ve anketin nasıl yapılacağı anlatılmıştır. Sonrasında bu üç kadın ile birlikte anket çalışmasına başlanılmıştır.

12. Fakat anketler sırasında yardımcı olan bu kadınlar bile kendi resimlerini, isimlerini, adreslerini vermek istememişler sadece ön adlarının kullanılmasına müsaade etmişlerdir. Raga (Mısırlı), Dua (Iraklı), Nilüfer (Afgan). 13. Dolayısı ile anket, ülkemizdeki klasik anket çalışmalarından farklı yapılandırılmış mülakat formunun çok sıkı bir versiyonu şeklinde uygulanması mecburiyetinde kalınmıştır.

Anlaşılacağı üzere anket soruları kritik bilgiyi sağlayıcı ve yapılacak çaprazlamalar ile çalışmayı hedefine ulaştırıcı biçimde son şekline kavuşturulmuştur. Yine anket sürecinin dinamik yapısı nedeni ile tek bir yöntem yeterli olmadığı için karma anket uygulanmıştır (Baş, 2006, s.34). Anketlere yüz yüze konuşarak başlanılmış fakat kartopu-zincirleme örneklemin oluşturduğu bir kısım yabancı şahıs ankete telefon ile katılabileceğini ifade etmiştir. Yalova'da ikamet eden ve ankete katılmak için çeşitli nedenleri ile araştırmacı ile buluşamayacak olan bu kişilerin istekleri, verileri sakatlamayacağı için kabul edilmiştir. Anketlerin 387'si yüz yüze görüşme ile 63 tanesi telefon ile görüşmek sureti ile gerçekleştirilmiştir. Geniş aile bile olunsa anket yapılırken bir aileden 2 kişiden fazla görüşülmemiştir. Böylelikle çok daha fazla aileye ulaşılmaya çalışılmıştır. Ayrıca anket yapılırken cinsiyet, ekonomik durum, eğitim durumu, yaş vb. gibi değişkenlerin orantılı olarak dağılmasına dikkat edilmiştir. Örneklem buna göre seçilmiştir.

Anket yapılırken anket formu yabancı şahısların eline verilerek doldurması istenilmemiştir. Bunun temel nedeni soruların içeriğinin anlaşılması için kendilerine detaylı anlatımların yapılması gerekliliğidir. Kendilerine anket teklif edilen ve bunu gönüllü olarak kabul eden kișilere sorular sözlü olarak sorulmuş ve evet-hayır şeklinde ikili veya bekâr-evli-dul şeklinde üçlü cevaplar veya kaç yıldır Türkiye'desin gibi açık uçlu sorular sunularak verdikleri cevaplar forma işlenmiştir.

Bunun yanında anket çalışması yabancıların yoğun olarak yaşadıkları yerlerde ve onlarla sosyal ortamlarını da paylaşacak şekilde yapıldığı için araştırmada gözlem metodu da kullanılmıştır. Araştırma süresince firsat buldukça ortam, ortam içinde oluşan temel davranış ve süreçlere ilişkin ayrıntılı ve tanımlayıcı notlar alınmıştır.

Anket süreci, anket çalışmalarında pek alışık olunmadığı üzere yaklaşık 40 gün kadar sürmüştür. Anket çalışması sırasında katılımcıların mümkün olduğunca fazla soruyu cevaplaması amaçlanmış ve cevap verilmeyen sorular kendilerine yeniden sorulmuş son tahlilde 1srarla cevap vermek istemeyen kişiler olması halinde soru cevapsız bırakılmıştır. Dolaysı ile anket çalışmasında cevap verilmeyen soru sayısı çok azdır.

Araştırma sırasında karşıllaşılan zorluklar: Anket yapılan kişilerde genellikle 'benim karım ne?, bunları neden soruyorsun? Casus musun?' şeklinde ifade bulan ön yargıları bulunmaktadır. Özellikle anket çalışmasının yapıldığ 2019 yılı Eylül ve Ekim aylarında Suriyelilerin evlerine yollanacağı, İstanbul'da kaydı bulunamayan Suriyelilerin kayıtlı oldukları illere gönderilmesine ilişkin haberlerinin ulusal kanallarda yer alması ve Suriye'nin kuzeyine yapılması planlanan sinır ötesi operasyonun yarattığı toplumsal atmosfer yabancıların ankete katılımını zorlaştırmıştır. Ankete gönüllülük esasına göre başlanılsa bile neredeyse her soruyu ayrı ayrı anlatmak ikna etmek gerekmiştir. Anket formlarının doldurulması zaman zaman 20 dakikayı geçmiştir. 
Ankete katılanların cevap vermekte en çok zorlandıkları gözlemlenen sorular: i)sığınmacılar kendi aralarındaki sorunlar ile ilgili adli birimlere gider mi? ii) suça karışan bir sığınmacı kaçmak istese yakalanabilir mi? iii)suça karışan bir sığınmacı teslim olur mu? iv) aylık gelir şeklinde sıralanmaktadır. En kolay cevap verilen sorular ise: i)Hiç adli birimlere gittiniz mi? ii)Türkiye'de kendinizi güvende hissediyor musunuz? iii)Fırsatınız olsa Türkiye'de kalır misınız? olarak sıralanmaktadır.

Bunun yanında erkeklerin kadınlara göre daha hızlı ve rahat cevap verdikleri kadınların çok fazla detay soru sorarak anketi anlamaya çalıştıkları gözlemlenmiştir.

\section{Araştırmanın Verileri}

Araştırma 17 sorunun bulunduğu birinci bölüm ve 15 sorunun bulunduğu ikinci bölümden oluşmaktadır. Birinci bölümde yabancıların kurumsal ve toplumsal adalet algılarını analiz etmeye imkân verebilecek sorular yer alırken ikinci bölümde katılımcıların kişisel özelliklerinin neler olduğunun anlaşılmasına olanak tanıan sorular bulunmaktadır. Bu başlık altında ise öncelikle her soru için katılımcıların verdiği cevaplar; örnekleme, toplumsal adalet algısına ve kurumsal adalet algısına ilişkin veriler paylaşılacak sonrasında araştırma verilerinden uygun çaprazlamalar yaparak örneklem, toplumsal adalet alg1sı ve kurumsal adalet algısı değerlendirilecektir.

\section{Örneklemin Verileri:}

Araştırmaya katılmayı kabul eden 450 kişilik örneklem grubunun özellikleri aşağıda sıralanmıştır. Örneklem her ne kadar yabancı şahısların bulundukları yerlerde rast gele metodu ile seçilmiş olsa bile, çalışma sırasında zaman zaman ara verilmiş ve örneklemin cinsiyet, yaş, ekonomik durum vb. dağılımlarına bakılarak dağılımda eksik olduğu görülen nitelikteki kişilerle anket/görüşme gerçekleştirilmiştir. $\mathrm{Bu}$ şekilde çalışmanın mümkün olan tüm sosyal katmanları kapsaması sağlanmıştır.

Tablo 1: Örneklemin Ülke Dă̆ı̆lımları

\begin{tabular}{|c|c|c|c|c|}
\hline Afganistan & Afrika & Amerika & Azerbaycan & Cezayir \\
\hline 127 & 2 & 1 & 1 & 3 \\
\hline Kuveyt & Mısır & Pakistan & Rusya & Sudan \\
\hline 1 & 28 & 1 & 13 & 1 \\
\hline Eritre & Filistin & Irak & İran & Kırgızistan \\
\hline 4 & 2 & 112 & 65 & 2 \\
\hline Suriye & S.Arabistan & Tataristan & Ukrayna & Ürdün \\
\hline 51 & 23 & 9 & 2 & 2 \\
\hline
\end{tabular}

Araştırmaya 127 Afganistanlı, 112 Iraklı, 65 İranlı, 51 Suriyeli, 28 Misırlı, 23 Suudi Arabistanlı, 13 Rus, 9 Tataristanlı, 4 Eritreli, 2 Ukrayna, Kırgızistan, Afrikalı, Filistinli ve Ürdünlü, 1 Amerikalı, Azerbaycanlı, Kuveytli, Pakistanlı, Sudanlı olmak üzere toplamda 20 farklı ülkeden katılım olmuştur.

Tablo 2: Örneklemin Cinsiyet ve Yaş Dağılımları

\begin{tabular}{cccccccc}
\hline & $\mathbf{1 5 -}$ & $\mathbf{2 6 -}$ & $\mathbf{3 6 -}$ & $\mathbf{4 6 -}$ & $\mathbf{5 6 -}$ & $\mathbf{6 6 -}$ & Toplam \\
& $\mathbf{2 5}$ & $\mathbf{3 5}$ & $\mathbf{4 5}$ & $\mathbf{5 5}$ & $\mathbf{6 5}$ & $\mathbf{7 0}$ & \\
\hline Erkek & 55 & 56 & 42 & 24 & 19 & 1 & 197 \\
\hline Kadın & 54 & 91 & 58 & 31 & 15 & 3 & 252 \\
\hline Trans & & 1 & & & & & 1 \\
\hline Toplam & 109 & 148 & 100 & 55 & 34 & 4 & 450 \\
\hline
\end{tabular}

Araştırmaya 197 erkek, 252 kadın ve 1 trans birey katılmıştır. Türkiye'ye göç veren ülkelerin toplumsal, siyasal, ekonomik vb. gibi sorunlardan kaçmaları nedeni ile Türkiye'de bulunan yabancıların kadın oranın erkeklere göre daha fazla olması beklenen ve anlaşılır bir durum olarak değerlendirilmektedir.

Tablo 3: Örneklemin İş Durumu Tablosu

\begin{tabular}{|c|c|c|c|c|}
\hline Aş̧̧ı & Bahçe İşleri & Bebek Bakıcısı & Bekçi & Boyacı \\
\hline 1 & 8 & 1 & 2 & 2 \\
\hline Hacamatçı & İnşaat & Ticaret & İşçi & İşsiz \\
\hline 1 & 18 & 5 & 2 & 248 \\
\hline Reklamcı & Serbest & Şirket & Tamirci & Temizlikçi \\
\hline 1 & 91 & 2 & 1 & 2 \\
\hline Çocuk Bakıcısı & Emlakçı & Esnaf & Fırın & Garson \\
\hline 1 & 6 & 1 & 2 & 2 \\
\hline Kuaför & Muhasebeci & Mühendis & Öğrenci & Öğretmen \\
\hline 6 & 4 & 2 & 10 & 4 \\
\hline Tercüman & Terzi & Yardım Kuruluşunda Görevli \\
\hline 4 & 22 & \multicolumn{4}{|l}{} \\
\hline
\end{tabular}

Örneklem toplamda 27 farklı iş kolunda çalışanların yanında öğrenci ve işsiz olanlardan olmak üzere 29 kategoriden oluşmaktadır. Yabancıların yarıdan fazlasının işsiz olduğu görülmektedir. İşsiz kategorisini serbest meslek, terzi, inşaat işçisi, kuaför, bahçe işleri ile uğraşanlar, emlakçılık, ticaret, tercüman, öğretmen, bebek bakıcısı, çocuk bakıcısı, esnaf, hacamatçı, reklamcı, tamirci, aşçı ve yardım kuruluşlarında çalışanlar izlemektedir.

Tablo4: Örneklemin Aylık Gelir Durumu Tablosu

\begin{tabular}{lllll}
\hline Aylık Gelir & $\mathbf{0 - 1 5 0 0}$ & $\mathbf{1 5 0 0 - 3 0 0 0}$ & $\begin{array}{l}\text { 3000 } \\
\text { ve } \\
\text { Üzeri }\end{array}$ & Toplam \\
\hline Kişi Sayısı & 207 & 146 & 97 & 450 \\
\hline
\end{tabular}

Örneklem içinde 207 kişinin $0-1500$ arası/alt gelir grubunda, 146 kişinin 1500-3000 arası/orta gelir grubunda, 97 kişinin ise 3000 ve üzeri üst gelir grubunda olduğu görülmektedir.

Tablo 5: Örneklemin Eğitim Durumu

\begin{tabular}{lcccccc}
\hline $\begin{array}{l}\text { Eğitim } \\
\text { Durumu }\end{array}$ & Yok & İlk & Orta & Lisans & $\begin{array}{l}\text { L. } \\
\text { Ustü }\end{array}$ & Toplam \\
\hline Sayı & 46 & 78 & 151 & 135 & 40 & 450 \\
\hline
\end{tabular}

Örneklemin büyük oranda orta ve lisans mezunu olduğu bunu ilkokul, lisansüstü ve okula gitmeyenlerin takip ettiği görülmektedir.

Tablo 6: Örneklemin Türkiye'de Bulunduğu Süre Dağılımları

\begin{tabular}{|c|c|c|c|c|c|}
\hline Süre & $\begin{array}{l}1 \text { gün- } \\
1 \text { yıl }\end{array}$ & $\begin{array}{l}2 \text { yil ve } 3 \\
\text { yil }\end{array}$ & $\begin{array}{l}4 \text { yıl-5 } \\
\text { yıl }\end{array}$ & $\begin{array}{l}6 \text { yil } \\
\text { ve }+\end{array}$ & Toplam \\
\hline Kişi Sayısı & 143 & 182 & 94 & 31 & 450 \\
\hline
\end{tabular}

Örneklem büyük oranda 2 ve 3 yıldır Türkiye'de bulunanlardan oluşmakla beraber bu kategoriyi en fazla 1 yıldır, 4 ve 5 yıldır ve 6 ve üzeri yıllardır Türkiye'de bulunanlar kategorileri takip etmektedir. 
Tablo 7: Örneklemin Türkiye İçinde Değiştirdiği Şehir Sayıları Dağılımları

\begin{tabular}{llllllllllll}
\hline İl Sayısı & $\mathbf{1}$ & $\mathbf{2}$ & $\mathbf{3}$ & $\mathbf{4}$ & $\mathbf{5}$ & $\mathbf{6}$ & $\mathbf{7}$ & $\mathbf{8}$ & $\mathbf{1 0}$ & $\begin{array}{l}\text { Cevap } \\
\text { Yok }\end{array}$ & Toplam \\
\hline Kişi Sayısı & 132 & 88 & 97 & 32 & 23 & 1 & 3 & 1 & 1 & 72 & 450 \\
\hline
\end{tabular}

Örneklemin hepsinin il değiştirdiği anlaşılmaktadır. Bunlardan en fazla 1 il değiştirilmiş olup bu kategoriyi 3 il, 2 il, 4 il, 5 il, 7 il, ve 6,8,10 il değiştirenler izlemektedir.

Tablo 8: Örneklemin Evlilik ve Eşlilik Durumları

\begin{tabular}{llllll}
\hline & Bir & İki & Bekâr & Dul & Cevapsız \\
\hline Erkek & 104 & 9 & 82 & 1 & 1 \\
\hline Kadın & 154 & 55 & 42 & 1 \\
\hline Trans & \multicolumn{5}{l}{1} \\
\hline
\end{tabular}

Örneklemin çok büyük oranda tek evli olduğu bu kategoriyi bekâr olanların ve dul olanların izledikleri görülmektedir.Bunun yanındaözellikle yabancı kadınlar arasında dulların oranın erkeklerden fazla çıkması dikkat çekicidir. Toplumdaki genel kabulün aksine yabancıların çok büyük oranda tek eşli oldukları iki eşli olanların sadece 9 kişi olduğu görülmektedir.

Tablo 9: Örneklemin çocuk sayıları dağılımı

\begin{tabular}{lllllllllllll}
\hline $\begin{array}{l}\text { Çocuk } \\
\text { Sayısı }\end{array}$ & $\mathbf{1}$ & $\mathbf{2}$ & $\mathbf{3}$ & $\mathbf{4}$ & $\mathbf{5}$ & $\mathbf{6}$ & $\mathbf{7}$ & $\mathbf{8}$ & $\mathbf{9}$ & $\mathbf{1 0}$ & $\mathbf{1 1}$ & $\mathbf{1 2}$ \\
\hline $\begin{array}{l}\text { Kişi } \\
\text { Sayısı }\end{array}$ & 34 & 89 & 63 & 37 & 30 & 16 & 4 & 10 & 4 & 3 & 1 & 2 \\
\hline
\end{tabular}

Toplamda 293 kişinin çocuk sahibi olduğu görülmektedir. Çocuk sayılarının genel olarak 2 ve 3 çocukta yoğunlaştığı bunu 1,4 ve 5 çocuk sayılarının takip ettiği görülmektedir. Toplumda genel kabul görüldüğü üzere yabancıların çocuk sayılarının çok fazla olmadığı anlaşılmaktadır.

Tablo 10: Örneklemin Türkçeye Hâkimiyeti

\begin{tabular}{cccccc}
\hline & Az & Orta & İyi & Çok İyi & Cevapsız \\
\hline Okuma & 265 & 80 & 64 & 40 & 1 \\
\hline Yazma & 270 & 76 & 63 & 41 & \\
\hline $\begin{array}{c}\text { Duyulanı } \\
\text { Anlama }\end{array}$ & 142 & 100 & 117 & 89 & 2 \\
\hline Konuşma & 157 & 89 & 117 & 87 & \\
\hline
\end{tabular}

Örneklemin Türkçe okuma yazmasının genellikle az olduğu, çok iyi okuma ve yazma bildiğini ifade edenlerin 40 ve 41 kişi oldukları, fakat Türkçe duyulanı anlama ve konuşmada bu sayların neredeyse iki katına çıktıkları görülmüştür. Dolayısı ile dilin akademik değil daha ziyade gündelik kullanımda öğrenildiği anlaşılmaktadır.

Tablo 11: Örneklemin Adli Birimlere Gitme Dağılımları

\begin{tabular}{lccccc}
\hline $\begin{array}{l}\text { Adli } \\
\text { Birimlere } \\
\text { Gitme } \\
\text { Durumu }\end{array}$ & Gitmedim & Müşteki & Şüpheli & Tanık & Toplam \\
\hline $\begin{array}{l}\text { Kişi } \\
\text { Sayısı }\end{array}$ & 363 & 42 & 19 & 26 & 450 \\
\hline
\end{tabular}

Örnekleminden 363 kişi adli birimlere gitmemişken, 87 kişi müşteki, şüpheli ve tanık olarak adli sistem ile temas etmiştir.

\section{Yabancıların Kurumsal Adalet Algılarına ilişkin Veriler:}

Kurumsal adalet kavramı ile kolluk, savcılık ve mahkeme gibi adli süreci oluşturan kurumlar kastedilmektedir.

Ankete katılan yabancıların kurumsal adalet algılarını gösteren sorulara tüm örneklem bazında 450 kişinin verdikleri cevaplar aşağıdaki gibidir.

Adli birimlere gittiğinizde kendinizi ifade edebileceğinize inan1yor musunuz? Sorusuna \%79,11 evet, \%20,66 hayır yanıtını vermiş olup \% 0,22 si cevap vermemiştir.

Geldiğiniz ülkede serbest olup burada suç olan fiiller var mı? Sorusuna \%69,33 evet, \% 30,66 hayır cevabını vermiştir.

Adli birimlere müracaat etme veya etmeme kararını nasıl alırsınız? Sorusuna \%41,77 kendim alırım derken \% 58,22'si yakınlarımla görüşerek alırım cevabını vermiştir.

Sığınmacılar kendi aralarındaki sorunlar ile ilgili adli birimlere giderler mi? Sorusuna \%35,11 gider, \% 24 gitmez, \% 40,88 ise önemli olaylarda gider cevabını vermiştir.

Sığınmacılar Türklerle arasındaki sorunlar ile ilgili adli birimlere giderler mi? Sorusuna \%41,55 gider, $\% 19,33$ gitmez derken $\% 39,11$ ise önemli olaylarda gider cevabını vermiştir.

Bir sığınmacı ile sorun yaşasan adli birimler sana adil davranır mi? Sorusuna \%79,77 evet gider derken \%20,22 si hayır gitmez cevabını vermiştir.

Bir Türk'le sorun yaşarsan adli birimler sana adil davranır mı? Sorusuna \% 70,22 evet adil davranır derken \% 29,77 ise hayır adil davranmaz cevabını vermiştir.

Başka sığınmacıların suçlarından dolayı Adli birimler size karşı tavır alabilir mi? Sorusuna \%32 evet derken \%68 ise hayır cevabını vermiştir.

Suça karışan bir sığınmacı kaçmak istese yakalanabilir mi? Sorusuna \%74,22 evet cevabını verirken \% 25,77 ise hayır cevabını vermiştir.

Suça karışan bir sığınmacı teslim olur mu?Sorusuna \% 62,22 evet derken \% 37,77 ise hayır cevabını vermiştir.

Adli sürecin adil olmadığına inanırsan nasıl davranırsın? Sorusuna \% 90,88 bir üst mahkemeye giderim, \% 8,88 cezasını kendim veririm derken sadece \% 0,22 soruyu cevapsız bırakmıştır.

Yabancılara karşı toplumsal bir tepki ile karşılaştığınızda devletin (Adli/İdari sistemin) sizi koruyabileceğine inanıyor musunuz? Sorusuna \% 69,11 evet, \% 30,66 hayır derken \% 0,22 kişi soruyu cevapsız bırakmıştır.

\section{Yabancıların Toplumsal Adalet Algılarına ilişkin Veriler:}

Toplumsal adalet kavramı ile ev sahibi toplumun adli konulardaki davranış biçimi kastedilmektedir. 
Başka sığınmacıların suçlardan dolayı Türk toplumu size karşı tavır alabilir mi? Sorusuna \%57,33evet derken \% 42,66 ise hayır cevabını vermiştir.

Suç mağduru (yani maddi/manevi zarara uğratılma korkusu) olma korkusu yaşıyor musunuz? Sorusuna \%5,11 evet, sığınmacılardan tedirgin oluyorum, $\% 14,88$ evet, ülke vatandaşlarından tedirgin oluyorum derken $\% 80$ ise hayır cevabını vermiştir.

Türkiye'de kendinizi güvende hissediyor musunuz? Sorusuna \%93,33 evet derken \% 6,66 ise hayır cevabını vermiştir.

Fırsatınız olsa Türkiye'de kalır mısınız? Sorusuna \%69,77 evet, \%29,77 hayır derken sadece \% 0,44 cevap vermemiştir.

\section{Araştırmanın Verilerinin Değerlendirilmesi}

\section{Örneklem Verilerin Değerlendirilmesi:}

Yalova gibi hem coğrafi olarak geniş bir alanı kaplamayan hem de nüfus bakımından yoğunluğun bulunmadığ1 bir ildeki tesadüfi örneklemde 20 farklı ülkeden katılımcının olması şaşırtıcı bulunmuştur. Fakat konuşulan dillere göre bakıldığında 227 kişinin Arapça konuşan ülkelerden 223 kişinin ise yoğunlukla farsça konuşan Afgan ve İranlı olmakla birlikte diğer dilleri konuşan ülkelerden geldiği anlaşılmıştır.

Görünür göçmenlerin/yabancıların çoğunluğunun Arapça konuştukları anlaşılmıştır. Bu durum yerliler tarafından yabancının aynı zamanda 'Arap' ile eş değer algılandı̆̆ dolayısı ile gerçekte uyrukları ne olursa olsun oluşabilecek yabancı karşıtlığının çok kolay bir biçimde 'Arap karşıtlı̆̆ı'na dönüşebilme potansiyeli taşımaktadır.

Çalışma 20 farklı ülkeden kişileri kapsamasına karşın araştırma evreni içinde yabancıların dünyasında belirleyici olanın öncelikle dil sonrasında din olduğu görülmüştür. Türkçe haricinde, temel olarak Arapça ve Farsça dillerinde iletişim kurdukları ve bu iki dilin yabancıların ikamet, sosyalleşme, çalışma vb. gibi gündelik yaşamdaki tercihlerini yakından belirlediği anlaşılmıştır. Bu iki dilden birini bilen bir yabancı, Türkçeye aşina olmasa bile, rahatlıkla sosyal, ekonomik, kültürel yaşantısını sürdürebilmektedir. Yabancıların Türkiye'de ülkelerindeki farklıları bırakarak görece bir dayanışma içinde yaşadıkları gözlemlenmesine karşın görüşmeler sırasında, dini anlamda 'Şii ve Sünni' olanların birbirileri ile mesafeli durdukları gözlemlenmiştir.

Arapça konuşan ülkelerden yabancıların Yalova iline (2011 y1lının çok öncesinden beri) yoğun olarak geldikleri kısa ve uzun süreli kaldıkları, yerliler ile Arapların birbirlerine aşina oldukları anlaşılmıştır. Yalova ili ile uzun süredir temasta olan Arap kökenli yabancıların genellikle ekonomik durumları iyi olan kişiler olduğu, Yalova merkez ve Termal ilçesinde ikamet ettikleri görülmüștür. Araştırma sırasında Arapça konuşan yabancıların ekonomik durumu iyi olanlarının il merkezi ve Termal ilçesinde, ekonomik durumu orta olanlarının Çınarcık ve Çiflikköy ilçelerinde yoğunlaştıkları görülmüştür. Yeni gelen (savaştan kaçan Suriye, Irak vb.) Arap nüfusun var olan bu sosyal ağ üzerinden alan bulduğu anlaşılmaktadır. Arapça merkezinde gelișen ortak dil ve kültür, yabancı bir ülkede olmanın verdiği dayanışma duygusu ile Arapça konuşan yabancıların fiziksel birbirine yakın mekanlarda kendi sosyal alanlarında, Türkçeye ve Türk halkına entegrasyon kaygısı ve ihtiyacı hissetmeden kamusal alanlarda yaşadıkları, hatta mümkün olduğunca yerlilere temas etmeden yaşama gayreti içinde oldukları görülmüştür. $\mathrm{Bu}$ durum 'getto'nun tanımına uymasa bile sosyal izalasyonun devam etmesi durumunda bunu mekânsal bir ayrışmanın takip edebileceği anlaşılmaktadır. Çalışma sırasında Arapça konuşanlar nerede bulunabilir diye sorulduğunda yerli halkın 'Arap parkı, Arap apartmanı, Arap sokağı' vb. gibi tanımları çok sık ve doğal bir biçimde kullandıkları fark edilmiştir. Bahsedilen yerlere gidildiğinde ise gerçekten de salt Arapça konuşanların bulunduğu ve geldikleri yerdeki yaşamlarının mümkün olabilen bir 'replikasını' zımni bir imece ile inşa ettikleri, yerlilerin de buralara 'ihtiyatlı bir kabul ile mesafeli durdukları’ gözlemlenmiştir.

Araştırmaya başlanılmadan önce en fazla yabancı göçü veren ülkenin Suriye olacağı düşünülmekteydi fakat araştırma sonucunda Afganistanlıların çok daha fazla çıktığ1 görülmüştür. Fakat buna karşın Farsça konuşanların Arapça konuşanlar gibi yakın lokasyonlarda oturmadıkları ve mümkün olduğunda kamusal alanlarda sosyalleşmedikleri görülmüştür. Farsça konuşanların genel olarak şehrin ve ilçelerin çeperlerinde dağınık bir biçimde ikamet etmekte oldukları ve kamusal alandan ziyade ev, lokal vb. gibi kapalı alanlarda birbirleri ile sosyalleştikleri gözlemlenmiştir.

Tablo 12: Gelir Durumunun Ülke dağılımları

\begin{tabular}{|c|c|c|c|c|c|c|}
\hline Sırası & Ülkesi & $\mathbf{3 0 0 0}+$ & Ülkesi & $\mathbf{1 5 0 0 - 3 0 0 0}$ & Ülkesi & $\mathbf{0 - 1 5 0 0}$ \\
\hline $\mathbf{1}$ & Irak & 41 & Irak & 45 & Afganistan & 110 \\
\hline $\mathbf{2}$ & S.Arabistan & 19 & İran & 23 & Iran & 31 \\
\hline $\mathbf{3}$ & Suriye & 13 & Suriye & 23 & Irak & 26 \\
\hline $\mathbf{4}$ & Iran & 11 & Misir & 16 & Suriye & 15 \\
\hline $\mathbf{5}$ & Misır & 5 & Afganistan & 14 & Misir & 7 \\
\hline $\mathbf{6}$ & Afganistan & 3 & Rusya & 9 & Tataristan & 5 \\
\hline $\mathbf{7}$ & Cezayir & 2 & Tataristan & 4 & Rusya & 4 \\
\hline $\mathbf{8}$ & Kuveyt & 1 & S.Arabistan & 3 & Eritre & 3 \\
\hline $\mathbf{9}$ & Ürdün & 2 & Ukrayna & 2 & Afrikalı & 1 \\
\hline $\mathbf{1 0}$ & & & Kirguzistan & 2 & Cezayir & 1 \\
\hline $\mathbf{1 1}$ & & & Afrikalı & 1 & Filistin & 1 \\
\hline $\mathbf{1 2}$ & & & Amerika & 1 & Pakistan & 1 \\
\hline $\mathbf{1 3}$ & & & Azerbaycan & 1 & Sudan & 1 \\
\hline $\mathbf{1 4}$ & & & Eritre & 1 & S.Arabistan & 1 \\
\hline $\mathbf{1 5}$ & & & Filistin & 1 & & \\
\hline
\end{tabular}

Üst gelir durumlarına bakıldığında yabancılar içinde geliri en çok olanların Iraklılar, Suudi Arabistanlılar ve Suriyeliler olduğu görülmektedir. Dil baz alındığında ise yabancılar arasında gelir düzeyi en fazla olanların açık ara Arapça konuşanlar olduğu anlaşılmaktadır. Üst gelir grubunda bulunan 41 Iraklının $(13$ işsiz kadın haricindekiler) genellikle serbest meslek (14 kişi)ile uğraştıkları, 19 S.Arabistanlının $(10$ işsiz kadın haricindekiler) genellikle serbest meslekle (5 kişi)uğraştıkları, Suriyelilerin (1 işsiz kadın haricindekilerin) ise serbest meslek (5 kişi) ve inşaat işi (3 kişi) ile uğraştıkları görülmektedir. Üst gelir grubunda Arapça konuşan yabancıların ağırlıkta olduğu anlaşılmaktadır.

Orta gelir durumunda ise Irak, İran, Suriye, Misır ve Afganistan'ın başı çektikleri görülmektedir. Orta gelir 
durumu Arapça konuşan ve diğer dilleri konuşanlar tarafından neredeyse yarı yarıya paylaşılmış gibidir.

Alt gelir grubunda ise Afganistan açık ara birinci sıradadır ve onu İran, Irak ve Suriye izlemektedir. Alt gelir grubunda bulunan Afganlardan 69 kişinin işsiz, 11 kişinin terzi, 10 kişinin öğrenci, 10 kişinin inşaat işçisi, 8 kişinin bahçe, 1 kişinin bekçi olduğu görülmektedir. İranlılardan 22 kişinin işsiz, 4 kişinin terzi, 2'şer kişinin serbest meslek ve garson, 1 kişinin emlakçı olduğu görülmektedir. Iraklıklardan 19 kişinin işsiz, 4 kişinin serbest meslek, 2 kişinin öğretmen, 1 kişinin tercüman olduğu görülmektedir. Suriyelilerden ise 13 kişinin işsiz, 1 kişinin tamirci ve 1 kişinin yardım kuruluşunda çalışan olduğu görülmektedir. Alt gelir grubunda Farsça konuşan yabancıların ağırlıkta olduğu anlaşılmaktadır.

Şehrin en merkezi caddelerinden olan Fatih Caddesinde bulunan iş yerlerinin \%60 kadarının, Gazi Paşa Caddesinde ise $\% 30$ kadar iş yerinin Arapça konuşan kişilerce işletildikleri bunların bir kısmının yerli (Siirtli vb.) bir kısmının ise yabancı uyruklu oldukları anlaşılmıştır. Öyle ki Arapça konuşan yabancılar kendi ekonomik alanlarını (sokak, semt vs.) yaratmak yerine var olan ekonomik alanları kendi lehlerine dönüştürmüştür. Yerli esnaf bile talebe karşılık vermek bakımından Arapça bilen çalışanlar istihdam etmektedir.

Arapça konuşan yabancıların Arapça bilen yerlilerle ekonomik anlamda 'kazan kazan' ilişkisi içinde oldukları fakat başlangıçta Arapça bilen yerlilerce yapılan emlakçılık, ticaret vs. hizmetlerin artık yabancilar tarafindan da yapıldığı anlaşılmıştır. Iraklıların ve Suudilerin genelde işveren Suriyelilerin ise işçi durumunda olduğu gözlemlenmektedir. Arapça konuşanların inşaat işçisi, firıncı vb. gibi ağır işleri tercih etmedikleri çoğunlukla ticaretle uğraştıkları gözlemlenmiştir. Arapça konuşanların kazandıkları parayı kamusal alanlarda eğlence, yemek vb. için harcayabildikleri ve ticari teşebbüslerde bulundukları görülmüştür. Arapça konuşan yabancıların (adalet, sağlık vb. hariç) neredeyse tüm talepleri yine Arapça konuşan yabancılar marifeti ile karşıllanmaktadır.

Farsça konuşan yabancılar, Arapça konuşanların sahip oldukları ekonomik sosyal ağ ve firsatlardan yoksun oldukları için, çoğunlukla çalışan konumundadır. Farsça konuşanların genellikle Farsça konuşanların ya da yerlilerin yanında çalıştıkları, ağır işlerde çalışmaktan çekinmedikleri, kazandıkları paraları temel insani ihtiyaçlar dışında harcamadıkları, teşebbüsten ziyade birikim yaptıkları gözlemlenmiştir.

Fakat araştırma sırasında çok dikkat çeken bir unsur olarak farsça konuşan yabancıların şehrin çeperlerinden köylerine doğru bir iş göçü içinde oldukları gözlemlenmiştir. Bu durum geçmişte göçmenlere (Türk ve Türk kültürüne bağlı olanlara) resmi, organize olarak sunulan iskân politikasının bu sefer yabancilar tarafindan gayri resmi, organizasyonsuz keşfedilen ve gerçekleşen biçimi şeklindedir. Farsça konuşan yabancıların çobanlık ve tarım işleri için, çocukları yanında olmayan ve işleri çeviremeyen yerlilere yardım ettikleri, yerlilerce 'gayretli ve kaprissiz' algılandıkları ve yerli işverenin kabul etmesi halinde ailelerini bu lokasyonlara taşıdıkları gözlemlenmiştir. İhtiyarlayan köyler için aileleri ile birlikte gelen yabancı genç göçü, köylerin geleceği noktasında ilginç sonuçlar yaratabilecek toplumsal bir dönüşüm potansiyeli taşımaktadır. Burada çalışan yabancı işçiler ile yapılan görüşmelerde köyleri ailece kalabilecekleri, risksiz, güvenli ve ekonomik alanlar olarak gördükleri anlaşılmaktadır. Henüz nüfuslarının az ve dışlanmalarının kolay olduğu köyde yaşayan yabancıların kentte yaşayanlara göre (ekonomik ve kültürel anlamda) yaşanılan yere daha fazla entegre oldukları gözlemlenmiştir.

Bunun dışında İstanbul, Kocaeli ve Bursa gibi şehirlerin yabancı kotalarının dolması ve burada ikametin yasal olarak sıkıntılı olmasından dolayı, yabancıların, bu illerin ortasında bulunması nedeni ile Yalova'ya yerleşmekte ve çevre büyük şehirlerde düzenli veya düzensiz çalışmaya gitmekte oldukları görülmüştür.

Tablo 13: Aylık Gelir Durumu Cinsiyet Dağılımları

\begin{tabular}{ccccc}
\hline & Erkek & Kadın & Trans & Toplam \\
\hline $\mathbf{0 - 1 5 0 0}$ & 75 & 131 & 1 & 207 \\
\hline $\mathbf{1 5 0 0 - 3 0 0 0}$ & 68 & 78 & & 146 \\
\hline $\begin{array}{c}\mathbf{3 0 0 0} \text { ve } \\
\text { Üzeri }\end{array}$ & 54 & 43 & & 97 \\
\hline Toplam & 197 & 252 & 1 & 450 \\
\hline
\end{tabular}

Tablo 14: Cinsiyete Göre Yapılan İlk 8 İş

\begin{tabular}{ccccc}
\hline Sıra & \multicolumn{2}{c}{ Erkekler } & \multicolumn{2}{c}{ Kadınlar } \\
\hline $\mathbf{1}$ & Serbest & 71 & İssiz & 183 \\
\hline $\mathbf{2}$ & İşsiz & 64 & Serbest & 20 \\
\hline $\mathbf{3}$ & İnşaat & 18 & Terzi & 15 \\
\hline $\mathbf{4}$ & Terzi & 7 & Bahçe & 5 \\
\hline $\mathbf{5}$ & Emlakçı & 5 & Kuaför & 5 \\
\hline $\mathbf{6}$ & Öğrenci & 5 & Öğrenci & 5 \\
\hline $\mathbf{7}$ & Bahçe & 3 & Öğretmen & 3 \\
\hline $\mathbf{8}$ & Muhasebeci & 3 & Ticaret & 3 \\
\hline
\end{tabular}

Kadınlar düşük gelir grubunda yoğunlaşırken, orta gelir getiren işlerde erkeklere nazaran daha fazla iş bulabildikleri fakat yine de yüksek gelirli işlerin daha ziyade erkekler tarafından yapıldığı anlaşılmaktadır. Fakat burada ifade edilmesi gereken önemli bir nokta anketler sirasında yapılan görüşmelerde ortaya çıkmıştır. Kadınların gelirleri çoğunlukla istihdamdan ziyade eşlerinden aldıkları veya eşlerinden kendilerine kalan aylıklardır. İşsiz olduğunu ifade eden 183 kadından (toplam işsiz sayısı 248 kişidir) 103 'ü 0-1500, 50'u 1500-3000 ve 30'u 3000 ve üzeri aylık gelirleri olduklarını ifade etmişlerdir. İşsiz olduğunu ifade eden 64 erkek 39'u 0-1500, 14'ü 1500-3000, 11'i 3000 ve üzeri gelire sahiptir. Yapılan görüşmelerden anlaşıldığı üzere işsiz olduğunu söyleyen ve 3000 üzeri geliri olan 11 erkek, ülkelerinden emekli olabilen, ailelerinden veya birikimlerinden gelirleri olan kişilerdir. $\mathrm{Bu} 11$ erkeğin ülke ve yaş dağılımlarına bakıldığında, 21 ile 59 yaşları arasında olan 5 Irak, 2 İran, 1 Misır ve S. Arabistan uyruklu oldukları görülmektedir.

Örneklemin eğitim durumu için verdiği bilgiler kendi kaynak ülkedeki eğitim durumlarıdır. Çünkü 345'i Türkçeyi okumada az ve orta, 64'ü iyi, 40'1 çok iyi olduklarını ifade etmişlerdir. 
Tablo 15: Ülkelere Göre Eğitim Durumu Dağılımı

\begin{tabular}{|c|c|c|c|c|c|c|c|c|c|}
\hline \multicolumn{2}{|c|}{ 0kulsuz } & \multicolumn{2}{|l|}{ İlk } & \multicolumn{2}{|c|}{ Orta } & \multicolumn{2}{|c|}{ Lisans } & \multicolumn{2}{|c|}{ Lisans Üstü } \\
\hline Ülke & Kişi Sayıs & Ülke & işi Sayl & Ülke & Kiși Sayıs & Ülke & iși Saỵ & Ülke & Kişi Sayıs \\
\hline Afganistan & 26 & Irak & 23 & Irak & 45 & Afganistan & 50 & İran & 21 \\
\hline Irak & 6 & Tataristan & 6 & Afganistan & 31 & Irak & 33 & Afganistan & 10 \\
\hline İran & 4 & S. Arabistan & 4 & Suriye & 26 & İran & 23 & Irak & 5 \\
\hline Suriye & 4 & Rusya & 3 & İran & 14 & Misir & 20 & S.Arabistan & 2 \\
\hline Tataristan & 2 & Ukrayna & 2 & S. Arabistan & 11 & S. Arabistal & 5 & Cezayir & 1 \\
\hline Enitre & 1 & Suriye & 21 & Misir & 7 & Rusya & 2 & Rusya & 1 \\
\hline Filistin & 1 & \begin{tabular}{|l|} 
Afganistan \\
\end{tabular} & 10 & Rusya & 6 & Amerika & 1 & & \\
\hline Rusya & 1 & İran & 3 & Eritre & 3 & Cezayir & 1 & & \\
\hline S. Arabistan & 1 & Afrikalı & 2 & Krrgzistan & 2 & & & & \\
\hline & & Azerbaycan & 1 & Cezayir & 1 & & & & \\
\hline & & Kuveyt & 1 & Filistin & 1 & & & & \\
\hline & & Misir & 1 & Pakistan & 1 & & & & \\
\hline & & Ürdün & 1 & Sudan & 1 & & & & \\
\hline & & & & Tataristan & 1 & & & & \\
\hline & & & & Ürdün & 1 & & & & \\
\hline
\end{tabular}

Ülkelere göre eğitim durumu tablosuna bakıldığında ve aylık gelir dağılımı tablosu ile karşılaştırıldığında yabancıların Türkiye'deki ekonomik durumları ile eğitim durumlarının paralel olmadığı görülmektedir. Aylık gelirleri en az olan Afgan ve İranlıların eğitim durumlarının daha fazla olduğu görülmektedir. Dolayısı ile yabancıların Türkiye'deki ekonomik durumlarına etki eden faktörlerin bireysel akademik başarıdan ziyade ekonomik girişimciliğe imkân veren ortak dil ve ortak nüfus sayısı gibi toplumsal faktörler olduğu anlaşılmaktadır. Diğer yandan eğitim alan kadınların ve erkeklerin eğitim durumlarının birbirlerine çok yakın oranlarda olduğu fakat hiç okula gitmemiş olan kadınların okula gitmemiş erkeklere göre çok daha fazla olduğu görülmektedir.

Tablo 16: Cinsiyete Göre Eğitim Durumu

\begin{tabular}{ccccc}
\hline & Erkek & Kadın & Trans & Toplam \\
\hline İlk & 30 & 48 & & 78 \\
\hline Lisans & 75 & 60 & & 135 \\
\hline $\begin{array}{c}\text { Lisans } \\
\text { Üstü }\end{array}$ & 19 & 20 & 1 & 40 \\
\hline Orta & 64 & 87 & & 151 \\
\hline Okulsuz & 9 & 37 & & 46 \\
\hline Toplam & 197 & 252 & 1 & 450 \\
\hline
\end{tabular}

Eğitim durumu ile yaş çaprazlandığında tüm yaş kategorilerinde benzer eğitim durumları olduğu belirgin bir farklılık olmadığı görülmektedir.

Tablo 17: Eğitim Durumu ve Aylık Gelir

\begin{tabular}{ccccc}
\hline & $\begin{array}{c}\mathbf{0 -} \\
\mathbf{1 5 0 0}\end{array}$ & $\begin{array}{c}\mathbf{1 5 0 0 -} \\
\mathbf{3 0 0 0}\end{array}$ & $\begin{array}{c}\mathbf{3 0 0 0} \\
\text { ve }+\end{array}$ & Toplam \\
\hline Yok & 32 & 10 & 4 & 46 \\
\hline İlk & 38 & 27 & 13 & 78 \\
\hline Orta & 57 & 56 & 38 & 151 \\
\hline Lisans & 54 & 44 & 37 & 135 \\
\hline $\begin{array}{c}\text { Lisans } \\
\text { Üstü }\end{array}$ & 26 & 9 & 5 & 40 \\
\hline Toplam & 207 & 146 & 97 & 450 \\
\hline
\end{tabular}

Aylık gelirin eğitim durumuna doğrudan bir etkisi görülmemiştir. 26 yüksek lisans mezunu 0-1500 TL arasında kazanırken, ortaokul mezunu 38 kişi 3000 TL üzeri kazanmaktadır.

Türkiye'de kalma sürelerinin ülkelere göre dağılımlarına bakıldığında sıra ile en uzun Türkiye'de kalan menşe ülkelerin Suriye, Irak, Afganistan olduğu görülmektedir.

Tablo 18: Türkiye'de Kalma Sürelerinin Ülkelere Göre Dağılımı

\begin{tabular}{|c|c|c|c|c|c|c|c|}
\hline Ülke & \begin{tabular}{|c|}
1 Gün-1 \\
Yll
\end{tabular} & Ülke & $2-3 \mathrm{YII}$ & Ülke & $4-5 \mathrm{Yll}$ & Ülke & $\begin{array}{l}6 \mathrm{Yll} \\
\mathrm{Ve}+\end{array}$ \\
\hline Afganistan & 53 & Afganistan & 62 & Irak & 40 & Suriye & 14 \\
\hline İran & 28 & Irak & 41 & Suriye & 23 & Irak & 10 \\
\hline Irak & 21 & İran & 33 & Afganistan & 9 & Afganistan & 3 \\
\hline S. Arabistan & 21 & Misir & 13 & Misir & 7 & İran & 1 \\
\hline Misir & 7 & Suriye & 13 & Rusya & 6 & Kurguzistan & 1 \\
\hline Eritre & 4 & Rusya & 6 & Tataristan & 4 & Misir & 1 \\
\hline Cezayir & 3 & Tataristan & 5 & İran & 3 & Rusya & 1 \\
\hline Ürdün & 2 & S.Arabistan & 2 & Afrikalı & 1 & & \\
\hline Amerika & 1 & Ukrayna & 2 & Sudan & 1 & & \\
\hline Filistin & 1 & Afrikalı & 1 & & & & \\
\hline Kuveyt & 1 & Azerbaycan & 1 & & & & \\
\hline \multirow[t]{3}{*}{ Suriye } & 1 & Filistin & 1 & & & & \\
\hline & & Kırgızistan & 1 & & & & \\
\hline & & Pakistan & 1 & & & & \\
\hline
\end{tabular}

Yabancıların Türkiye'de kalma sürelerinin gelir dağılımına göre tablosuna baktığımızda 3000 üzeri geliri olan 41 kişinin en fazla 1 yıldır Türkiye'de olduğu görülmektedir. Bu kişilerin ülke dağılımlarına bakıldığında sırası ile Suudi Arabistan (18), Irak (11), İran (5), Cezayir (2), Misır (2), Ürdün (2), Kuveyt (1) olduğu görülmektedir. Yine bu 41 kişinin kaç il değiştirdiğine bakıldığında 21 'nin doğrudan Yalova'ya geldiği buna tek il değiştirenleri eklediğimizde 31'inin bir il değiştirerek veya doğrudan şehre geldikleri görülmektedir. Bu sonuçlar yine göç teorilerinden sosyal ağ teorisini desteklemekte ekonomik durumu iyi olan Arapların şehri önceden bilerek geldiklerini göstermektedir.

Tablo 19: Kalma Süreleri ve Gelir Dağglımları

\begin{tabular}{llllllll}
\hline & $\begin{array}{l}\text { 0- } \\
\mathbf{1 5 0 0}\end{array}$ & $\begin{array}{l}\mathbf{1 5 0 0 -} \\
\mathbf{3 0 0 0}\end{array}$ & $\begin{array}{l}\text { 3000 } \\
\text { ve }+\end{array}$ & $\begin{array}{l}\text { 0- } \\
\mathbf{1 5 0 0}\end{array}$ & $\begin{array}{l}\mathbf{1 5 0 0 -} \\
\mathbf{3 0 0 0}\end{array}$ & $\begin{array}{l}\mathbf{3 0 0 0} \\
\text { ve + }\end{array}$ \\
\hline $\begin{array}{l}\mathbf{2 - 3} \\
\text { yıl }\end{array}$ & 99 & 65 & 18 & $\begin{array}{l}\text { 6 ve } \\
+\end{array}$ & 7 & 11 & 13 \\
\hline $\begin{array}{l}\mathbf{1} \\
\text { gün- } \\
\mathbf{1} \text { yll }\end{array}$ & 76 & 26 & 41 & $\begin{array}{l}\mathbf{4 - 5} \\
\text { yıl }\end{array}$ & 25 & 44 & 25 \\
\hline
\end{tabular}

Kalma süresi ve Türkçeye hâkimiyet arasındaki ilişkilere baktığımızda kalma süresi arttıkça duyulanı anlama ve konuşma becerilerinin geliştiği fakat okuma ve yazma becerilerinin aynı hızda kazanılamadığı görülmektedir. Bunun sebebi gelenlerin dili eğitim öğretim sistemi içinde değil günlük yaşam içerisinde öğrenmeleridir. Göçün ikinci neslinde de bu oranların değişmesi beklenebilir.

Bunun yanında yabancıların çok sık il değiştirdikleri anlaşılmaktadır. 
Tablo 20: Kaldıkları Sürelere Göre Değiştirilen İl Sayıları

\begin{tabular}{|c|c|c|c|c|c|c|c|c|c|c|c|}
\hline & & Cevap Ve & renl & erin & Değ & iştir & dikle & eri I & Il $\mathrm{S}$ & ayı & ları \\
\hline Süre & $\begin{array}{l}\text { Kişi } \\
\text { Sayısı }\end{array}$ & Cevapsız & 1 & 2 & 3 & 4 & 5 & 6 & 7 & 8 & 10 \\
\hline $\begin{array}{l}1 \\
\text { gün- } \\
1 \text { yıl }\end{array}$ & 143 & 43 & 30 & 35 & 29 & 2 & 2 & & 2 & & \\
\hline $\begin{array}{l}2 \text { ve } \\
3 \text { yıl }\end{array}$ & 182 & 25 & 65 & 26 & 36 & 17 & 11 & 1 & & & 1 \\
\hline $\begin{array}{l}4 \\
\text { yil-5 } \\
\text { yll }\end{array}$ & 94 & 4 & 31 & 26 & 18 & 5 & 8 & & & 1 & \\
\hline $\begin{array}{l}6 \text { yll } \\
\text { ve }+\end{array}$ & 31 & & 6 & 1 & 14 & 8 & 2 & & & & \\
\hline
\end{tabular}

En sık il değiştiren kişilerin ise Afganistan, Irak, İran, Mısır, Suriye olduğu görülmektedir.

Tablo 21: En Sık İl Değiştiren İlk 5 Ülke Sıralaması

\begin{tabular}{lllllllllll}
\hline İ Sayısı & $\mathbf{1}$ & $\mathbf{2}$ & $\mathbf{3}$ & $\mathbf{4}$ & $\mathbf{5}$ & $\mathbf{6}$ & $\mathbf{7}$ & $\mathbf{8}$ & $\begin{array}{l}\mathbf{1} \\
\mathbf{0}\end{array}$ & $\begin{array}{l}\text { Cevapsi } \\
\mathbf{z}\end{array}$ \\
\hline Afganistan & 1 & 3 & 4 & 1 & 1 & 1 & & 1 & 1 & 3 \\
& 3 & 0 & 9 & 5 & 4 & & & & & \\
\hline Irak & 4 & 2 & 1 & 2 & 2 & & & & 26 \\
& 0 & 7 & 5 & & & & & & \\
\hline İran & 9 & 1 & 1 & 5 & 6 & & 2 & & 20 \\
\hline Misır & 6 & 8 & 6 & 1 & & & & & 7 \\
\hline Suriye & 2 & 5 & 1 & 9 & 1 & & 1 & & 2 \\
& 1 & & 2 & & & & & \\
\hline
\end{tabular}

Değiştirilen il sayısı ile diğer kriterler arasında yapılan çaprazlamalar sonucunda eğitim durumunun, evlilik durumunun, çocuk sayısının, cinsiyetin ve yaşın il değiştirme sayılarında dikkat çeken bir etkisinin olmadığı; aylık geliri yüksek olanların diğerlerine nispeten daha az il değiştirdikleri görülmektedir. Evli olan yabancıların da en az bekârlar kadar rahat il değiştirebildikleri görülmektedir.

İl değiştirmenin kendini Türkiye'de güvende hissetmek ile ilgili olup olmadığına bakıldığında 'Türkiye'de kendinizi güvende hissediyor musunuz?' sorusuna evet ve hayır diyenlerin de benzer sıklıkta il değiştirdikleri görülmektedir. Dolayısı ile yabancıların Türkiye'de il değiştirmesinin sebebi güvenlik vb. gibi nedenler olmayıp neredeyse tek nedeni ekonomiktir. Zaten tatmin edici gelir bulunursa ekonomik imkânların devam ettiği sürece gelir sağlanan yere yerleşildiği anlaşılmaktadır. Bu durumu aynı zamanda Türkiye'de kendini güvende hissetmeyenlerin bile farklı illerde hem de aileleri ile birlikte (en az 1 şehir değiştiren 309 kişinin evli ve dul olan 268 kişisi bu soruya; 253 evet, 15 hayır şeklinde cevap vermiştir) yeni başlangıçlar yapabilecek kadar güvende hissettikleri şeklinde yorumlamak mümkündür.

İl değiştirmediğini ifade eden 70 yabancının ülkelerine göre dağılımına bakıldığında şehirde sosyal ağlara sahip olan yabancıların diğerlerine göre daha az il değiştirdiği ya da direk şehre geldikleri görülmektedir.
Tablo 22: Başka Bir İlde Yaşamadan Doğrudan Yalova'ya Gelen Yabancıların Ülke Dağılımı Tablosu

\begin{tabular}{ccccc}
\hline Ülkesi & Afganistan & Amerika & Cezayir & Irak \\
\hline Kişi Sayısı & 3 & 1 & 1 & 24 \\
\hline İran & Mısır & Suriye & S.Arabistan & Toplam \\
\hline 20 & 7 & 2 & 12 & 70 \\
\hline
\end{tabular}

Yabancıların evlilik durumlarının ülke bazında değerlendirmesine bakıldığında; Rus ve tatarlar hariç tüm ülke kategorilerinde evli sayısı bekâr olanlardan bekârların sayısı da dul olanlardan fazladır. Ruslarda 2 evli 4 bekâr 7 dul bulunmaktadır. Tatarlarda ise 2 evli 4 bekâr 3 dul bulunmaktadır. Rus ve Tatarların hem dil olarak hem de sayı olarak azınlıkta olmaları hem kendi kültürlerine yakın kişiler ile tanışma olasılıklarını düşürdüğü hem de gurbette yerli veya diğer bir yabancı ile evlenebilmeyi kolaylaştıran toplumsal güven duygusunun önünde bir engel oluşturduğu anlaşılmaktadır.

Tablo 23: Başlıca Kaynak Ülkelerin Evlilik Durumları

\begin{tabular}{|c|c|c|c|c|c|c|c|}
\hline & Afganistan & Irak & Iran & Misır & Suriye & $\begin{array}{c}\text { S. } \\
\text { Arabistan }\end{array}$ & Rusya \\
\hline Bekâr & 39 & 39 & 27 & 6 & 10 & 6 & 4 \\
\hline Dul & 11 & 9 & 2 & & 7 & 2 & 7 \\
\hline Evli & 77 & 63 & 35 & 22 & 34 & 15 & 2 \\
\hline
\end{tabular}

Bunun yanında 43 duldan 42'si kadınken sadece biri erkektir. Yabancı erkeklerin dul kalmadıkları ya da (çocuklara bakım vb. nedenlerle) kalamadıkları anlaşılmaktadır. Dul olan 42 kadının 31 'inin işsiz olduğu, ülkelerinin Afganistan (10 kadın), Irak (9 kadın), Rusya 7 kadın), Suriye (7 kadın), Tataristan(3 kadın), Eritre (2 kadın), S. Arabistan (2 kadın) görülmektedir. Türkiye'de kendinizi güvende hissediyor musunuz sorusuna dul kadınların 39'u evet, 3'ü hayır demiştir. 29 dul kadın suç mağduru olmaktan korkmadıklarını, 5'i (Rusya 3, Irak 1, Afgan 1) sığınmacılardan tedirginlik duyduklarını, 8'i (Irak 2, Rusya 2, Suriye 2, Afgan 1, Tatar 1) ülke vatandaşlarından tedirginlik duyduklarını ifade etmişlerdir. Suç mağduru olmaktan korkan 13 kadının yaşları ise 25-66 yaş aralığındadır.

Aylık gelirin az olması ile bekârlık arasında bir doğru orantı olduğu, alt gelir grubunda evlilik ve dul kalma oranlarının daha fazla olduğu, üst gelir grubunda dul kalma oranların daha az olduğu dikkat çekmektedir.

Tablo 24: Aylık Gelire Göre Evlilik Durumu

\begin{tabular}{lccccc}
\hline & Bekâr & Dul & Evli & Cevapsız & Toplam \\
\hline $\mathbf{0 - 1 5 0 0}$ & 74 & 23 & 110 & & 207 \\
\hline $\mathbf{1 5 0 0 - 3 0 0 0}$ & 53 & 17 & 75 & 1 & 146 \\
\hline 3000 ve üzeri & 12 & 3 & 81 & 1 & 97 \\
\hline Toplam & 139 & 43 & 266 & 2 & 450 \\
\hline
\end{tabular}

Çocuk sayısının eğitim düzeyi ile anlamlı bir farklılık göstermediği görülmüştür. Mesela okulsuz, ilk, lisans ve lisansüstü eğitim almış olanların birer kişisinde 9 çocuk sahipliği bulunmaktadır. Fakat ilginç bir şekilde aylık gelirin düşük olması ile çocuk sayılarının fazla olması veya aylık gelirin çok olması ile çocuk sayısının az olması arasında bir orantı olduğu görülmektedir. 
Tablo 25: Aylık Gelire Göre Çocuk Sayısı Durumu

\begin{tabular}{lllllllllllll}
\hline & $\mathbf{1}$ & $\mathbf{2}$ & $\mathbf{3}$ & $\mathbf{4}$ & $\mathbf{5}$ & $\mathbf{6}$ & $\mathbf{7}$ & $\mathbf{8}$ & $\mathbf{9}$ & $\mathbf{1 0}$ & $\mathbf{1 1}$ & $\mathbf{1 2}$ \\
\hline $\mathbf{0 - 1 5 0 0}$ & 12 & 26 & 27 & 16 & 13 & 8 & 3 & 8 & 4 & 3 & 1 & 2 \\
\hline $\mathbf{1 5 0 0 - 3 0 0 0}$ & 14 & 34 & 16 & 13 & 6 & 2 & & 2 & & & & \\
\hline $\begin{array}{l}\text { 3000 } \\
\text { üzeri }\end{array}$ & ve & 8 & 29 & 20 & 8 & 11 & 6 & 1 & & & & \\
\hline
\end{tabular}

Ülkelere göre çocuk sahipliği sayılarına bakıldığında ise sıra ile Afganistan, Irak ve Suriye'den gelenlerin diğer ülkelere nazaran daha çok çocuk sahibi oldukları görülmektedir.

\section{Tablo 26: Ülkelere Göre Çocuk Sahipliği}

\begin{tabular}{|c|c|c|c|c|c|c|c|c|c|c|c|c|c|}
\hline Cocuk Sayisı & $\mathbf{1}$ & $\mathbf{2}$ & $\mathbf{3}$ & $\mathbf{4}$ & $\mathbf{5}$ & $\mathbf{6}$ & $\mathbf{7}$ & $\mathbf{8}$ & $\mathbf{9}$ & $\mathbf{1 0}$ & $\mathbf{1 1}$ & $\mathbf{1 2}$ & Toplam \\
\hline Afganistan & 7 & 16 & 14 & 11 & 10 & 5 & 2 & 9 & 4 & 3 & 1 & 2 & 84 \\
\hline Afrikalı & & 1 & 1 & & & & & & & & & & 2 \\
\hline Azerbaycan & & 1 & & & & & & & & & & & 1 \\
\hline Cezayir & & 1 & 1 & & & & & & & & & & 2 \\
\hline Eritre & & & 2 & & & & & & & & & & 2 \\
\hline Filistin & 1 & & 1 & & & & & & & & & & 2 \\
\hline Irak & 5 & 23 & 19 & 7 & 11 & 5 & 1 & 1 & & & & & 72 \\
\hline Iran & 14 & 11 & 5 & 2 & 1 & & & & & & & & 33 \\
\hline Kurgizistan & & 1 & & & & & & & & & & & 1 \\
\hline Kuveyt & & & & & & 1 & & & & & & & 1 \\
\hline Misir & 2 & 7 & 4 & 4 & 1 & 3 & & & & & & & 21 \\
\hline Pakistan & & & & 1 & & & & & & & & & 1 \\
\hline Rusya & & 6 & 1 & & 1 & & & & & & & & 8 \\
\hline Sudan & & 1 & & & & & & & & & & & 1 \\
\hline Suriye & 2 & 9 & 7 & 10 & 6 & 2 & 1 & & & & & & 37 \\
\hline S.Arabistan & 1 & 9 & 7 & & & & & & & & & & 17 \\
\hline Tataristan & & 3 & 1 & 1 & & & & & & & & & 5 \\
\hline Ukrayna & 2 & & & & & & & & & & & & 2 \\
\hline Ürdun & & & & 1 & & & & & & & & & 1 \\
\hline Toplam & 34 & 89 & 63 & 37 & 30 & 16 & 4 & 10 & 4 & 3 & 1 & 2 & 293 \\
\hline
\end{tabular}

Özellikle Afganların çok çocuk sahibi olmaları farklı bir durumu ifade etmektedir. Çünkü mevcut literatürde Türkiye'ye Asya'dan gelen göçmenlerin genellikle zorlu coğrafya koşullarını aşmak için fiziksel olarak yeterlilik sahibi olan, ekonomik motivasyonlu, bireysel ve transit göçmenler olduğu düşünülmektedir. Görüşme gerçekleştirilen 127 Afgan'in 77'si evli, 11'i dul, 39'unun bekâr olduğu, bekâr olan Afganların 15-30 yaş aralığında olduğu görülmektedir. Çalışmadaki verilerin çaprazlanmasından Asya kaynaklı bir göç olarak Afgan göçünün nitelik değiştirdiği Suriye, Irak vb. Arap yoğun göçlere benzer şekilde aileleşen ve hedef ülkeye yerleşilen bir duruma evirildiği anlaşılmaktadır.Anket sırasında görüşülen Afganların, İranlıların, Tataristanlıların vb. beyanından, uzun süreden beri devam edegelen Asya'dan göçün artık bir anlamda 'gayri resmi olarak kurumsallaştığı', göç için bilinmesi gereken ne zaman, nerede, kimlerle, nasıl soruların cevabını rahatlıkla buldukları, göçten önce teorik olarak üzerinden geçebildikleri bir 'göç güzergâh kültürü' yaratıldığı anlaşılmaktadır. Bu durum göçün en temel unsuru olan 'bilinmeze yolculuk' niteliğini yumuşatmakta ve göçü teşvik edici bir rol oynamaktadır.Görüşülen bazı kişiler, defalarca nasıl deport edildiklerini ve nasıl yeniden Türkiye'ye girdiklerini, kimi zaman birkaç kere kendilerini aynı resmi görevlilerin deport işlemi yaptıklarını rahatlıkla ifade etmişlerdir.
Son olarak örneklemin adli birimlere gitme durumlarının ülkelere göre dağılımına baktığımızda bir şekilde adli birimler ile temas etmiş olan 87 kişinden her kategorideki ilk üç ülke sıralamasına baktığımızda: Müşteki olarak; Irak, Suriye, Mısır; Şüpheli olarak; Irak Suriye Afganistan/İran; Tanık Olarak; Irak Afganistan ve İran/Suriye olduğu görülmektedir.Sayı olarak Afganların fazla olmasına karşın müşteki ve Şüpheli olma noktasında 1rak, mısır ve Suriyelilerin arkasında kaldıkları, tanık olarak ise Iraklıların arkasında kaldıkları görülmektedir. Bu durum yukarıdaki örneklem analizi ile örtüşmektedir. Şöyle ki Afganların merkezde değil çevrede oturdukları, işveren değil iş̧̧i oldukları, kamusal alanda değil kendi özel alanlarında sosyalleştikleri göz önüne alındığında Afganların müşteki ve şüpheli olarak adli birimlere Arapça konuşanlardan daha az gelmeleri şaşırtıcı olmayacaktır. Yapılan görüşmelerde Afganların tanıklıklarının patronları için ya da olayda şüpheli olarak yakalanmış ama olay anlaşıldıktan sonra hukuki statüsü değiştiği için tanık oldukları, bir anlamda mecburi tanık oldukları anlaşılmıştır. Arapça konuşanlarda da benzer bir mecburiyetten bahsedilebilse bile Arapça konuşanların birbirleri için tanıklık yapma noktasında daha gönüllü ve çekincesiz oldukları görülmüştür.

Tablo 27: Ülkelere Göre Adli Birimler Gitme Dağılımları

\begin{tabular}{|c|c|c|c|c|c|c|c|c|c|}
\hline \multicolumn{4}{|c|}{ Gitmedim } & \multicolumn{2}{|c|}{ Müşteki Olarak } & \multicolumn{2}{|c|}{ Şüpheli Olarak } & \multicolumn{2}{|c|}{ Tanık Olarak } \\
\hline Toplam & 363 & Eritre & 4 & Toplam & 42 & Toplam & 19 & Toplam & 26 \\
\hline Afganistan & 113 & Cezayir & 3 & Irak & 11 & Irak & 8 & Irak & 11 \\
\hline Irak & 82 & Filistin & 2 & Suriye & 9 & Suriye & 6 & Afganistar & 7 \\
\hline İran & 58 & Ukrayna & 2 & Misır & 8 & Afganistar & 2 & İran & 2 \\
\hline Suriye & 34 & Ürdün & 2 & S. Arabistan & 4 & İran & 2 & Suriye & 2 \\
\hline Misir & 19 & Afrikalı & 1 & Afganistan & 5 & Kirgizistal & 1 & Afrikalı & 1 \\
\hline S. Arabistan & 18 & Amerika & 1 & İran & 3 & & & Misir & 1 \\
\hline Rusya & 13 & Kirgzistan & 1 & Azerbaycan & 1 & & & Sudan & 1 \\
\hline Tataristan & 8 & Kuveyt & 1 & Tataristan & 1 & & & rabistan & 1 \\
\hline & & Pakistan & 1 & & & & & & \\
\hline
\end{tabular}

Adli birimlere gitme durumlarının cinsiyete ve yaşa göre dağılımlarına bakıldığında ise erkeklerin kadınlara göre müşteki, şüpheli ve tanık olma durumlarının daha fazla olduğu görülmektedir. Buna karşın sadece müşteki ve tanık olmak bakımından erkek ve kadın arasındaki oranlar oldukça yakındır. Sadece şüpheli olma durumunda erkeklerin kadınlara göre daha önde oldukları görülmektedir. Dolayısı ile kadınların adli birimlere müracaat etme noktasında tedirginlik duymadıkları anlaşılmaktadır. 26-45 yaş arasında olanların daha fazla Adli birimlerle temas kurduğu görülmektedir. 
Tablo 28: Yaş ve Cinsiyete Göre Adli Birilere Gitme Dağılımları

\begin{tabular}{|c|c|c|c|c|c|}
\hline & Gitmedim & $\begin{array}{c}\text { Müșteki } \\
\text { Olarak }\end{array}$ & $\begin{array}{c}\text { Şüpheli } \\
\text { Olarak }\end{array}$ & $\begin{array}{c}\text { Tanık } \\
\text { Olarak }\end{array}$ & Toplam \\
\hline $\mathbf{1 6 - 2 5}$ & 99 & 3 & 3 & 4 & 109 \\
\hline $\mathbf{2 6 - 3 5}$ & 114 & 19 & 8 & 7 & 148 \\
\hline $\mathbf{3 6 - 4 5}$ & 74 & 14 & 3 & 9 & 100 \\
\hline $\mathbf{4 6 - 5 5}$ & 46 & 3 & 3 & 3 & 55 \\
\hline $\mathbf{5 6 +}$ & 30 & 3 & 2 & 3 & 38 \\
\hline Toplam & 363 & 42 & 19 & 26 & 450 \\
\hline Erkek & 146 & 23 & 13 & 15 & 197 \\
\hline Kadın & 217 & 19 & 5 & 11 & 252 \\
\hline Trans & & & 1 & & 1 \\
\hline Toplam & 363 & 42 & 19 & 26 & 450 \\
\hline
\end{tabular}

Aylık gelir grubuna göre adli birimlere gitme dağılımlarına bakıldığında ise alt gelir grubunda tanık olma durumunun, orta ve üst gelir grubunda müşteki olma durumunun, orta gelir grubunda ise şüpheli olma durumunun fazla olduğu görülmektedir.

Tablo 29: Aylık Gelir Grubuna Göre Adli Birimlere Gitme Dağılımları

\begin{tabular}{lcccc}
\hline & $\begin{array}{l}\mathbf{0 -} \\
\mathbf{1 5 0 0}\end{array}$ & $\begin{array}{c}\mathbf{1 5 0 0 -} \\
\mathbf{3 0 0 0}\end{array}$ & $\mathbf{3 0 0 0 +}$ & Toplam \\
\hline Gitmedim & 179 & 113 & 71 & 363 \\
\hline Müş̧teki Olarak & 8 & 18 & 16 & 42 \\
\hline Şüpheli Olarak & 5 & 10 & 4 & 19 \\
\hline Tanık Olarak & 15 & 5 & 6 & 26 \\
\hline Toplam & 207 & 146 & 97 & 450 \\
\hline
\end{tabular}

Türkiye'de kalma süreleri ile adli birimlere gitme dağılımları arasındaki ilişkiye bakıldığında, kalma süresinin artması ile adli birimlere gitme durumunun doğru orantılı olduğu görülmektedir.

Tablo 30: Türkiye'de Kalma Sürelerine Göre Adli Birimlere Gitme Dağılımları

\begin{tabular}{lccccc}
\hline & $\begin{array}{l}\text { 1 Gün - } \\
\text { 1 Yıl }\end{array}$ & $\begin{array}{l}\mathbf{2 - 3} \\
\text { Yıl }\end{array}$ & $\begin{array}{l}\mathbf{4 - 5} \\
\text { Yıl }\end{array}$ & $\begin{array}{l}\text { 6 } \\
\text { ve }+\end{array}$ & Toplam \\
\hline Gitmedim & 134 & 153 & 60 & 16 & 363 \\
\hline Müşteki Olarak & 5 & 9 & 20 & 8 & 42 \\
\hline Şüpheli Olarak & 2 & 7 & 5 & 5 & 19 \\
\hline Tanık Olarak & 2 & 13 & 9 & 2 & 26 \\
\hline Toplam & 143 & 182 & 94 & 31 & 450 \\
\hline
\end{tabular}

Türkçeye hâkimiyete göre adli birimlere gitme dağılımlarına baktığımızda şüpheli ve tanık olanların Türkçe okuma ve yazma bağlamında Türkçeye hâkimiyetin oldukça zayıf olduğu fakat anlama ve konuşma seviyelerinin daha iyi olduğu görülmektedir. Müştekilerin Türkçe hâkimiyetlerinin ise tüm kategorilerde ortalama/vasat olduğu görülmektedir. Görüldüğü gibi şüphelilerin Türkçeye hâkimiyetleri müştekilere göre daha fazladır. İlk bakışta bu durum şaşırtıcı gelebilir. Çünkü ülke vatandaşları için genellikle eğitim durumu ve suç işleme davranışı arasında veya eğitim durumu ve müşteki olma arasında doğru orantı olduğu düşünülür. Fakat yabancılar için, ekonomik durum ve eğitim seviyesinin doğru orantılı olmadığı verisi açısından değerlendirildiğinde, bu durum örneklem verilerinin analizi ile örtüşmektedir.

Tablo 31: Türkçeye Hâkimiyete Göre Adli Birimlere Gitme Dağılımları

\begin{tabular}{|l|c|c|c|c|c|c|c|c|c|}
\hline & \multicolumn{4}{|c|}{ Az-0rta } & \multicolumn{4}{|c|}{ İyi-Cok Iyj } & \multirow{2}{*}{ Kiși Sayısı } \\
\cline { 2 - 11 } & 0kuma & Yazma & Anlama & Konuşma & 0kuma & Yazma & Anlama & Konuşma & \\
\hline Süpheli & 14 & 14 & 5 & 5 & 5 & 5 & 14 & 14 & 19 \\
\hline Müșteki & 22 & 22 & 14 & 14 & 20 & 20 & 28 & 28 & 42 \\
\hline Tanık & 20 & 20 & 12 & 12 & 6 & 6 & 14 & 14 & 26 \\
\hline
\end{tabular}

Eğitim durumlarına göre adli birimlere gitme dağılımlarına bakıldığında ise müştekilerin genelinin orta ve lisans, şüphelilerin genel olarak ilk ve orta, tanıkların ise ilk, orta ve lisans mezunu oldukları görülmektedir. Fakat özellikle lisans mezuniyeti ile birlikte şüpheli olma durumunda net bir düşüş olduğu görülmektedir.

Tablo 32: Eğitim Durumlarına Göre Adli Birimlere Gitme Dağılımları

\begin{tabular}{lcccccc}
\hline & Yok & İlk & Orta & Lisans & $\begin{array}{l}\text { Lisans } \\
\text { Üstü }\end{array}$ & Toplam \\
\hline Gitmedim & 40 & 59 & 122 & 108 & 34 & 363 \\
\hline $\begin{array}{l}\text { Müşteki } \\
\text { Olarak }\end{array}$ & 2 & 7 & 11 & 18 & 4 & 42 \\
\hline Şüpheli Olarak & 2 & 6 & 9 & 1 & 1 & 19 \\
\hline Tanık Olarak & 2 & 6 & 9 & 8 & 1 & 26 \\
\hline Toplam & 46 & 78 & 151 & 135 & 40 & 450 \\
\hline
\end{tabular}

Yabanciların Kurumsal Adalet

Algisının

Değerlendirilmesi:

Adli Birimlerde Kendilerini İfade Edebilme Ĕ̆ilimlerinin Değerlendirilmesi:Adli birimler ile kişisel bir deneyim yaşamış (müşteki, tanık, şüpheli) olan yabancıların (87 kişinin) \% 89,65'i, gitmemiş olan yabancıların (363 kişinin) $\% 76,58$ 'i kendini adli birimlerde ifade edebileceğine inantyorken; adli birimlere gidenlerin \% 10,34'üvegitmeyenlerin \%23,14'ü adli birimlerde kendilerini doğru bir biçimde ifade edemeyeceklerine inanmaktadırlar. Kendini ifade etme oranlarının adli birimlere gidenlerde gitmeyenlere göre daha fazla çıkması adli birimlere giden yabancıların kendilerini ifade etmek noktasında olumlu deneyim yaşadıklarını göstermektedir.

Adli birimlerde kendini ifade edemeyeceğine inanların (92 kişinin) ülke dağılımlarına (1 Amerikalı hariç) bakıldığında sıralamanın; Afganistan, İran, Rusya, Tataristan, Irak, Suriye, Misır, S.Arabistan, Eritre ve Filistin olduğu görülmektedir. 
Tablo 33: Kendini Adli Birimlerde İfade Edebilme İnancının Ülkelere Göre Dağılımı

\begin{tabular}{|c|c|c|c|c|c|c|}
\hline \multicolumn{2}{|c|}{$\begin{array}{ll}\text { Kendini } & \text { İfade } \\
\text { Edebilme İnancı } & \\
\end{array}$} & \multirow{2}{*}{\begin{tabular}{|c|} 
Afganistan \\
119 \\
\end{tabular}} & \multirow{2}{*}{\begin{tabular}{|r} 
Eritre \\
2
\end{tabular}} & \multirow{2}{*}{$\begin{array}{r}\text { Filistin } \\
1 \\
\end{array}$} & \multirow{2}{*}{\begin{tabular}{|r} 
Irak \\
83 \\
\end{tabular}} & \multirow{2}{*}{$\begin{array}{r}\text { İran } \\
52\end{array}$} \\
\hline & Sayı & & & & & \\
\hline & $\%$ & 93,7 & 50 & 50 & 74,1 & 80 \\
\hline \multirow{2}{*}{ Hayır } & Sayı & 8 & 2 & 1 & 29 & 13 \\
\hline & $\%$ & 6,29 & 50 & 50 & 25,89 & 20 \\
\hline \multicolumn{2}{|c|}{ Toplam } & 127 & 4 & 2 & 112 & 65 \\
\hline \multicolumn{2}{|c|}{$\begin{array}{ll}\text { Kendini İfade } \\
\text { Edebilme İnancs }\end{array}$} & Misir & Rusya & Suriye & $\begin{array}{l}\text { S. } \\
\text { Arabistan } \\
\end{array}$ & Tataristan \\
\hline \multirow{2}{*}{ Evet } & Sayı & 19 & 10 & 36 & 12 & 7 \\
\hline & $\%$ & 67,85 & 76,92 & 72 & 52,17 & 77,77 \\
\hline \multirow{2}{*}{ Hayır } & Sayı & 9 & 3 & 14 & 11 & 2 \\
\hline & $\%$ & 32,14 & 23,07 & 28 & 47,82 & 22,22 \\
\hline \multicolumn{2}{|c|}{ Toplam } & 28 & 13 & 50 & 23 & 9 \\
\hline
\end{tabular}

Farsça konuşanların Arapça konuşanlara göre adli birimlerde kendilerini daha iyi ifade edebileceklerini inandıkları görülmektedir.

Kendini adli birimlerde ifade edebilme inancının yaş ve cinsiyet dağılımlarına bakıldığında ise 26-35 yaş aralığındaki kadın ve erkeklerde bu inancın en fazla olduğu, kadınlarda 36-45 yaş arasında olanlarda ve erkeklerde 4655 yaş arasında olanlarda bu inancın en az seviyede olduğu görülmektedir.

Tablo 34: Kendini adli birimlerde ifade edebilme inancının yaş ve cinsiyet dağılımları

\begin{tabular}{cccccccccccc}
\hline Yaş Aralığı & $\mathbf{1 5 - 2 5}$ & & $\mathbf{2 6 - 3 5}$ & $\mathbf{3 6 - 4 5}$ & $\mathbf{4 6 - 5 5}$ & $\mathbf{5 6}+$ \\
\hline $\begin{array}{c}\text { Kendini İfade } \\
\text { Edebilme İnancı }\end{array}$ & $\mathbf{E}$ & $\mathbf{K}$ & $\mathbf{E}$ & $\mathbf{K}$ & $\mathbf{E}$ & $\mathbf{K}$ & $\mathbf{E}$ & $\mathbf{K}$ & $\mathbf{E}$ & $\mathbf{K}$ \\
\hline \multirow{2}{*}{ Evet } & Sayı & 41 & 41 & 50 & 77 & 33 & 40 & 21 & 22 & 15 & 15 \\
\cline { 2 - 11 } & $\mathbf{\%}$ & 75 & 76 & 91 & 85 & 79 & 69 & 88 & 71 & 75 & 83 \\
\hline \multirow{2}{*}{ Hayır } & Sayı & 14 & 13 & 5 & 14 & 9 & 18 & 3 & 9 & 5 & 3 \\
\hline & $\mathbf{\%}$ & 25 & 24 & 9,1 & 15 & 21 & 31 & 13 & 29 & 25 & 17 \\
\hline Toplam & 55 & 54 & 55 & 91 & 42 & 58 & 24 & 31 & 20 & 18 \\
\hline
\end{tabular}

Not: kendini ifade edebileceğine inanan 34 yaşındaki trans tabloda değildir.

Kendini adli birimlerde ifade edebilme inancının Türkçeye hâkimiyete dağılım oranlarına bakıldığında ise; Türkçe okuryazarlığın iyi veya çok iyi olması ile adli birimlerde kendini ifade edebilme inancı arasında doğru orantı olduğu görülmektedir.
Tablo 35: Kendini Adli Birimlerde İfade Edebilme İnancının Türkçeye Hâkimiyete Göre Dağılımı

\begin{tabular}{|c|c|c|c|c|c|}
\hline \multicolumn{2}{|c|}{ Türkçeye Hâkimiyet } & \multicolumn{4}{|c|}{ Az-Orta } \\
\hline $\begin{array}{c}\text { Kendini İfade } \\
\text { Edebilme İnancı }\end{array}$ & Okuma & Yazma & Anlama & Konuşma \\
\hline \multirow{2}{*}{ Evet } & S ayı & 262 & 262 & 175 & 178 \\
\cline { 2 - 6 } & $\%$ & 76,2 & 75,9 & 72,6 & 72,7 \\
\hline \multirow{2}{*}{ Hayır } & S ayı & 82 & 83 & 66 & 67 \\
\cline { 2 - 6 } & \% & 23,8 & 24,1 & 27,4 & 27,3 \\
\hline \multicolumn{2}{|c|}{ Toplam } & 344 & 345 & 241 & 245 \\
\hline Türkçeye Hâkimiyet & & \multicolumn{4}{|c|}{ İyi- Çok İyi } \\
\hline \multirow{2}{*}{$\begin{array}{c}\text { Kendini İfade } \\
\text { Edebilme İnancı }\end{array}$} & Okuma & Yazma & Anlama & Konuşma \\
\hline \multirow{2}{*}{ Evet } & S ayı & 94 & 94 & 179 & 178 \\
\cline { 2 - 6 } & $\%$ & 90,4 & 90,4 & 86,9 & 87,3 \\
\hline \multirow{2}{*}{ Hayır } & S ayı & 10 & 10 & 27 & 26 \\
\cline { 2 - 6 } & $\% \%$ & 9,61 & 9,61 & 13,1 & 12,7 \\
\hline \multicolumn{2}{|c|}{ Toplam } & 104 & 104 & 206 & 204 \\
\hline \multicolumn{2}{|c|}{ Genel Toplam } & 448 & 449 & 447 & 449 \\
\hline
\end{tabular}

Adli Birimlere Müracaat Etme Eğilimlerinin Dĕgerlendirilmesi:Adli birimlerde kendini ifade etme konusunda yabanciların kendilerine duydukları güven ile adli birimlere müracaat etme kararını verme süreçlerinin birbirini etkilemediği görülmektedir. Adli birimlere müracaat etme kararını kendi verenler (188 kişi)içinde adli birimlerde kendilerini ifade edeceğine inanlar \%82,44 iken; yakınlarında danışarak karar verenler (262 kişi) içinde bu oran $\% 76,71$ 'dir.

Amerika, Cezayir, Filistin, İran haricindeki ülkelerde adli birimlere müracaat ederken yakınlara danışma eğiliminin daha yüksek olduğu; yakınlara danışma eğilimi olan ülkelerin başında Rusların (\%76,92'si), Suriyelilerin (\%70,58'i)ve Afganistanlıların (\%64,56’sı) geldiği görülmektedir.

Kadınların ise erkeklere göre yakınlara danışma eğilimleri daha yüksektir. Örneklem bazında erkeklerin \%37,05, kadınların ise $\% 75$ 'i yakınlarına danışmadan adli birimlere müracaat etmeyeceğini ifade etmektedir.

Örneklem bazında yakınlara danışma ve yaş grupları arasındaki ilişkiye baktığımızda ise; $15-25$ yaş arasının $\% 64,22,26-35$ yaş arasının \%53,37, 36-45 yaş arasının $\% 56,46-55$ yaş arasının \%67,27, $56+$ yaşın \%52,6 ile yakınlara danışma eğilimi taşıdıkları görülmektedir. Görüldüğ̈ gibi yabancılar adli birimlere müracaat ederken 35 yaşına kadar görece daha fevri olma eğiliminde 35-56 yaş arası yüksek bir oranla yakınlarına danışma eğiliminde fakat 56 yaş sonrasında yine fevri kararlar verme eğilimindedirler.

Yakınlara danışma ve gelir grubu ilişkisine baktığımızda gelirin yükseldikçe yakınlara danışma eğiliminin azaldığı görülmektedir. Alt gelir gurubunun $\% 63$, orta gelir grubunun $\% 55$, üst gelir grubunun ise \%50'sinin yakınlarına danışarak adli birimlere müracaat ettikleri anlaşılmaktadır.

Bekârların \%53,23'ünün, dulların \%72,09'unun, evlilerin ise \%59.02'sinin yakınlarına danışarak adli birimlere müracaat ettikleri dolayısı ile evlilik durumunun müracaat ederken yakınlara danışmayı fazla etkilemediği anlaşılmaktadır. 
Kendini adli birimlerde ifade edebilme inancının Türkiye'de bulunma süresine dağılımlarına bakıldığında bulunma süresi arttıkça adli birimlerde kendini ifade etmeye duyulan inancın arttığ fakat bu inancın 6 ve üzeri yıl Türkiye'de bulunan yabancılarda ilginç bir biçimde düşüş gösterdiği anlaşılmaktadır. 6 ve üzeri yıl Türkiye'de bulunan ve kendilerini adli birimlerde rahat ifade edemeyeceklerine inanan 8 kişiye daha yakından baktığımızda; bu kişilerin; 20-60 yaş arası oldukları, hiç adli birimlere temas etmedikleri, hepsinin kendilerini Türkiye'de güvende hissettikleri, sadece 3'ünün ülke vatandaşlarından gelebilecek bir suç korkusu yaşadıkları, 6'sının firsatı olması halinde Türkiye'de kalmak istediği, ülkelerinin Suriye (5), Irak (2), Afganistan (1) olduğu, gelir dağglımlarının (4) alt, (2) orta, (2) üst gelir grubundan olduğu görülmektedir. Dolayısı ile 6 yılın üzerinde süre Türkiye'de kalan kişilerdeki adli birimlerde kendilerini ifade etmek noktasında azalan inancın anlaşılır bir nedeni bulunamamıştır.

Tablo 36: Kendini Adli Birimlerde İfade Edebileceğine İnananların Türkiye'de Bulunma Süreleri Dağılımı

\begin{tabular}{|c|c|c|c|c|c|}
\hline \multicolumn{2}{|c|}{$\begin{array}{l}\text { Türkiye'de } \\
\text { bulunma süresi }\end{array}$} & \multirow{2}{*}{$\begin{array}{l}1 \\
\text { gün } \\
1 \text { yıl }\end{array}$} & \multirow{2}{*}{$\begin{array}{l}2-3 \\
\text { yll }\end{array}$} & \multirow{2}{*}{$\begin{array}{l}4-5 \\
\text { yll }\end{array}$} & \multirow{2}{*}{$\begin{array}{l}6 \text { yil } \\
\text { ve + }\end{array}$} \\
\hline $\begin{array}{l}\text { Kendini } \\
\text { Edebilm }\end{array}$ & $\begin{array}{l}\text { İfade } \\
\text { lancı }\end{array}$ & & & & \\
\hline \multirow{2}{*}{ Evet } & Sayı & 101 & 153 & 79 & 23 \\
\hline & $\%$ & 70,62 & 84,06 & 84,04 & 74,19 \\
\hline \multirow{2}{*}{ Hayır } & Sayı & 41 & 29 & 15 & 8 \\
\hline & $\%$ & 28,67 & 15,93 & 15,95 & 25,8 \\
\hline
\end{tabular}

Adli birimlerde kendini ifade edebileceğini beyan edenlerin (356 kişinin) \%39'u yabancı birinin bir Türk ile sorun yaşaması halinde adli birimlere müracaat edeceğini düşünürken; \%19,94'ü bir Türk ile sorun yaşanması halinde adli birimlere müracaat etmeyeceğini; $\% 40,44$ ise sadece önemli olaylarda adli birimlere müracaat edeceğini düşünmektedir. İlginç bir şekilde bu oranlar kendini adli birimlerde ifade edemeyeceğine inananlarda (93 kişidir) daha fazladır. Şöyle ki bu kişilerin (93 kişinin) \% 48,38'i bir Türk ile sorun yaşaması halinde yabancıların adli birimlere gideceğini, \%17,2'si gitmeyeceğini, \% 34,4’ü önemli olaylarda gideceğini ifade etmektedir.

Adli birimlerde kendini ifade edebileceğini beyan edenlerin (356 kişinin) yabancıların kendi aralarındaki sorunlar için adli birimlere müracaatları konusunda; \%33,14 gideceklerini, \%25 gitmeyeceklerini, $\% 41,85$ ise sadece önemli olaylarda gideceklerini düşünmektedir. Kendini adli birimlerde ifade edemeyeceğine inananların (93 kişinin) ise; \%41,93 gider, \%20,43 gitmez, \%37,63 önemli olaylarda gider cevabını verdiği görülmektedir.

Tablo 37: Kendini Adli Birimlerde İfade Edebileceğine İnanların Adli Birimlere Müracaat Eğilimleri

\begin{tabular}{cccccc}
\hline $\begin{array}{c}\text { Uyuşmazlık } \\
\text { Yaşananın } \\
\text { Uyruğu }\end{array}$ & $\begin{array}{c}\text { Kişi } \\
\text { Sayısı }\end{array}$ & $\begin{array}{c}\text { Kendini } \\
\text { İfade } \\
\text { Etme } \\
\text { İnancı }\end{array}$ & Gider & Gitmez & $\begin{array}{c}\text { Önemli } \\
\text { Olaylarda } \\
\text { Gider }\end{array}$ \\
\hline Türk & 356 & Evet & $\% 39$ & $\% 19,94$ & $\% 40,44$ \\
\cline { 2 - 6 } & 93 & Hayır & $\% 48,38$ & $\% 17,2$ & $\% 34,4$ \\
\hline Yabancı & 356 & Evet & $\% 33,14$ & $\% 25$ & $\% 41,85$ \\
\cline { 2 - 6 } & 93 & Hayır & $\% 41,93$ & $\% 20,43$ & $\% 37,63$ \\
\hline
\end{tabular}

Yabancıların, az bir farkla, yabancılarla uyuşmazlık yaşamaları halinde adli birimlere gitmeye daha fazla eğilimli oldukları anlaşılmaktadır. Ayrıca kendini ifade edemeyeceğine inanan yabancıların gerek Türk gerekse de yabancı ile uyuşmazlık yaşaması halinde adli birimlere gitme eğilimlerinin daha fazla olduğu görülmektedir. $\mathrm{Bu}$ durumda yabancıların kendini ifade edebilme inançlarından ve uyuşmazlık yaşadıkları kişinin uyruğundan bağımsız olarak adli birimlere güvendikleri anlaşılmaktadır.

Fakat tüm örneklem dikkate alındığında bir Türk ile uyuşmazlık yaşanması halinde \%19,33'ün gitmem; yabancı ile uyuşmazlık yaşanması halinde \%24'ünun gitmem demesi ve 'önemli olaylarda gider bile dememeleri', yaklaşık her 5 yabancıdan 1'inin uyuşmazlık yaşadıkları kişinin uyruğundan bağımsız olarak uyuşmazlık yaşadığı 'önemli olaylarda bile' hasmı olan kişi ile sorunun çözümü noktasında adli süreci bir alternatif olarak görmediğini ortaya koymaktadır.

Adli Sürece Güven Eğilimlerinin Değerlendirilmesi: Yabancıların \%70'i bir Türk ile uyuşmazlık yaşanması halinde Adli birimlerin kendilerine adil davranacağına inanmaktadır. Yabancıların kendi aralarındaki uyuşmazlıklarda adli birimlerin kendilerine adil davranacağına inanalar ise \%79'dur. Yani ortalama olarak her 4 yabancıdan 1'i uyruğuna bakılmaksızın bir uyuşmazlık konusu ile ilgili olarak adli birimlere gelmesi halinde kendisine adil davranılmayacağına inanmaktadır. Ayrıca yabancıların \%68'i, başka sığınmacıların gündemde olan suçlarından dolayı adli birimlerin kendisine olumsuz tavır almayacaklarına inanırken, \%32'si adli birimlerin kendisine karşı olumsuz tavır alacağına inanmaktadır

Bir Türk ile uyuşmazlık yaşanması halinde yabancıların adli birimlere gideceğini düşünen kişilerden (187 kişiden) adli sürecin adil olmadığına inanırsan nasıl davranırsın sorusuna, \%92.51'i bir üst mahkemeye başvururum derken \% 6,95'i cezasını kendisinin vereceğini; sadece önemli olaylarda gideceğini düşünen kişilerden (176 kişiden) \% 94,88'i bir üst mahkemeye giderim derken, \% 5,11'i cezasını kendinin vereceğini; adli birimlere gitmeyeceğini düşünenlerden (87 kişiden) \% 79,31'i bir üst mahkemeye giderim derken, \%20,68'i cezasını kendim veririm demektedir.

Yabancıların kendi aralarında uyuşmazlık yaşamaları halinde adli birimlere gideceğini düşünen kişilerden (158 kişiden) adli sürecin adil olmadığına inanırsan nasıl davranırsın sorusuna \%94,3'ü bir üst mahkemeye giderim derken \%9'u cezasını kendisinin vereceğini; sadece önemli olaylarda gideceğini düşünen kişilerden (184 kişiden) \%92,39'ü bir üst mahkemeye giderim derken \%7'si cezasını kendisinin vereceğini, adli birimlere gitmeyeceğini düşünenlerden \%90'1 bir üst mahkemeye giderim derken, $\% 16,66$ 's1 cezasının kendim veririm demektedir.

Yabancıların adli birimlere gitmeme eğilimlerinin arttıkça uyuşmazlık yaşanan kişinin (uyruğundan bağımsız olarak) cezasının kendileri tarafından verilmesi eğiliminin arttığ anlaşılmaktadır.

Bir Türk ile uyuşmazlık yaşadığında adli birimlerin kendisine adil davranacağını söyleyen kişilerden(316 kişiden) adli sürecin adil olmadığına inanması halinde, $\%$ 96,2'si bir üst mahkemeye temize gideceğini ifade ederken, \% 3,4'ü cezasını kendisinin vereceğini ifade etmiştir. Bu 
durum daha başlangıçta adli birimlerin kendisine adil davranmayacağına inanan (134 kişi) yabancılarda çok daha fazladır. Şöyle ki bu kişilerin (134 kişinin) \% 78'i bir üst mahkemeye başvuracağını ifade ederken, \% 21,64'ühasmının cezasını kendisinin vereceğini açıkça ifade etmektedir. Adli sürece karşı ön yargısı bulunan bir yabancının Türk ile yaşadığı uyuşmazlığa ilişkin adil davranılmadığını düşünmesi halinde ihkakı hak eğilimi 7 kat artmakta olduğu anlaşılmaktadır.

Yabancılar kendi aralarında uyuşmazlık yaşadığında adli birimlerin kendisine adil davranacağını düşünen kişiler (359 kişinin) adli sürecin adil olmadığına inanması halinde $\% 93,31$ 'i bir üst mahkemeye giderim derken $\% 6,4$ 'ü cezasını kendisinin vereceğini ifade etmiştir. $\mathrm{Bu}$ durum daha başlangıçta adli birimlerin kendisine adil davranmayacağına inanan (91 kişi) yabancılarda çok daha fazladır. Şöyle ki bu kişilerin (91 kişinin) \%81,31'i temize giderken, \%18,68'i cezasını kendisinin vereceğini ifade etmektedir. Adli sürece karşı ön yargısı bulunan bir yabancının başka bir yabancı ile yaşadığı uyuşmazlığa ilişkin adil davranılmadığını düşünmesi halinde ihkakı hak eğiliminin 3 kat artmakta olduğu anlaşılmaktadır.

Başka yabancıların işlediği suçlardan dolayı adli birimlerin kendisine olumsuz tavır almayacağına inanan kişilerden (306 kişinden), \%92,8'i adli birimlerin kendilerine adil davranmadığına inanması halinde bir üst mahkemeye gideceğini ifade ederken, $\% 7,1^{\prime} i$ cezasını kendisinin vereceğini söylemektedir. Yabancıların işlediği suçlardan dolayı adli birimlerin kendisine olumsuz tavır alacağına inanan kişilerden (144 kişiden) \%12,5 i cezasını kendisinin vereceğini, $\% 86,8$ ' $i$ ise bir üst mahkemeye müracaat edeceklerini söylemektedirler.Dolayısı ile başka yabancıların işlediği suçlardan sorumlu tutulma tedirginliğinin yabancıların ihkakı hak eğilimlerini arttırdığ görülmektedir.

Örneklemin\% 30,66's1 yabancılara karşı toplumsal bir tepki oluşması halinde devletin kendilerini koruyamayacağına inanmaktadır. Yine tüm örneklemin \%11,11'i hem başka sığınmacıları suçlarından dolayı adli birimlerin kendilerine karşı olumsuz bir tavır alacağına hem de toplumsal bir karmaşa durumunda devletin kendilerini koruyamayacağına inanmaktadır.

Yabancılara yönelik toplumsal bir tepkinin oluşması durumunda devletin kendisini koruyamayacağına inananların (138 kişinin) \%35'i Irak, \%14'ü Afganistan, $\% 13,76$ 's1 Suriye, \%12,31'i Misır, \%8,69'u İran menşelidir. $\mathrm{Bu}$ ülkeleri sırası ile S.Arabistan, Tataristan, Cezayir ve Rusya, Filistin, Azerbaycan takip etmektedir. Toplumsal bir tepki sırasında devletin kendisini koruyamayacağına inananların (138 kişinin) \%51 erkek, \%49'u kadın olup, \%29,71'i 26-35 yaş,\%25,36'si 36-45 yaş, \%23,71'i 15-25 yaş, \%13,76'su 46-55 yaş, \%7,97'si 56+ yaş grubundadır. Devletin kendisini koruyamayacağına inananlar arasında kadın erkek oranlarının birbirine yakınken,15-45 yaş arasında olan kişilerin devletin kendilerini koruyamayacağına ilişkin kanaatleri $46+$ yaş grubuna göre daha fazladır. Okulsuz olanların (46 kişinin) \%23,91'i, ilkokul mezunu (78 kişinin)olanların \%35,89'u, lisans mezunu (135 kişinin)olanların \%36,29’u, lisansüstü (40 kişinin) olanların \%17,5'i toplumsal bir tepki olması durumunda devletin kendilerini koruyamayacağına inanmaktadirlar.
Toplumsal bir olay olması durumunda devlete güvenmeyenlerin (138 kişinin) \%47,82'si, güvenenlerin (311 kişinin) \%33,44'ü suça karışan bir sığınmacının teslim olmayacağına inanmaktadır. Tüm örneklem (450 kişi) için bu oran \%37,77'dir. Toplumsal bir olay olmas1 durumunda devlete güvenmeyenlerde (138 kişide) kaçmak isteyen bir yabancının yakalanmayacağına duyulan inanç \%26 iken, güvenenlerde (311 kişide) bu oran \%25'dir. Dolayısı ile toplumsa bir olayda devlete güvenmeyenler ile güvenenlere göre yabancıların daha az bir oranda teslim olacağına inanmaktadırlar. Devlete hem güvenenlerde hem güvenmeyenlerde suça karışan bir yabancının adli birimlerce yakalanma ve yakalanamama oranları neredeyse aynıdır. Bu durum devlete güvenmeyenlerde bile suçluların yakalanabileceğine olan inancın güvenlerdekiler kadar olduğunu göstermesi bakımından önemlidir.

Fakat yine de örneklemde hâkim olan, suça karşılan 4 yabancıdan 1'inin yakalanamayacağı inancı yüksek bir orandır. Devlete güvenenlerin (311 kişinin) ihkakı hak (cezasını kendim veririm) eğilimleri \%4 iken, güvenmeyenlerde (138 kişide) bu oran \%18, 11 'dir. Devlete güven duymamanın ihkakı hak eğilimini 4,5 kat arttırdığı görülmektedir.

Toplumsal bir olayda devlete güvenenlerin \%29,9'u güvenmeyenlerin ise $\% 36,23$ 'ü başka yabancıların suçlarından dolayı adli birimlerin kendilerine olumsuz tavır alacağına; güvenenlerin $\% 17$ 'si, güvenmeyenlerin $\% 27$ 'si adli birimlerde kendisini ifade edemeyeceğine inanmaktadır. Yabancılar için toplumsal olaylarda devletin kendilerinin korunmasına ilişin vereceği güvenin daha doğrusu 'yaratacağı algının' onların adli birimlere müracaat, adli sürece güven ve ihkakı hak eğilimlerini doğrudan etkileyeceği anlaşılmaktadır.

Adli birimlerin adil davranmaması halinde cezasını kendisinin vereceğini söyleyen 40 kişiden 30'u 21-62 yaş arası erkeklerden, 10'unun ise 18-54 yaş arası kadınlardan oluştuğu görülmektedir. Erkeklerin 21'i 40 yaş altı, kadınların 8'i 40 yaşı altıdır. Dolayısı ile yaşadıkları uyuşmazlıklarda adil davranılmadığına inanması halinde, 40 yaş altı kadınlarda yabancılarda 40 yaş altı erkeklere göre ihkakı hak eğilimi daha fazla görünmektedir. Bu kişilerin (40 kişinin) ülke dağılımlarına bakıldığında ise \%45 Irak,\%27,5 Suriye, \%12,5 Afganistan, \%5 Misır, Rusya ve \%2,5 S.Arabistan menşei oldukları görülmektedir.

İlginç bir şekilde okulsuz olan 46 kişin hepsi bir üst mahkemeye giderek hakkımı ararım demiştir. İlkokul mezunlarından \%12,98', ortaokul mezunlarından \%15'i, lisans mezunlarından \%8,14'ü, lisansüstü mezunlarından \%10'u adil davranılmazsa cezasını kendilerinin vereceğini ifade etmişlerdir.

Aylık gelir baz alındığında ise alt gelir grubunun $\% 7,2$ 'sinin, orta gelir grubunun \%8,9'unun, üst gelir grubunun ise \%12,37 sinin ihkakı hak eğilimi taşıdığ görülmektedir. Ekonomik olarak kendine güvenen yabancıların ihkakı hakka daha eğilimli oldukları görülmektedir. Cezasını kendi verme eğiliminin evli ve bekârlarda $\% 9$ dullarda ise $\% 4$ oranında olduğu görülmektedir.

Adli birimlerin adil davranmaması halinde cezasını kendisinin vereceğini söyleyen 40 kişinin; \%42,5'inin adli birimlere tanık, şüpheli ve müşteki sıfatı ile temas ettikleri, 
\%77,5'inin adli birimlere gitmeleri halinde kendilerini ifade edebileceklerine inandıkları, \%55'inin adli birimlere müracaat etme kararını kendilerinin aldıkları, \%77,5'inin Türk ile uyuşmazlık yaşamaları halinde adli sürecin kendilerine adil davranmayacağına inandıkları, \%42,5'inin bir yabancı ile uyuşmazlık yaşamaları halinde adli birimlerin kendilerine adil davranmayacağına inandıkları, $\% 45$ 'inin başka bir yabancının suçlarından dolayı kendilerine adli birimlerin olumsuz tavır alacaklarına inandikları, \%77,5'inin geldikleri yerde serbest olmasına karşın Türkiye'de suç olan fiiller/davranışlar olduğunu düşündüğü, \%82'sinin Türkiye'de kendini güvende hissettiği fakat \%62,5'inin yabancılar veya Türkler tarafından suç mağduru olma korkusu yaşadığı ve \%62,5'inin yabancılara karşı toplumsal bir tepki ile karşılaşıldığında devletin kendilerini koruyamayacağına inandıkları fakat her şeye rağmen \%52'sinin firsatı olması halinde Türkiye'de kalmak istedikleri anlaşılmaktadır.

Yakalanma Endişelerinin Değerlendirilmesi: Yabancıların \%37,77'si bir suça karışan yabancının teslim olmayacağına inanmaktadır. Yine yabancıların \%25,77'si kaçmak isteyen bir yabancının yakalanmamak istemesi halinde yakalanmasının mümkün olmadığına inanmaktadır. Yabancılar arasında suça karışan her 10 yabancıdan yaklaşık 4'ünün teslim olmayacağı ve teslim olmayan 4 kişiden 1'ininde kaçması halinde yakalanmasının mümkün olmadığına inanıldığı görülmektedir. $\mathrm{Bu}$ durumda adli birimlere intikal etmiş bir suça karışan her 10 yabancıdan 1 'inin yakalanamayacağının düşünüldüğü görülmekte olup yakalanma endişesinin yaklaşı olarak 10 da 1 olduğu anlaşılmaktadır.

\section{Yabancıların Toplumsal Adalet Algılarına İlişkin Verilerinin Değerlendirilmesi:}

Bilindiği gibi adaletin sade kurumsal/biçimsel yönü bulunmamakta aynı zamanda toplumsal yanı da bulunmaktadır. Toplumu oluşturan tüm bileşenlerin, içinde yaşanılan toplumun 'vicdanına/adalet duygusunda' olan ortak inanc1 ve toplumun muhtemel tavir alma olasılıklarına ilişkin algısı toplumsal düzenin uyum içinde sürdürülebilirliliği bakımdan hayatidir. Dolayısı ile ulaştıkları sayı bakımından neredeyse etnik bir azınlık durumunda olan yabancı uyrukluların 'içinde yaşadıkları toplumun ne düşündüğü ve nasıl davranacağı' konusundaki kanaatleri aslında kendi düşünceleri ve tavır alışlarını belirleyecektir.

Başka sığınmacıların suçlardan dolayı Türk toplumu size karşı tavır alabilir mi? Sorusuna örneklemin tümünün \% 57,33'ü evet derken \% 42,66'sı ise hayır cevabını vermiştir. Dolayısı ile her iki yabancıdan en az birinin toplumun adalet duygusuna güvenmediği görülmektedir. Görüldüğü gibi ülkemizdeki yabacılar büyük oranda Türk toplumunun işlenilen suçun sorumlusu olarak faile değil tüm yabancılara tavır alacağını düşünmektedir.

'Başka sığınmacıların suçlarından dolayı Adli birimler size karşı tavır alabilir mi?' sorusunda tüm örneklemin \%68'i adli birimlerin olumsuz bir tavır almayacağına inanırken sadece \% 32'si adli birimlerin olumsuz bir tavır alacağına inanmaktadır.

Her ne kadar yabancilar arasında toplumsal adalete güvenmeyenlerin oranının\%57,33, kurumsal adalete güvenmeyenlerin oranının $\% 32$ olması oldukça yüksek olsa bile, yabancıların adalete olan güvencinin merkezinde kurumsal adalet olduğu anlaşılmaktadır. Yabancıların, ev sahibi toplumdan ziyade kurumsal adalet mekanizmasını bir güvence olarak algıladıkları görülmektedir. Dolayısı ile yabancılara yönelik adli birimlerin alacakları 'adalet algısını zedeleyen kararlar' aynı zamanda toplumun bir bileşeni olan yabancıları toplum içinde de kararsızlaştıracak ve toplumsal uyumu direk etkileyecektir.

Adli konularda Türk toplumuna güven duymayan yabancıların (258 kişinin) uyruklarına baktığımızda ${ }^{5}$ sırası ile Rusya \%84,61, Suriye \%72,54, Afganistan \%67,71, Misır \%57,14, İran \%55,38, Irak \%43,75, S. Arabistan \%30,43 olduğu görülmektedir. Yabancıların çoğunun ya Suriyeli ya Afgan olduğu düşünüldüğünde bu grup içinde \%70'ler civarında olan güvensizliğin çok büyük bir oran olduğu görülecektir. $\mathrm{Bu}$ kişilerin (258 kişinin) cinsiyet dağılım oranları ise \%40,69 erkek iken \%58,91 kadın olduğu görülmektedir. Kadınların adli konulardaki toplumsal güvensizliğinin daha fazla olduğu anlaşılmaktadır. Yaş dağılımlarında ise bahsedilen bağlamda topluma güven duymayanların (258 kişinin) $\% 33,72$ 'sinin 26-35 yaş, \%22,48'inin 36-45 yaş, $\% 21,7$ 'sinin $15-25$ yaş, \%13,17'sinin 46-55 yaş, \%8.91'inin $56+$ yaş grubunda oldukları görülmektedir. Yabancılardaki toplumsal güvensizliğin 35 yaşına kadar arttığı 35 yaşından sonra bu durumun toplumsal güven lehine azaldığı anlaşılmaktadır.

Eğitim durumların bakıldığında okulsuz olanların (46 kişinin) \%73,91'i, ilkokul mezunu olanların (78 kişinin) $\% 55,15$, lisans mezunu olanların (135 kişinin) \%49,62, lisansüstü mezunu olanların \%60'1 toplumun adli konulardaki reflekslerine güvenmemektedir.

Aylık gelirleri baz alındığında ise alt gelirlilerin (207 kişinin) \%60,86'sının, orta gelirlilerin (146 kişinin) $\% 60,27$ 'si, üst gelirlilerin ise (97 kişinin) 45,36'sının toplumsal adalet duygusuna güvenmedikleri görülmektedir. Eğitim ve aylık gelirin yaşanılan toplumsal güvensizlik duygusunda anlamlı bir etkisinin olmadığı anlaşılmaktadır.

Türkiye'de geçirilen süre baz alındığında 1 gün-1 yıl arası bulunanların (143 kişinin) \%44,05'inin, 2-3 y1l aras1 bulunanların (182 kişinin) \%60,98'inin, 4-5 y1l arası bulunanların (94 kişinin) \%65,95'inin, 6 yıl ve üzeri bulunanların (31 kişinin) \%70,96'sının toplumsal güvensizlik yaşadıkları görülmektedir. Dolayısı ile ülkede kalma süreleri arttıkça yabancıların hissettiği toplumsal tedirginliğin arttığı anlaşılmaktadır.

Tüm bu kötümser algılara karşın başka sığınmacıların işlediği suçlardan dolayı toplumun kendisine tavır alacağını düşünenlerin (258 kişinin) \%20,15'i ülke vatandaşlarının kendisini mağdur edeceğinden korktuklarını, \% 91,47'si Türkiye'de kendilerini güvende hissettiklerini, $\% 67,05$ 'i fırsatı olması halinde Türkiye'de kalacaklarını ifade etmektedirler. Dolayısı ile yabanciların son tahlilde Türkiye'yi güvenli buldukları fakat toplumun muhtemel tepkilerine karşı azımsanmayacak bir oranda tedirginlik yaşadıkları yine de Türkiye'de yaşamak arzularını korudukları anlaşılmaktadır.

\footnotetext{
${ }^{5}$ Ankete katılımları 10 kişinin altında olan menşe ülkeler sıralamaya dâhil edilmemiştir.
} 
Tüm örneklem baz alındığında yabancıların \%20'sinin suç mağduru olmaktan korktukları görülmektedir. Bu \%20'lik dilimin \%15'ini ülke vatandaşlarının kendisini mağdur edeceğinden korkan yabancılar, \%5'ini ise farklı yabancıların kendisini mağdur edeceğinden korkan yabancılar oluşturmaktadır. Her 20 yabancıdan 4'ünün bir suçun mağduru olma tedirginliği ile günlük yaşamlarını sürdürdükleri anlaşılmaktadır. Mağduriyet tedirginliği yaşayan 4 kişiden 3 'ünün ise ülke vatandaşlarından, 1'inin ise yabancılardan korktuğu anlaşılmaktadır.

Suç mağduru olma korkusu yaşayanların (90 kişinin) \%78,88'i Türkiye'de kendilerini güvende hissettiklerini söylerken \%43,33'ü yabancılara yönelik toplumsal bir tepkinin oluşması durumunda devletin kendilerini koruyamayacağına inanmaktadır. Hem suç mağduru olma korkusu yaşayan hem de adli sürecin adil olmadığına inanırsam cezasını kendim veririm diyenlerin tüm örneklem içindeki oranı \%5,5'dir. Dolayısı ile suç korkusu yaşayan kişilerin ihkakı hak eğilimlerinin oldukça düşük olduğu mağdur olmaları durumunda adli birimlere itimat edildiği anlaşılmaktadır.

Son tahlilde 'Türkiye'de kendinizi güvende hissediyor musunuz?' sorusuna örneklemin $\% 93,33$ evet derken $\% 6,66$ ise hayır cevabını verdiği ve 'Fırsatınız olsa Türkiye'de kalır misinız?' Sorusuna \% 69,77 evet, \% 29,77 hayır derken sadece \% 0,44 cevap vermediği görülmektedir.

\section{Sonuç}

Verilerin yorumlanmasında değinilen hususlara, her ne kadar işaret edilmeye değer olsalar bile, mükerrer olmaması bakımından bu bölümde yer verilmemiştir.

Çalışmanın sonunda, Baker ve Tsuda (2015) göçün hedef ülkede sosyal, ekonomik ve kültürel bozulmaya işaret eden faktörlerden ilkinin (göç akışının hızı, boyutu, süresi, sıklığı ve göçmen tipi), Castles ve Miller'in (2008) bahsettiği anlamda'etnik azınlık' yaratacak boyutta gerçekleştiği; ikinci faktör olan ev sahibi toplumun dayanıklılığının azalması durumunun yabancilar tarafindan bile algılandığ anlaşılmıştır.

Bir yandan mevcut durumun yabancılar için memnuniyet verici olduğu fakat toplumda giderek artan yabanc1 karşıtlığını (ev sahibi toplumun azalan dayanıklılığını) hissettikleri buna karşın genel olarak adli birimlere ve devlete güven duydukları anlaşılmıştır. Diğer yandan ise yabancılar içinde toplumsal bir tepkiden korkan, adli birimlere ve adli sürece güvenmeyen, devletin kendisini koruyamayacağına inandığı ve yakalanma ihtimalini az gördüğü için fevri davranacak bir grubun var olduğu anlaşılmıştır.

Yabancıların, toplumun adalet anlayışından/vicdanından ziyade devlete ve kurumlarına (göç yönetimi) güvendikleri anlaşılmıştır. Dolayısı ile yabancıların devlete olan inancını kaybettirecek durumların toplumsal yansımaları olacaktır. Yabancılar nazarında devletin/göç yönetiminin itibar kaybetmesi aynı zamanda ev sahibi topluma karşı olan güvensizliği besleyecek ve içlerindeki fevri davranabilecek grubu büyütecektir. Her ne kadar bu çalışma ev sahibi toplumu kapsamasa bile benzer bir durumun ev sahibi toplum nezdinde de benzer bir sonuç yaratacağı açıktır.
Dolayısı ile ev sahibi ve yabancı toplumun, sonucu göç yönetiminin belirleyeceği bir eşikte durduğu görülmektedir. Ev sahibi toplumun ve devletin 1980'lerde tanışılan görünür göçmenlerin artık farklı bir bağlama evirildiğinin ayırdına varması ve bu realiteye uygun tavır alması gerektiği anlaşılmaktadır.

Yabancilar sorununa 1980 sonrası başlayan görünür göçmen olgusu için geliştirilen (kolluk marifeti ile deport edilir ve sorun biter vb.) çözüm refleksleri üzerinden yaklaşmak yeni bir azınlık sorunu yaratmak potansiyeli taşımaktadır. Çünkü gelinen noktada sorun ev sahibi ve göçmen sorunu değil egemen toplum ve etnik/kültürel azınlık sorunudur. Sorun çözücü ise toplumsal ve kurumsal adalet mekanizmasıdır.

\section{Kaynakça}

Arınç K., (2018),Doğu Sınırlarından Türkiye'ye Yaya Mülteci Akını ve Ortaya Çıkan Sorunlar, Atatürk Üniversitesi Sosyal Bilimler Enstitüsü Dergisi Eylül 2018 22(3), 14671485 .

Aktaş M., (2015), Türkiye'nin Göç Politikası ve Göçmenlerin Sorunları, Disiplinler Arası Göç ve Göç Politikaları Sempozyumu, İstanbul Sebahattin Zaim Üniversitesi, İstanbul, s: 27-44.

Aydın A. H. \& Durgun S., (2018), Kahramanmaraş’taki Suriyeli Sığınmacıların Yerel Halk Tarafindan Sosyo-Ekonomik ve Politik Açıdan Değerlendirilmesi, KSÜSBD, Cilt: 15 Say1:2, 501-526.

Balkır C.\& Kaiser B., (2015), Türkiye'de Avrupa Birliği Vatandaşları, (Der)M. Murat Erdoğan, Ayhan Kaya, Türkiye'nin Göç Tarihi, Bilgi Üniversitesi Yayınları, 223241.

Baker, B. J. \&Tsuda, T., (2015), Bridging The Past And Present İn Assessing Migration,(Edi) Brenda J. B., TakeyukiT., Migration and Disruptions Toward A Unifying Theory Of Ancient And Contemporary Migrations, University Press of Florida,3-14.

Baş T., (2006), Anket Nasıl Hazırlanır Uygulanır Değerlendirilir?, Seçkin Yayınları, Ankara.

Bekerman, Z. \&Geisen T., (2011),International Handbook of Migration, Minorities and Education Understanding Cultural And Social Differences İn Processes Of Learning. Springer.

Bralo, Z. \& Morrison J, (2005), Immigrants, Refugees and Racism Europeans And Their Denial, (Edi) Elspeth G.,Joannevan S., International Migration and Security, Routledge, Oxon.113- 128.

Castles, S. \&Miller M. J., (2008), Göçler Çağı, (çev)Bülent Uğur Bal, İbrahim Akbulut, İstanbul Bilgi Üniversitesi Yayınları.

Ciğerci N., (2016), Bursa-Kırcaali Hattı: 1989'da Gelen Bulgaristan Göçmenleri Örneği, (Der)G. İ. Öner Ve N. A. Ş. Öner., Küreselleşme Çağında Göç Kavramlar, Tartışmalar, İletişim Yayınları, 107-134.

Duruel, M., (2017), Suriyeli Sığınmacıların Karşılaştıkları Temel Sorunlar, Alg1 ve Beklentiler: Hatay Örneği, Akademik Baklş Dergisi, Sayı: 62 Temmuz- Ağustos, 57-79.

Düvell, F., (2006), Reframing the 1rregular Migration Dilemma, Franck Düvell (Edi.), Illegalimmigration In Europe Beyond Control, Palgra - Macmillan UK. 223- 268. 
Erdoğan M. Murat, (2015), Türkiye'ye Kitlesel Göçlerde Son Ve Dev Dalga: Suriyeliler,(Der) M. M. Erdoğan, A. Kaya, Türkiye'nin Göç Tarihi, Bilgi Üniversitesi Yayınları, 317347.

Erdoğan M. M., (2016), Türkiye'deki Suriyeli Mülteciler İle Yaşamanın Çerçevesi,(Edi) A. Esen, M. Duman, , Türkiye'de Geçici Koruma Altındaki Suriyeliler: Tespitler Ve Öneriler, WALD Vakfı Yayınları, İstanbul, 69-88.

Esen, A., (2016), Uluslararası Düzensiz Göçler Ve Yerel Yönetimler, (Edi)A. Esen, M. Duman, , Türkiye'de Geçici Koruma Altındaki Suriyeliler: Tespitler Ve Öneriler, WALD Vakfi Yayınları, İstanbul, 11-41.

Goc.Gov.Tr/İkamet-İzinleri

Goc.Gov.Tr/Duzensiz-Goc-İstatistikler

Goc.Gov.Tr/Uluslarararsi-Koruma-İstatistikler

Goc.Gov.Tr/Gecici-Koruma5638

Guild, E.,Immigrants and the Legal Expression Of National Identity, (Edi) E.Guild, J.S., International Migration And Security, Routledge, Oxon, 101- 112.

Hurriyet.Com.Tr/Gundem/Cinli-Sanip-Korelilere-Saldirdilar29460272 (Erişim Tarihi 14.10.2019)

İçduygu A., Erder S., Gençkaya Ö. F., (2014), Türkiye'nin Uluslararası Göç Politikaları 1923-2023: Ulus-Devlet Oluşumundan Ulus-Ötesi Dönüşümlere, Koç Üniversitesi Göç Araştırmaları Merkezi, İstanbul.

İskan Kanunu, 1934, Kanun No:2510

İskan Kanunu, 2006, Kanun No:5543

İOM, 2019. https://www.iom.int/who-is-a-migrant (Erişim Tarihi:17.09.2019)

İOM, 2018a, Global Migration Indicators, https://publications.iom.int/system/files/pdf/global_migrati on_indicators_2018.pdf (Erişim Tarihi:17.09.2019)

İOM, 2018b,World Migration Report, https://www.iom.int/sites/default/files/country/docs/china/ r5_world_migration_report_2018_en.pdf (Erişim Tarihi:17.09.2019)

Kamp Dışında Yaşayan Suriyeli Sığınmacılar İçin Durum Analiz Raporu, (2013), Concern World Wide, (mavikalem.org/wp-content/uploads/durum-analızısurıyel1-sıgınmacılar_sanlıurfa-2013-pdf Erişim Tarihi: 14.10.2019)

Karaca S., DOĞAN U., (2014), Suriyeli Göçmenlerin Sorunları Çalıştay Raporu, Bölgesel İzleme Uygulama Araştırma Merkezi, Mersin Üniversitesi,

Karasu M. A.,(2017), Türkiye'deki Suriyeli Sığınmacıların Kentlerde Neden Oldukları Güvenlik Riskleri, Hacettepe Üniversitesi İktisadi Ve İdari Bilimler Fakültesi Dergisi,Cilt 36, Say1 2, 2018, 51-73.

Karpat K., (2015), Önsöz, M. Murat Erdoğan, Ayhan Kaya (Der), Türkiye'nin Göç Tarihi, Bilgi Üniversitesi Yayınları, Xxv$\mathrm{Xl}$.

Kaya A.\& Erdoğan M. M., (2015), Giriş,(Der)M. M. Erdoğan, A. Kaya, Türkiye’nin Göç Tarihi, Bilgi Üniversitesi Yayınlar1, 3-14.

Kızmaz Z., (2018), Suriyeli Sığınmacılar: Güvenlik Kaygıları ve Suç, Bitlis Eren Üniversitesi Sosyal Bilimler Enstitüsü Dergisi, Cilt:7, Say1:2, 392-431.

Kirişçi K. \& Karaca S., (2015), Hoşgörü ve Çelişkiler: 1989,1991 Ve 2011'de Türkiye'ye Yönelen Kitlesel Mülteci Akınları,
M. Murat Erdoğan, Ayhan Kaya (Der),Türkiye'nin Göç Tarihi, Bilgi Üniversitesi Yayınları, 297-314.

Khalid K., (2007), International Migration: A Very Short Introduction, Oxford University Press,

Kümbetoğlu B., (2008), Sosyolojide ve Antropolojide Niteliksel Yöntem ve Araştırma, Bağlam Yayınları, Ankara.

Massey, D. S.,Arango, J., Hugo, G., Kouaouci, A., Pellegrino, A. T., Edward J., (1998). Worlds İn Motion: Understanding International Migration At The end Of The Millennium. Oxford: Clarendon Press.

OECD, (2018), International Migration Outlook

ORSAM,(2015), Suriyeli Sı̆̆ınmacıların Türkiye'ye Etkileri, (Orsam.Org.Tr/Suriyeli-Siginmacilerin-Turkiye-YeEtkileri/ Erişim Tarihi:14.10.2019)

Özgür N.,(2016), Modern Türkiye'nin Zorunlu Göçmenleri: Muhacirler, İskanlılar, Mübadiller, İslamlar, Soydaşlar, G Grubu, Mülteciler, Tekne Mültecileri, (Der)G. İ. Öner Ve N. A. Ş. Öner., Küreselleşme Çağında Göç Kavramlar, Tartışmalar, İletişim Yayınları, 199-216.

Özkul, D.,(2016),Ulus Ötesi Göç: Uluslararası Göç Yazınında Yeni Bir Paradigma,Der). G. İ. Öner Ve N. A. Ş. Öner,Küreselleşme Çağında Göç Kavramlar, Tartışmalar, İletişim Yayınları. 483-500.

Perruchoud, R.\&Redpath- Cross, J., (2013), Göç Terimleri Sözlüğü, Uluslararası Göç Örgütü.

Sağıroğlu A. Z., (2016), Türkiye'de Merkezi Göç Yönetimi, (Edi) A. Esen, M. Duman, Türkiye'de Geçici Koruma Altındaki Suriyeliler: Tespitler ve Öneriler, WALD Vakfi Yayınları, İstanbul 43-68.

Sert,D. Ş., (2016),Uluslar Arası Göç Yazımında Bütünleyici Bir Kurama Doğru, (Der.) G. İ. Öner Ve N. A. Ş. Öner,Küreselleşme Çağında Göç Kavramlar, Tartışmalar, İletişim Yayınları, 29-47.

Solimano A., (2010), International Migration İn The Age Of Crisis And Globalization Historical And Recent Experiences, Cambridge University Press.

Tsuda T.,Brenda J. B., James F. E., Kelly J. K., Jonathan M., Lisa M., Rachel E. S., (2015), Unifying Themes İn Studies Of Ancient And Contemporary Migrations, (Edi.) Brenda J. B.,TakeyukiT.,Migration And Disruptions Toward A Unifying Theory Of Ancient And Contemporary Migrations, University Press Of Florida, 15- 30.

Tsuda T. \& Brenda J. B., (2015), Migration And Disruptions From Prehistory To The Present, (Edi.) Brenda J. B., Takeyuki T., Migration And Disruptions Toward A Unifying Theory Of Ancient And Contemporary Migrations, University Press Of Florida, 296-331.

Tsuda T., (2015), Unequal İn The Court Of Public Opinion Mexican And Asian Immigrant Disruptions İn The United States, (Edi.) Brenda J. B.,TakeyukiT., Migration And Disruptions Toward A Unifying Theory Of Ancient And Contemporary Migrations, University Press Of Florida. 243-270.

UN, (2018),Report Of The Secretary General On The Work Of The Organization https://www.un.org/annualreport/pdf/en/full_report.pdf (Erişim Tarihi:17.09.2019)

World Migration Report, (2018), International Organization For Migration, Switzerland.

Yıldırım A.\& Ve Şimşek H., (2005), Sosyal Bilimlerde Nitel Araştırma Yöntemleri, Seçkin Yayınları, Ankara. 